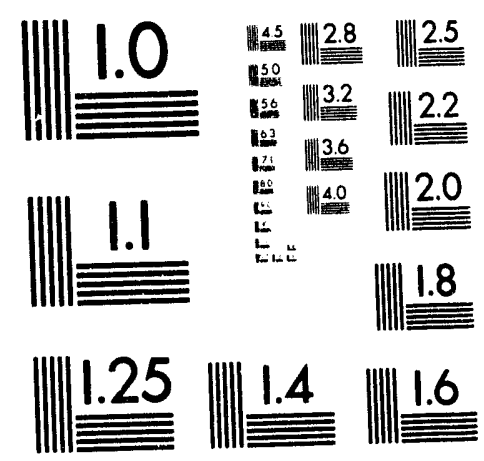



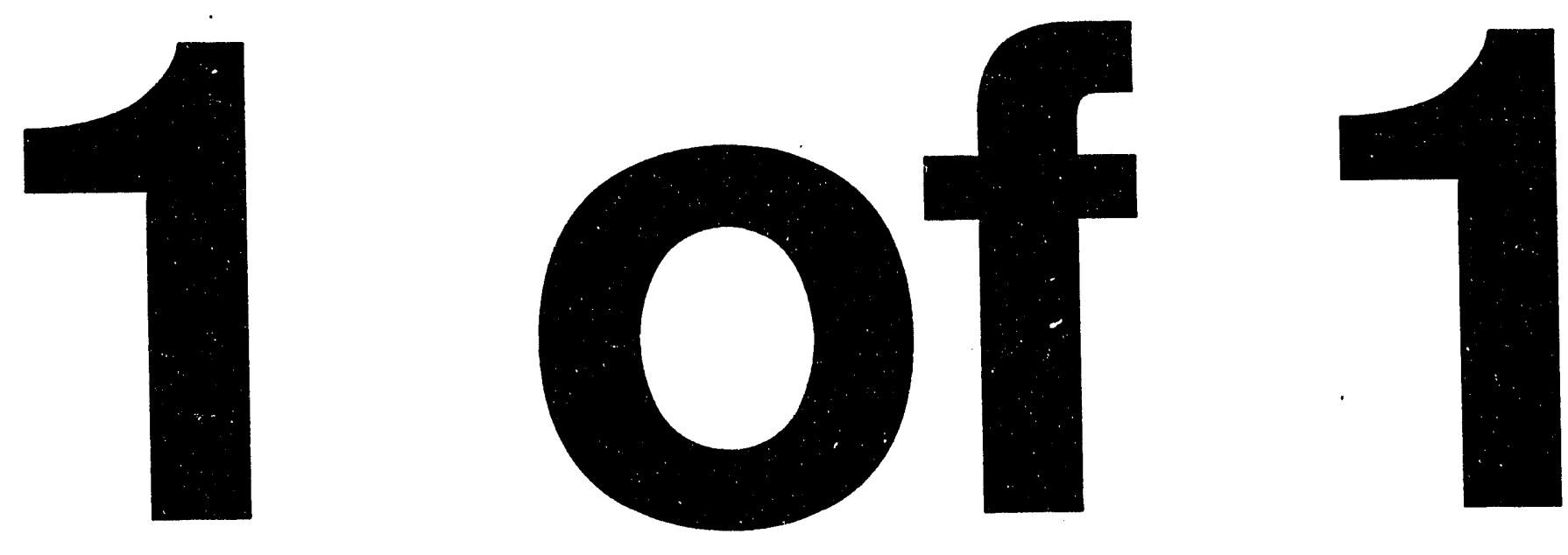
NUREG/CR-6073

EGG-2706

$\mathrm{CC}, \mathrm{CJ}, \mathrm{CO}, \mathrm{CY}, \mathrm{RW}$

\section{Lysimeter Literature Review}

Manuscript Completed: July 1993

Date Published: August 1993

Prepared by

R. D. Rogers, J. W. McConnell, Jr.

Idaho National Engineering Laboratory

Managed by the U.S. Department of Energy

EG\&G Idaho, Inc.

Idaho Falls, ID 83415

\section{Prepared for}

Division of Regulatory Applications

Office of Nuclear Regulatory Research

U.S. Nuclear Regulatory Commission

Washington, DC 20555-0001

NRC FIN A6876

Under DOE Contract No. DE-AC07-76ID01570 


\section{DISCLAIMER}

NUREG/CR-6073 is not a substitute for NRC regulations and compliance is not required. The approaches and/or methods described in this NUREG/CR are provided for information only. Publication of this report does not necessarily constitute NRC approval or agreement with the information contained herein. 


\begin{abstract}
Many reports have been published concerning the use of lysimeters to obtain data on the performance of buried radioactive waste. This document presents a review of the pertinent reports. This review includes lysimeter studies using radioactive waste forms at the Savannah River Site, Hanford Site by Pacific Northwest Laboratory (PNL), Argonne National Laboratory, and Oak Ridge National Laboratory; radionuclide tracer studies at Whiteshell Nuclear Research Establishment and Los Alamos National Laboratory; and water movement studies at the Nuclear Regulatory Commission's Beltsville, Maryland site, at the Hanford Site by PNL, and at New Mexico State University. A description of the tests, results, and conclusions of each report are summarized, and conclusions concerning lysimeter technology are presented from an overall analysis of the literature.
\end{abstract}

FIN No. A6876-Field Lysimeter Investigations:

Low-Level Waste Data Base Development Program 


\section{CONTENTS}

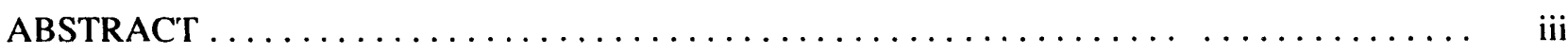

LIST OF FIGURES $\ldots \ldots \ldots \ldots \ldots \ldots \ldots \ldots \ldots \ldots \ldots \ldots \ldots \ldots \ldots \ldots \ldots \ldots$

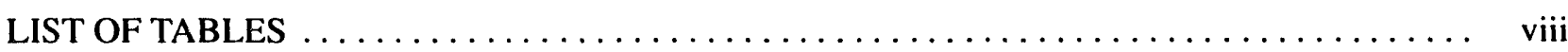

EXECUTIVE SUMMARY $\ldots \ldots \ldots \ldots \ldots \ldots \ldots \ldots \ldots \ldots \ldots \ldots \ldots \ldots \ldots \ldots \ldots \ldots \ldots \ldots$

ACRONYMS $\ldots \ldots \ldots \ldots \ldots \ldots \ldots \ldots \ldots \ldots \ldots \ldots \ldots \ldots \ldots \ldots \ldots \ldots \ldots \ldots \ldots \ldots$

INTRODUCTION $\ldots \ldots \ldots \ldots \ldots \ldots \ldots \ldots \ldots \ldots \ldots \ldots \ldots \ldots \ldots \ldots \ldots \ldots \ldots$

STUDIES OF LYSIMETERS CONTAINING RADIOACTIVE WASTE FORMS $\ldots \ldots \ldots \ldots$

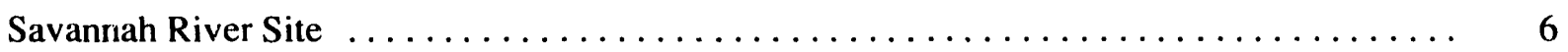

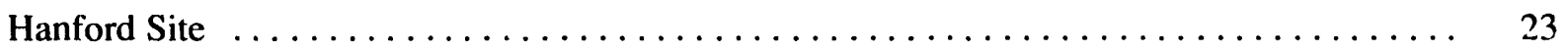

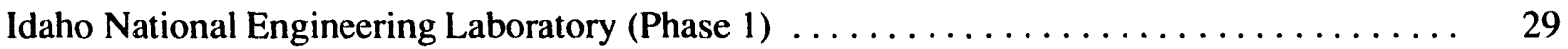

Idaho National Engineering Laboratory $($ Phase 2$) \ldots \ldots \ldots \ldots \ldots \ldots \ldots \ldots \ldots \ldots \ldots \ldots$

Oak Ridge National Laboratory $\ldots \ldots \ldots \ldots \ldots \ldots \ldots \ldots \ldots \ldots \ldots \ldots \ldots \ldots \ldots \ldots \ldots$

RADIONUCLIDE TRACER STUDIES $\ldots \ldots \ldots \ldots \ldots \ldots \ldots \ldots \ldots \ldots \ldots \ldots \ldots \ldots \ldots$

Whiteshell Nuclear Research Establishment $\ldots \ldots \ldots \ldots \ldots \ldots \ldots \ldots \ldots \ldots \ldots \ldots$

Los Alamos National Laboratory $\ldots \ldots \ldots \ldots \ldots \ldots \ldots \ldots \ldots \ldots \ldots \ldots \ldots \ldots \ldots \ldots$

WATER MOVEMENT STUDIES $\ldots \ldots \ldots \ldots \ldots \ldots \ldots \ldots \ldots \ldots \ldots \ldots \ldots \ldots \ldots \ldots \ldots$

Bioengineering Management Lysimeters $\ldots \ldots \ldots \ldots \ldots \ldots \ldots \ldots \ldots \ldots \ldots \ldots \ldots$

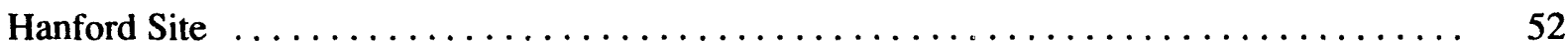

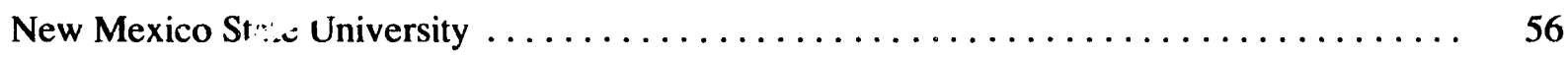

CONCLUSIONS $\ldots \ldots \ldots \ldots \ldots \ldots \ldots \ldots \ldots \ldots \ldots \ldots \ldots \ldots \ldots \ldots \ldots \ldots \ldots \ldots \ldots \ldots$

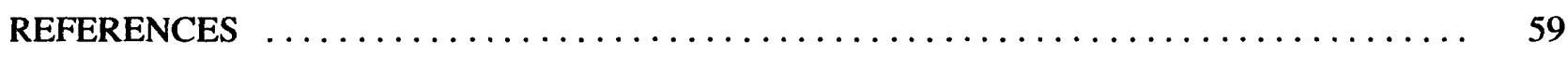




\section{LIST OF FIGURES}

1. Location of Savannah River Site lysimeter facilities $\ldots \ldots \ldots \ldots \ldots \ldots \ldots \ldots \ldots \ldots$

2. Location and waste type in the Defense Waste Lysimeter Facility $\ldots \ldots \ldots \ldots \ldots \ldots \ldots$

3. Cross section of SRS defense waste lysimeter $\ldots \ldots \ldots \ldots \ldots \ldots \ldots \ldots \ldots \ldots \ldots$

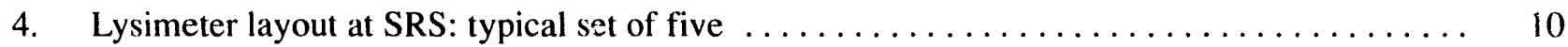

5. Diagram of SRS special waste form lysimeter $(1.8 \mathrm{~m} \times 3.5 \mathrm{~m})$ fiberglass tank $\ldots \ldots \ldots \ldots 14$

6. Arrangement of special waste form lysimeters in the SRS burial ground $\ldots \ldots \ldots \ldots \ldots$

7. Cumulative Co-60 of lysimeter 41 from SRS special waste form lysimeter $\ldots \ldots \ldots \ldots$

8. Cumulative Co-60 of lysimeter 42 from SKS special waste form lysimeter $\ldots \ldots \ldots \ldots \ldots$

9. Cumuldtive $(0-60$ of lysimeter 43 from SRS special waste form lysimeter $\ldots \ldots \ldots \ldots$

10. Cumulative Co-60 of lysimeter 44 from SRS special waste form lysimeter $\ldots \ldots \ldots \ldots$

11. Cumulative Cs-137 of lysimeter 44 from SRS special waste form lysimeter $\ldots \ldots \ldots \ldots$

12. Cumulative Co-60 of lysimeter 46 from SRS special waste form lysimeter $\ldots \ldots \ldots \ldots$

13. Cumulative Co-60 of lysimeter 47 from SRS special waste form lysimeter $\ldots \ldots \ldots \ldots$

14. Cumulative Co-60 of lysimeter 48 from SRS special waste form lysimeter $\ldots \ldots \ldots \ldots \ldots$

15. Cumulative Co-60 of lysimeter 49 from SRS special waste form lysimeter $\ldots \ldots \ldots \ldots$

16. Cumulative Co-60 of lysimeter 51 from SRS special waste form lysimeter $\ldots \ldots \ldots \ldots .20$

17. Cumulative Co-60 of lysimeter 52 from SRS special waste form lysimeter $\ldots \ldots \ldots \ldots .21$

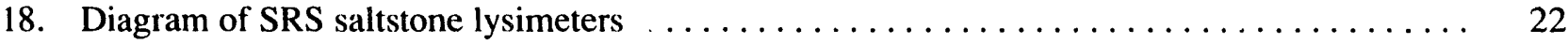

19. Diagram of PNL special waste form lysimeter facility $\ldots \ldots \ldots \ldots \ldots \ldots \ldots \ldots \ldots \ldots$

20. Cumulative Co-60 from PNL special waste form lysimeters $2,3,4,8,9$, and $10 \ldots \ldots 26$

21. Cumulative $\mathrm{H}-3$ from PNL special waste form lysimeters 1 and $7 \ldots \ldots \ldots \ldots$

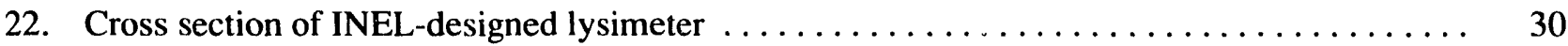

23. Diagram of INEL-designed lysimeter arrays $\ldots \ldots \ldots \ldots \ldots \ldots \ldots \ldots \ldots \ldots \ldots \ldots \ldots$

24. Example of lysimeter soil moisture data from INEL-managed lysimeter array . . . . . . 33

25. Example of lysimeter soil temperature data from INEL-managed lysimeter array $\ldots \ldots \ldots .33$ 
26. Cumulative $\mathrm{Sr}-90$ from moisture cup number 3 at the INEL-managed ANL-E

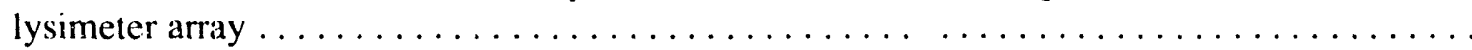

27. Cumulative Sr-90 from moisture cup number 3 at the INEL-managed ORNL

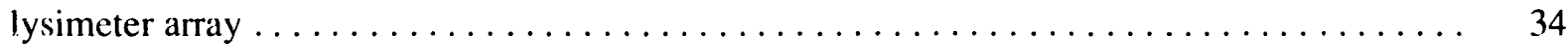

28. Cumulative Sr-90 from leachate water at the INEL-managed A NL-E lysimeter array $\ldots \ldots \ldots$

29. Cumulative $\mathrm{Sr}-90$ from leachate water at the INEL-managed OR:NL lysimeter array ...... 35

30. Cumulative Cs-137 from moisture cup number 3 at the INEL-managed ANL-E

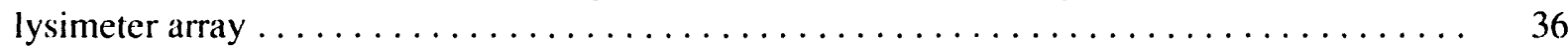

31. Cumulative Cs-137 from moisture cup number 3 at the INEL-managed ORNL

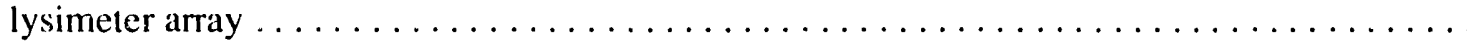

32. Comparison of Cs-137 cumulative activities for measured data at ORNL lysimeter 3

leachate collector $(51.2 \mathrm{~cm}$ of soil) and mixing bath model prediction $\ldots \ldots \ldots \ldots \ldots \ldots$

33. Cumulative release of Sr-90 at ANL-E lysimeter 5 over 6 years, compared with DUST predictions using two sets of estimated $\mathrm{K}_{\mathrm{d}}$ and dispersivity values over 20 years $\ldots \ldots \ldots \ldots$

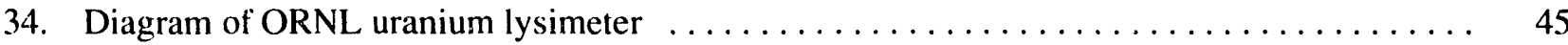

35. Cut-away view of soil core and leachate/groundwater cup assembly $\ldots \ldots \ldots \ldots \ldots \ldots$

36. Diagram of Los Alamos National Laboratory lysimeter $\ldots \ldots \ldots \ldots \ldots \ldots \ldots \ldots \ldots$

37. Diagram of Beltsville bioengineered lysimeter $\ldots \ldots \ldots \ldots \ldots \ldots \ldots \ldots \ldots \ldots \ldots \ldots$

38. Plan view showing placement of lysimeters at Beltsville $\ldots \ldots \ldots \ldots \ldots \ldots \ldots \ldots \ldots \ldots$

39. Diagram of precision weighting lysimeters for evapotranspiration measurements at

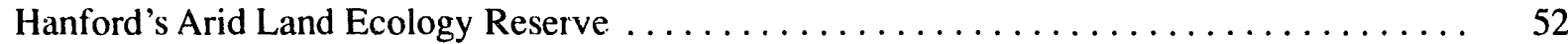

40. Diagram of Field Lysimeter Test Facility at Hanford $\ldots \ldots \ldots \ldots \ldots \ldots \ldots \ldots \ldots \ldots$

41. Diagram of lysimeter placement and vegetation cover at the Field Lysimeter Test Facility . . $\quad 54$

42. Plan view of the Field Lysimeter Test Facility with treatment designations $\ldots \ldots \ldots \ldots \ldots$

43. Diagram of instrument location in Field Lysimeter Test Facility lysimeters $\ldots \ldots \ldots \ldots \ldots$

44. Plan view of trench lysimeter face with irrigated area and neutron probe access tubes ..... 56 


\section{LIST OF TABLES}

1. Reviewed lysimeter studies detailing radionuclides, waste form type, waste class, and

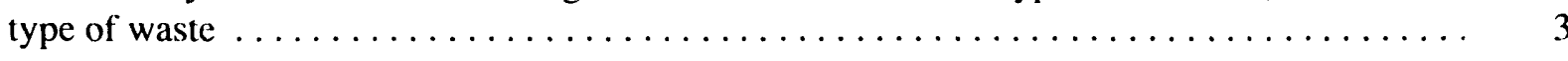

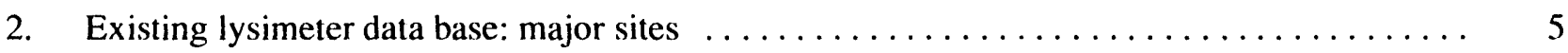

3. Parameters used for SRS transport code $\ldots \ldots \ldots \ldots \ldots \ldots \ldots \ldots \ldots \ldots \ldots \ldots \ldots \ldots \ldots \ldots \ldots \ldots \ldots$

4. Maximum fractional nuclide release rates from SRS defense waste form lysimeters $\ldots \ldots \ldots \quad 13$

5. Chemical and radionuclide composition of decontaminated salt solution $\ldots \ldots \ldots \ldots \ldots \ldots$

6. Total amount of nonradioactive elements leached from PNL special waste form lysimeters .. 28

7. Composition of waste forms for INEL-designed lysimeter arrays $\ldots \ldots \ldots \ldots \ldots \ldots \ldots \ldots$

8. Retardation coefficients $\left(\mathrm{cm}^{3} / \mathrm{g}\right)$ of three soils used in INEL-managed lysimeter arrays $\ldots \ldots \quad 38$

9. Total and collected Ci amounts of Sr-90 and Cs-137 in lysimeter 5 through July $1991 \ldots 39$ 


\section{EXECUTIVE SUMMARY}

Lysimeters are used in field testing because, when properly designed, they can be applied to isolate and manipulate soil systems under actual environmental conditions. Lysimeters have been used in the field for many years to determine the amount of leaching of various elements from soil due to percolation of water. Lysimeters are very useful for testing radioactive waste forms. They provide real-time data that are important because they reflect the current status of the experiment, whereas environmental monitoring data reflect only the results of something that happened in the past. Without current data, it can be impossible for present actions to correct future impacts.

Using lysimeters to test radioactive waste forms has been recognized by the U.S. Nuclear Regulatory Commission (NRC) as a viable and necessary method to develop the source term for performance assessment. The NRC noted that the use of field lysimeters is a necessary research strategy to provide urgently needed data on the leachability of radioactive nuclides, chemicals, and chelating agents from solidified low-level waste (LLW). Extended periods of time ( 10 years or more) are required to obtain a complete set of meaningful data from lysimeter studies. The utility of such a reliable source of data will be demonstrated through continued operation of the lysimeters for a minimum of 20 years, which will provide the capability to predict waste form stability for 300 years and beyond.

A majority of the lysimeters used in the U.S. Department of Energy (DOE) system are for determining the fate of radionuclides in various soil columns. Some, however, have been designed or could be modified to provide those data that could be used to validate modelgenerated predictions or could be used as input to the models.

The Savannah River Site currently operates defense waste, saltstone (large-scale), and slag saltstone lysimeters. Studies using these lysimeters were designed to provide improved radionuclide migration data for assessing the potential long-term hazards from buried radioactive waste. Companion studies that are being conducted at Savannah River Site (moist environment) and at Pacific Northwest Laboratory at the Hanford Site (arid environment) are the special waste form studies. These facilities were developed to study the release of radionuclides from samples of nuclear power station low-level radioactive waste solidified using commercial formulations. Personnel also examined the ability of such studies to predict leaching under field conditions.

Another successful operating system is the NRC Field Lysimeter Program, which consists of arrays of lysimeters installed at Oak Ridge National Laboratory and Argonne National Laboratory-East. The experiment was developed and is managed by the Idaho National Engineering Laboratory. Phase 1 includes field testing of waste forms composed of solidified ion-exchange resin material from EPICOR-II prefilters used in the cleanup of the Three Mile Island Nuclear Power Station. Waste used in the study was significant because of its high loading of radionuclides as well as the use of actual ion-exchange resin wastes of the type used by the nuclear industry. Phase 2 is being developed to quantify radionuclide transport from representative commercial wastes under unsaturated and saturated flow conditions.

A uranium lysimeter demonstration project was begun with support from the Y-12 Plant at Oak Ridge National Laboratory to provide data on how uranium behaves under burial conditions. The study was designed to investigate the leaching characteristics of waste types containing depleted uranium.

Four studies were conducted by the Whiteshell Nuclear Research Establishment for Atomic Energy Canada, Ltd. Three of the studies were conducted to determine to what extent technetium (Tc) moves in soils. The fourth study was conducted to determine the transport of C-14 in soil.

The Experimental Engineered Test Facility was developed at Los Alamos National 
Laboratory to evaluate leaching and transport of solutes in a sandy silt backfill used for shallow land burial operations at Los Alamos. Movement in such material can be under saturated or unsaturated conditions. The purpose of the study was to provide data to develop a capability to predict chemical transport under unsaturated conditions. Lysimeter-scale studies ather than laboratoryscale studies were conducted because experiments performed on the larger scale are more representative of large-scale field problems than those performed with small columns.

The bioengineering management study at Beltsville, Maryland utilizes a combination of engineered enhanced run-off and stressed vegetation in an overdraft condition to control deep water percolation through disposal unit covers. The concept is that vegetation planted between areas of an impermeable cover will intercept incoming solar energy and promote evapotranspiration. Roots that will extend under the cover in all directions will remove water from the soil. Such a system is similar to a supermarket parking lot where trees are planted in islands among an extensive paved area.

Precision-weighing lysimeters were installed to measure variations in evapotranspiration for distinct plant communities at the Hanford Site. Data from the lysimeter system are to be used to develop predictive models of the water-driven processes in arid regions. It is expected that such models will fill a critical role in the management of LLW and hazardous chemical wastes. Also, a field lysimeter test facility was constructed dur- ing FY 1987 at Hanford to test protective barriers for isolating LLW and hazardous wastes from the environment.

A comprehensive field trench study was conducted in semiarid southern New Mexico at New Mexico State University near Las Cruces to provide data to test deterministic and stochastic models of vadose zone flow and transport.

Lysimeters are very useful tools that have been successfully applied by several researchers to the study of radionuclide movement in soils under actual environmental conditions. Lysimeter studies require a long-term commitment in terms of operational longevity and funding. However, their use results in the acquisition of hard-toobtain radionuclide transport data in a costeffective manner. Such information cannot be obtained from artificially accelerated laboratory studies.

Existing NRC lysimeter studies developed and managed by the INEL are utilizing technologies similar to those used by other successful experiments such as the Pacific Northwest Laboratories and Savannah River Site special waste form lysimeters. Also, data from existing NRC radionuclide transport lysimeter experiments are being applied to waste form performance assessments, thus moving the project from observational to predictive. Few existing experiments utilize wastes from commercial power stations. In addition, the important long-lived radionuclides listed in Table 1 of 10 CFR 61 have been seriously investigated by only a few researchers. 


\section{ACRONYMS}

$\begin{array}{llll}\text { AECL } & \text { Atomic Energy Canada, Lid. } & \text { NRC } & \begin{array}{l}\text { U.S. Nuclear Regulatory } \\ \text { Commission }\end{array} \\ \text { ANL-E } & \text { Argonne National Laboratory-East } & \text { NRE } & \text { Nuclear Research Establishment } \\ \text { BNL } & \text { Brookhaven National Laboratory } & \text { NTS } & \text { Nevada Test Site } \\ \text { DAS } & \text { data acquisition system } & \text { OD } & \text { outside diameter } \\ \text { DOE } & \text { U.S. Department of Energy } & \text { ORNL } & \text { Oak Ridge National Laboratory } \\ \text { EETF } & \text { Experimental Engineered Test } & \text { PNL } & \text { Pacific Northwest Laboratory } \\ & \text { Facility } & \text { RFP } & \text { Rocky Flats Plant } \\ \text { ID } & \text { inside diameter } & \text { SRS } & \text { Savannah River Site } \\ \text { INEL } & \text { Idaho National Engineering } & \text { TDR } & \text { time domain reflectometry } \\ & \text { Laboratory } & \text { UC } & \text { University of California } \\ \text { LANL } & \text { Los Alamos National Laboratory } & \text { UM } & \text { University of Maryland } \\ \text { LLW } & \text { low-level waste } & \text { VES } & \text { vinyl ester styrene } \\ \text { NMSU } & \text { New Mexico State University } & \text { WHC } & \text { Westinghouse Hanford Company }\end{array}$




\section{Lysimeter Literature Review}

\section{INTRODUCTION}

Lysimeters are used in field testing because, when properly designed, they can be applied to isolate and manipulate soil systems under actual environmental conditions. Lysimeters have been used in the field for many years to determine the amount of leaching of various elements from soil due to percolation of water. In fact, the word lysimeter comes from the two Greek roots lysi (loosening) and meters (to measure).

The shape and size of lysimeters are determined by the imagination and experimental requirements of the investigator. They can range from small volumes of ficld soil isolated from surrounding areas by impervious dividers to conciete or metal tanks. If tanks are used, they can consist of an upper and lower compartment and are placed into the field so that the open end is level with the soil surface. The upper compartment serves as a containment for soil while the lower level serves as a collection and storage compartment for water that has passed through the overlying soil. Lysimeters without bottom compartments will have some porous media in the bottom such as gravel to separate percolating water from soil.

Lysimeters lend themselves to instrumentation. They can be placed on top of weighing devices so that water content can be determined gravimetrically, and they can have various water sampling, temperature, and moisture-sensing devices implanted as they are filled with soil. The number and type of measuring devices depends on the experimental objectives.

Lysimeters are very useful for testing radioactive waste forms. They provide real-time data (that are varied depending on the type of lysimeter and the array of instrumentation used), which can be used for numerous purposes. Real-time data are important because they reflect the current status of the experiment, whereas environmental monitoring data reflect only the results of something that happened in the past. Without current data, it can be impossible for present actions to correct future impacts.

Using lysimeters to test radioactive waste forms has been recognized by the U.S. Nuclear Regulatory Commission (NRC) as a viable and necessary method to develop the source term for performance assessment. The NRC Low-Level Waste (LLW) Research Program Plan (O'Donnell and Lambert 1989) noted that the use of field lysimeters is a necessary research strategy to provide urgently needed data on the leachability of radioactive nuclides, chemicals, and chelating agents from solidified LLW. Existing experimental results from radioactive lysimeters would be examined, and initiation of new lysimeter tests have been recommended. These new tests would be conducted using typical LLW from commercial nuclear power stations, with emphasis on types of wastes not previously examined, such as decontamination ion-exchange resin and evaporator concentrates solidified in cement and activated metals from light water reactors. Plans are underway to validate performance assessment models by use of a combination of laboratory leaching experiments, trench leachate analysis at LLW disposal sites, and field lysimeter studies. The results of that research program (O'Donnell and Lambert 1989) will be used in the regulation of LLW disposal.

Researchers from Brookhaven National Laboratory (BNL) (Sullivan and Suen 1991) successfully applied lysimeter data to benchmarking of computer codes for the prediction of radionuclide migration in disposal facilities. They recommend the use of the radionuclides C-14, I-129, Tc-99, and $\mathrm{H}-3$ (all mentioned specifically in 10 CFR 61 due to the combination of long half-life and high mobility in soils) in future lysimeter experiments. They also noted that environmental samples should be obtained near a waste form because of limited rates of nuclide release. Additional data are also required from studies on unsaturated soils. 


\section{Introduction}

One of the conclusions from the BNL study was that extended periods of time (10) years or more) are required to obtain a complete set of meaningful data from lysimeter studies. A similar conclusion was reached by researchers at the Idaho Natı nal Engineering Laboratory (INEL) (McConnelt et al. 1990). They pointed out that the data provided by INEL-managed lysimeter experiments had been shown to be usiful as input parameters for performance assessment codes. The utilisy of such a reliable source of data will be demonsirated through continued operation of the lysimeters for a minimum of 20 years. Such a period of time was thought necessary to validate the codes used to provide the capability to predict waste form stability for 300 years and beyond.

Table I lists the lysimeter studies that are reviewed in this report. The list deals primarily with studies that utilized solidified radioactive waste forms. Presented for each experiment reviewed are the radionuclides, waste form iype, waste class, and type of waste. A majority of those lysimeters used in the U.S. Department of Energy (DOE) system are for determining the fate of radionaclides in various soil columns. Table 2 provides a list of known and planned lysimeter studies at several DOE sites. Some, however, have been designed or coule 'e modified to provide those data that could be used to validate model-generated predictions or could be used as input to the models. Data input would serve the purpose of providing "real" data to deal with the uncertainty sometimes surrounding the use of "textbook data" or data back-calculated from environmental monitoring data.

Since 1981, a total of 118 titles on the uses of lysimeters have been published. Of these, $25 \%$ dealt with soil moisture balance studies, $4 \%$ were studies on model validation, $31 \%$ discussed the movemen of organics and metals in soil systems, $19 \%$ were directed toward fate and degradation studies. and the remaining $20 \%$ studied the movement of radionuclides. The purpose of this report is to review some of the pertinent published reports on the use of lysimeters to obtain data on the status of buried radioactive waste. This review includes lysimeter studies using radioactive waste forms at Savannah River Site, Hanford Site, Argonne National Laboratory, and Oak Ridge National Laboratory; radionuclide tracer studies at Whiteshell Nuclear Research Establishment and Los Alamos National Laboratory: and water movement studies at the Nuclear Regulatory Commission's Beltsville, Maryland site, at the Hanford Site, and at New Mexico State University. The tests, results, and conclusions of each report are summarized, and conclusions concerning lysimeter technology are presented from an overall analysis of the literature. 
Introduction

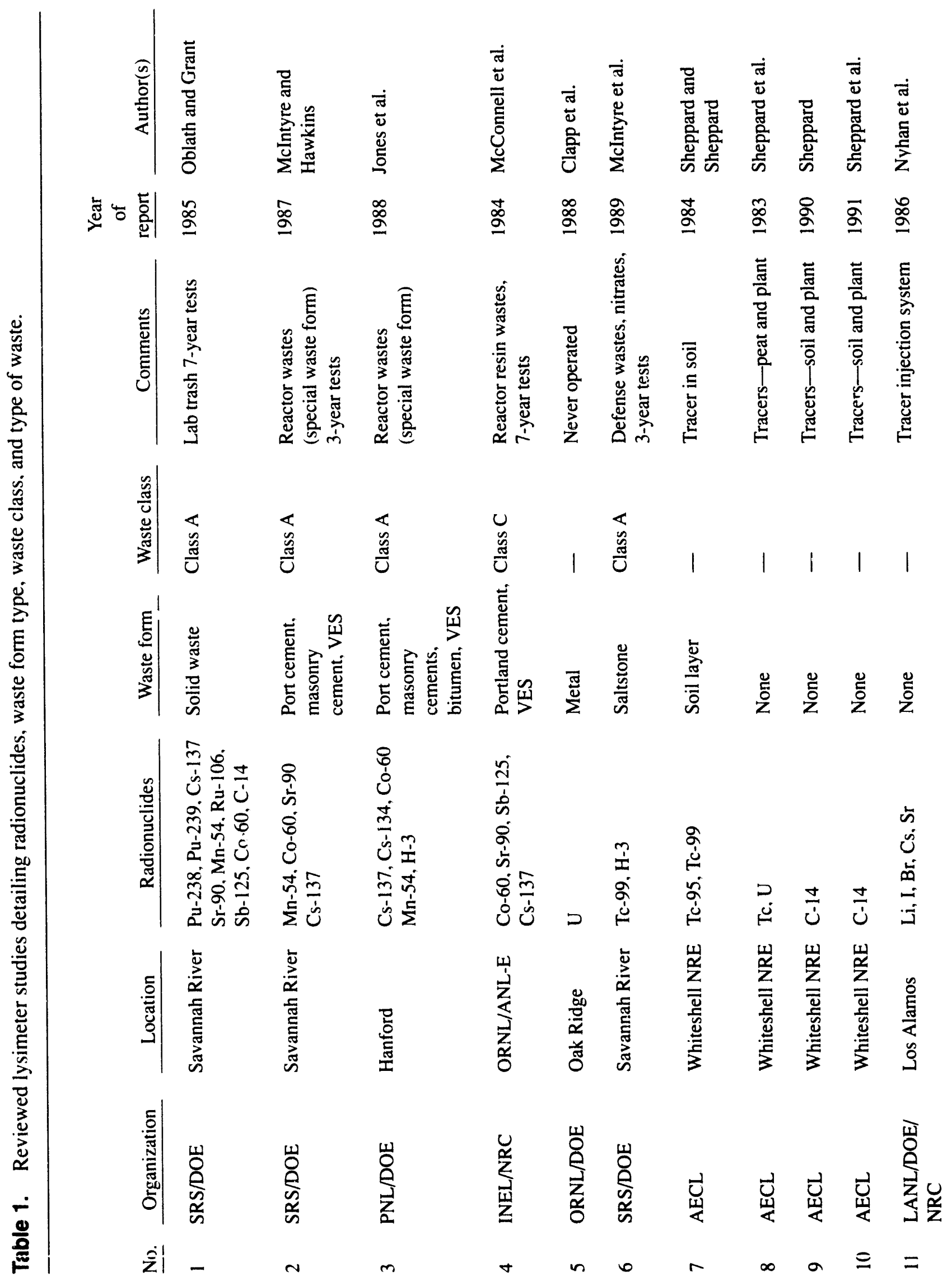


Introduction

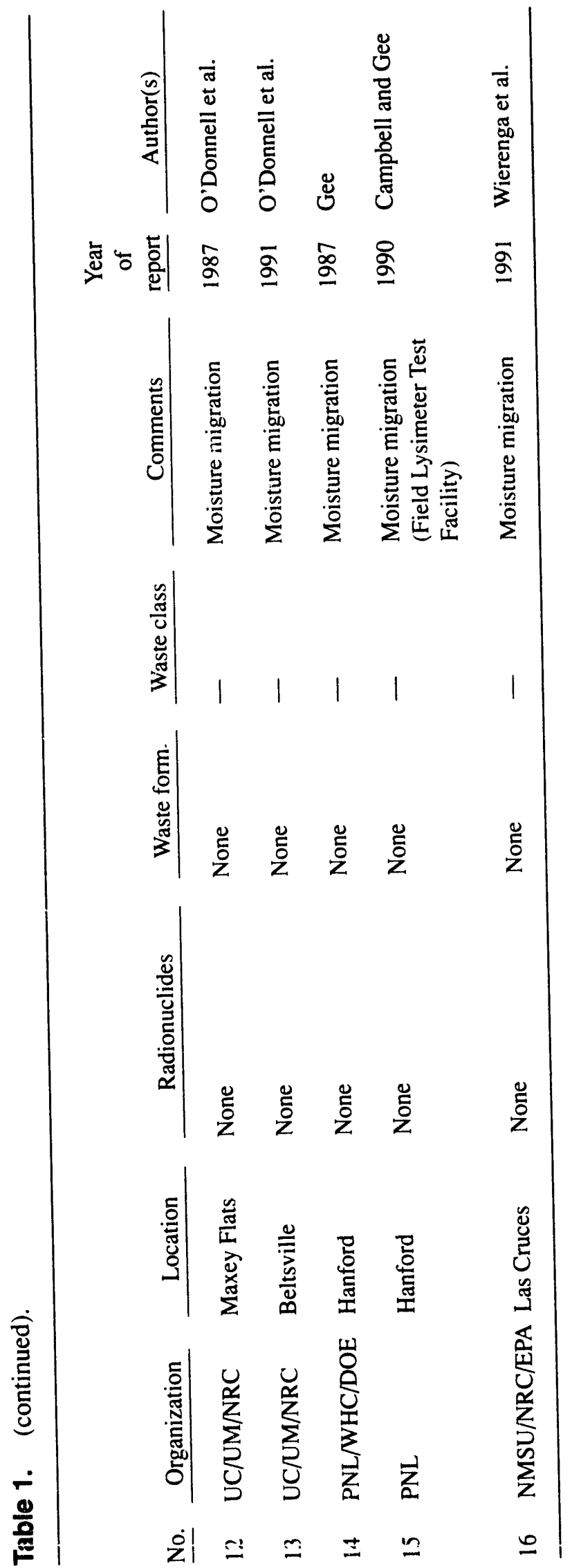


Table 2. Existing lysimeter data base: major sites.

Site

Lysimeter description

LANL

- 2 arrays of 6 around access caisson- $-10 \mathrm{ft}$ diameter $\times 20 \mathrm{ft}$ deep and 6 around access caisson- $1.54 \mathrm{ft}$ diameter $\times 20 \mathrm{ft}$ deep

1 array has never been used; the other is being loaded with hazardous waste

- $\quad 320$ columns in field array -10 in. diameter $\times 6-7 \mathrm{ft}$ deep

ORNL $\quad$ - $\quad 40^{\mathrm{a}}$ waste cylinders containing U-8 $\mathrm{ft}$ d:ameter $\times 10 \mathrm{ft}$ deep

- $\quad 2^{\mathrm{a}}$ Hill Slope Experiments $-3 \mathrm{ft}$ diameter $\times 4 \mathrm{ft}$ deep

- 5 NRC experiment vessels $-3 \mathrm{ft}$ diameter $\times 10 \mathrm{ft}$ deep, 1 LWF

SRS

- 40 defense waste/access caissons $-6 \mathrm{ft}$ diameter $\times 10 \mathrm{ft}$ deep and

$10 \mathrm{ft}$ diameter $\times 20 \mathrm{ft}$ deep

55-gal WF

- 10 special waste/access caissons $-6 \mathrm{ft}$ diameter $\times 10 \mathrm{ft}$ deep

55-gal WF

- $\quad 2$ unused- $6 \mathrm{ft}$ diameter $\times 10 \mathrm{ft}$ deep

- $\quad 31$ saltstone vegetation evaluations $-6 \mathrm{ft}$ diameter $\times 10 \mathrm{ft}$ deep 55-gal WF

- $\quad 3$ saltstone monoliths in hypolon basin $-45 \mathrm{ft}$ long $\times 35 \mathrm{ft}$ wide $\times 14.5 \mathrm{ft}$ deep

- 1 slag saltstone $-6 \mathrm{ft}$ diameter $\times 10 \mathrm{ft}$ deep

55-gal WF

PNL $\quad 10$ defense waste/access caisson $-6 \mathrm{ft}$ diameter $\times 10 \mathrm{ft}$ deep

55-gal WF

WHC

INEL $\quad 3$ weighing types unused $-5 \mathrm{ft}$ wide $\times 5 \mathrm{ft}$ long $\times 6 \mathrm{ft}$ deep

RFP/NTS $\quad-$

a. In planning stage. 


\section{STUDIES OF LYSIMETERS CONTAINING RADIOACTIVE WASTE FORMS}

\section{Savannah River Site}

The Savannah River Site (SRS), located near Aiken, South Carolina, has operated a number of lysimeter facilities. These include lysimeters for the following:a

- Defense waste

- Special waste forms

- Saltstone (large-scale)

- Slag saltstone

- Saltstone environmental uptake

- $\quad$ Tenth-scale saltcrete

- Plutonium chemical forms (minilysimeters)

- $\quad$ Iodine-129

- Tritium

- Polymer-impregnated tritium concrete.

The locations of these facilities are shown in Figure 1. Those still in active use include the defense waste, saltstone (large-scale), and slag saltstone lysimeters.

The defense waste lysimeter is one of the original lysimeter arrays for determining the movement of radionuclides from nuclear wastes. This project was supported by DOE (Hooker and Root 1981). The purpose of the lysimeters was to define leaching and migration rates of radionuclides from typical SRS buried wastes. It was intended that each lysimeter $(1.8 \mathrm{~m}$ or $3.0 \mathrm{~m}$ in diameter and $3.0 \mathrm{~m}$ deep) function as miniature

a. B. Hergesell, 1992, notes from the Field Data Requirements Workshop, DOE Performance Assessment Task Team, August 6, 1992, Santa Fe, NM. burial grounds in which the amount and location of the wastes were controlled and provisions were made for collecting and sampling percolating rainwater. Efforts were made to collect data that could be used to calculate the rates at which radionuclides were being removed from the buried waste forms and its subsequent movement through the soil column. Wastes used in the studies were typical of those generated by SRS and laboratory operations. They included irradiated reactor fuel housings, ion-exchange resins, waste plastics and tools from the plutonium finishing line, and laboratory glassware. These wastes were known to contain $\mathrm{Pu}-238$ and $-239, \mathrm{Co}-60$, Cs-137, Sr-90, C-14, Mn-54, Ru-106, Sb-125, and other miscellaneous fission and activation products. Collectively, these lysimeters became known as defense waste lysimeters (Oblath and Grant 1985). Over a period of 2 years (1978-1980) 40 of these lysimeters were installed (Hooker and Root 1981). There were five lysimeters for each of eight wastes plus two controls rontaining no wastes (Figure 2). The two controls were used to determine if airborne contamination from a nearby burial ground or regional atmospheric fallout could influence lysimeter sample results.

Lysimeters used for the defense waste studies (Hooker and Root 1981) consisted of a single compartment and were constructed of corrugated aluminum (12-gage) culvert sections that were coated with asphalt. The bottom of each lysimeter was sloped and partly filled with gravel to facilitate the drainage of percolating water to a low point that acts as a sump where leachate water would collect and be recovered by pumping (Figure 3). The volume of the sump water was measured during pumping by a totalizer. No other leachate collection was planned and no detectors were installed. Because of leakage, a 20-mil thick polyvinylchloride liner was added and tested to ensure a maximum leak rate of $0.15 \mathrm{~L} / \mathrm{hr}$. The lysimeters (five each) were arranged around a central caisson, which served as an underground storage facility (Figure 4). Soil used in the 

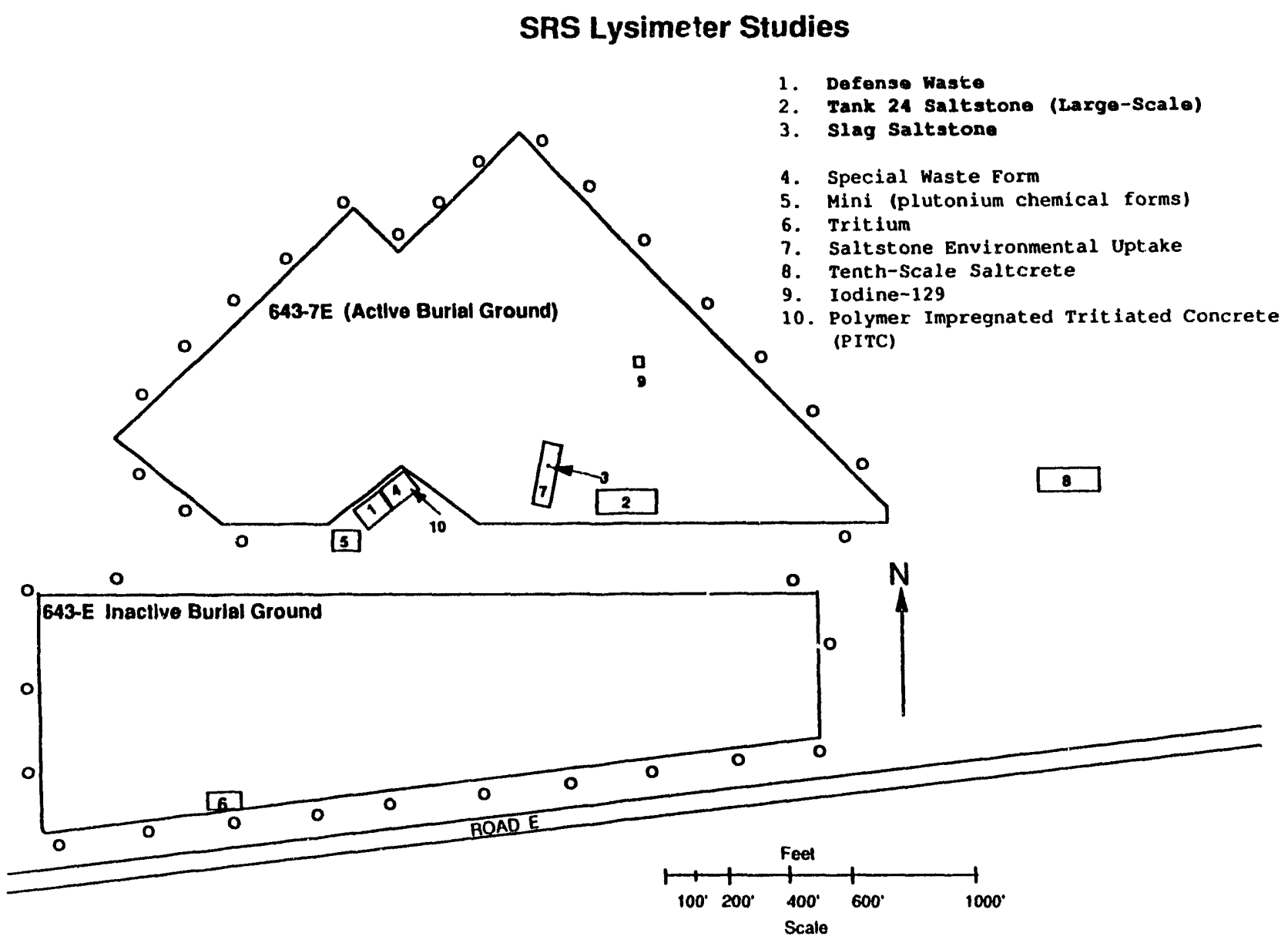

Figure 1. Location of Savannah River Site lysimeter facilities. ${ }^{a}$

a. B. Hergesell, 1992, notes from the Field Data Requirements Workshop, DOE Performance Assessment Task Team, August 6, 1992, Santa Fe, NM. 
Studies o ' Lysimeters Containing Radioactive Waste Forms

CONTROL LYSIMETERS

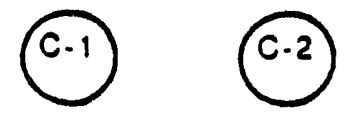

SEPARATIONS GLOVE BOX WASTE<smiles>C1CCCCCC1</smiles><smiles>C1=CCCCCCC1</smiles><smiles>c1ccccc1</smiles><smiles>C1CCCCCC1</smiles>

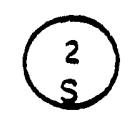

(P)

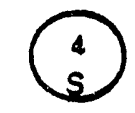

REACTOR MODERATOR RESIN

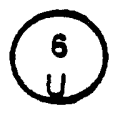

(10

(1)

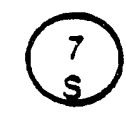

(P)

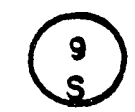

CANYON PIPE JUMPERS

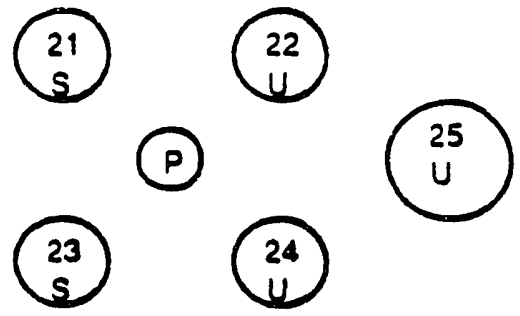

SEPARATIONS LABORATORY WASTE

(26

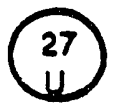

(P)

(28)

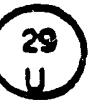

30

u
FINISHING LINE JOB CONTROL WASTE<smiles>C1=CCCCCC1</smiles><smiles></smiles><smiles>c1ccccc1</smiles><smiles>C1=CCCCCC1</smiles>

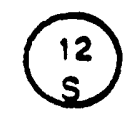

P)

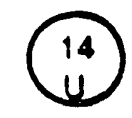

CANYON JOE CONTROL WASTE
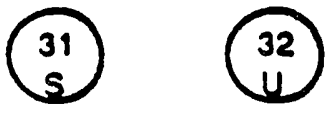

(P)<smiles>C1=CCCCCC1</smiles>

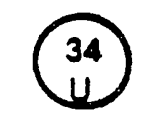

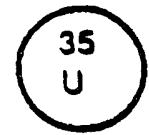

SRL HIGH LEVEL CAVES
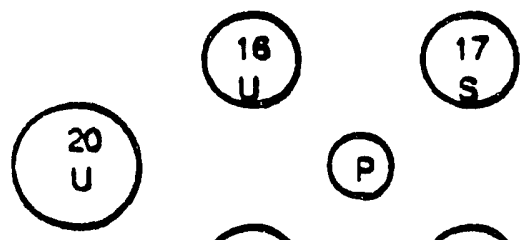

(P)

(18)

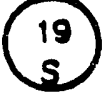

REACTOR SCRAP METAL
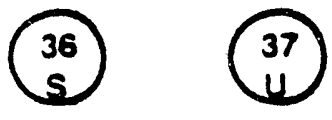

(P)

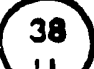

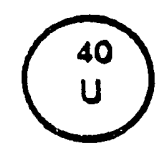

Figure 2. Location and waste type in the Defense Waste Lysimeter Facility. ${ }^{\text {a }}$

a. B. Hergesell, 1992, notes from the Field Data Requirements Workshop, DOE Performance Assessment Task Team, August 6, 1992, Santa Fe, NM. 


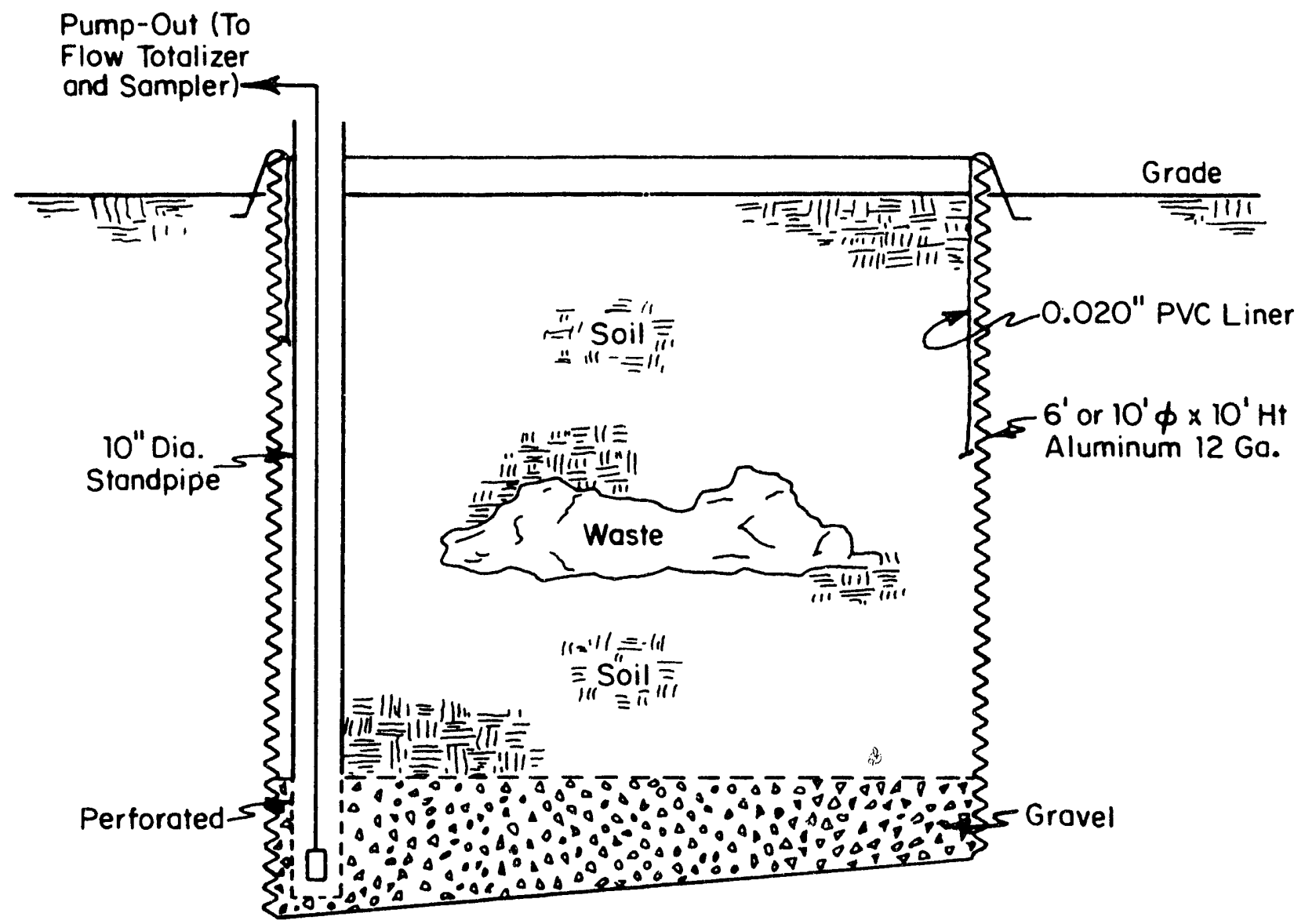

Figure 3. Cross section of SRS defense waste lysimeter (Hooker and Root 1981). 

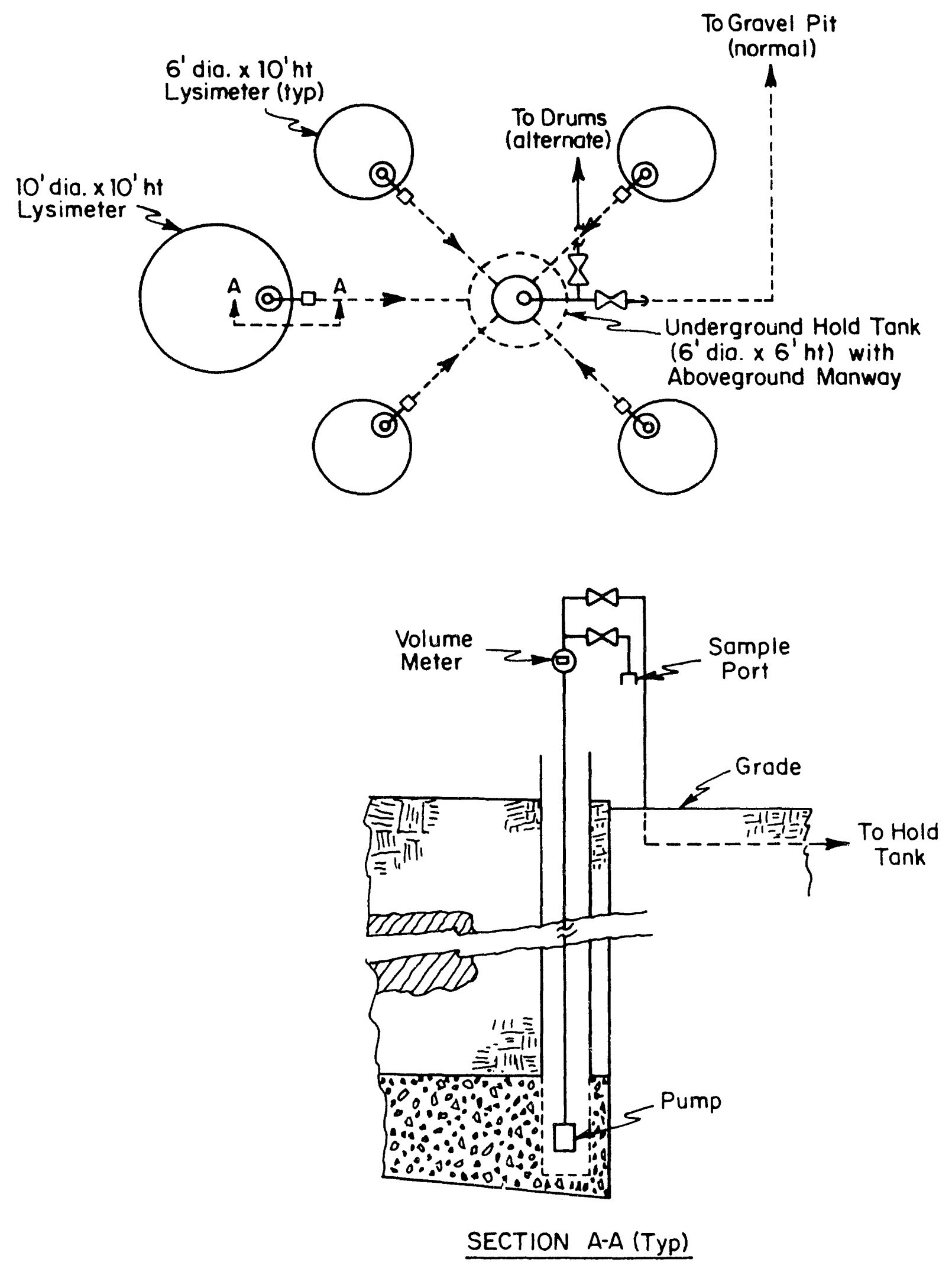

Figure 4. Lysimeter layout at SRS: typical set of five (Hooker and Root 1981). 
lysimeters was selected as being typical SRS burial ground soil. It was accumulated and then mixed with large earth-moving equipment so that variations would be minimized.

The completed lysimeters were used for different studies (Hooker and Root 1981). Two of the 1.8-m-diameter lysimeters of each set were operated in an "unsaturated" mode by maintaining the water level well below the area of the waste. The other two 1.8-m lysimeters were operated under "saturated" conditions with the level water being maintained above the buried waste. The single 3.0-m-diameter lysimeter of each set was maintained in the unsaturated mode. This lysimeter was purposefully made large enough to support the root system of a pine tree. All of the !ysimeters are planted with Pensacola bahia grass. It was intended that the grass be maintained in the same fashion as the surrounding waste disposal area. Leachate sampling from the lysimeters was planned on a monthly schedule for analysis of gamma-emitting nuclides and quarterly for detectron of alpha nuclides and $\mathrm{Sr}-90$.a

Studies using these lysimeters were designed to provide improved radionuclide migration data for assessing the potential long-term hazards from buried radioactive waste. This was done so that decisions about the future disposition of the SRS burial grounds would be based on factual data rather than on sometimes inaccurate approximations. During the time period between lysimeter installation and 1985, the radionuclides $\mathrm{Pu}-238$, Am-241, Sr-90, Co-60, Cs-137, Ru-106, Mn-54, and $\mathrm{Sb}-125$ had been found in leachate waters retrieved from the lysimeters (Oblath and Grant 1985). Cesium-137 was observed for the first time in 1985 while $\mathrm{Mn}-54$ was no longer detected during that sampling period. The maximum level of activity $(1,420 \mathrm{pCi} / \mathrm{L}$ of $\mathrm{Sr}-90)$ was observed in water coming from a lysimeter containing waste from a high-level storage cave. Speciation studies showed that mobile Co-60 was in an anionic form. By 1987, significant levels of $\mathrm{Sr}-90$ and $\mathrm{Pu}-238$

a. B. Hergesell, 1992, notes from the Field Data Requirements Workshop, DOE Performance Assessment Task Team, August 6, 1992, Santa Fe, NM. were observed in leachate water from several of the lysimeters (McIntyre 1987). Releases of $\mathrm{U}-235, \mathrm{Pu}-239$, and Am-241 continued. it was found that by 1985 , evapotranspiration was the dominate factor controlling water movement in ihose lysimeters with pine trees. Currently, leachates from lysimeters 1 through 10 and 21 through 25 continue to be collected and analyzed for the presence of Np-237 and C-14. The other lysimeters are not in operation.

Modeling of radionuclide movement through the lysimeters was done to help predict when measurable levels of activity might be seen in leachate water and thus provide guidance for longterm operations (at least 10 years). It was thought that parameters identified as important for transport through the lysimeters could link laboratory measurements with actual radionuclide migration in the burial trenches.

Downward movement of radionuclides was modeled with a one-dimensional convectivedispersive solute transport equation. Appropriate boundary conditions were then applied. Code parameters considered by the model are found in Table 3. Nuclides evaluated by the modeling were Pu-239 and 238, Cs-137, Sr-90, Co-60, and Ru-106. Based on the results of the modeling, it was concluded that there was a need to define some of the code parameters that influence migration. This included $\mathrm{K}_{\mathrm{d}}$ (distribution coefficient), which is needed for various radionuclides and various soil types; D (dispersion coefficient), which is found to have a strong influence on migration but not known for soil used, and $\mathrm{V}_{\mathrm{w}}$ (groundwater velocity), which should include the effect of the intermittent nature of rainfall on radionuclide migration. The maximum fractional release rates for the nuclides from various types of wastes can be seen in Table 4.

In 1982, ten additional lysimeters were constructed (McIntyre and Hawkins 1987). The purpose was to study the release of radionuclides from samples of nuclear power station low-level radioactive waste that had been solidified by commercial processes. These lysimeters were designated as special waste form lysimeters. Three types of solidifying agents were used. 
Studies of Lysimeters Containing Radioactive Waste Forms

Table 3. Parameters used for SRS transport code (Hooker and Root 1981).

A $=$ Collected terms that account for source diminution:

$A=\frac{V^{2}}{4 D}+K-\gamma$.

$\mathrm{X}=$ Distance in vertical direction $(\mathrm{L})$.

$\mathrm{C}(\mathrm{X}, \mathrm{t})=$ Concentration of radionuclide at $\mathrm{X}$ and $\mathrm{t}\left(\right.$ activity $\left./ \mathrm{L}^{3}\right)$.

$\mathrm{C}_{\mathrm{o}}=$ Initial concentration of radionuclide (activity $\left./ \mathrm{L}^{3}\right)$.

D $\quad=\quad$ Dispersion coefficient $\left(\mathrm{L}^{2} / \mathrm{t}\right)$.

$\mathrm{V}=\quad$ Velocity of radionuclide in groundwater $(\mathrm{L} / \mathrm{t})$. This is related to the groundwater velocity by

$V=V_{w}\left(\frac{1}{1+K_{\imath} R}\right)$

$\mathrm{V}_{\mathrm{w}} \quad=\quad$ Groundwater velocity $(\mathrm{L} / \mathrm{t})$.

$\mathrm{K}_{\mathrm{d}} \quad=\quad$ Distribution coefficient of soil for radionuclide ( $\left.\mathrm{L}^{3} / \mathrm{mass}\right)$.

R $=$ Retardation factor $=[\rho / \eta]\left(\operatorname{mass} / L^{3}\right)$.

$\rho \quad=\quad$ Soil bulk density $\left(\operatorname{mass} / \mathrm{L}^{3}\right)$. Assumed $=1.5 \mathrm{~g} / \mathrm{cm}^{3}$.

$\eta \quad=\quad$ Effective porosity (dimensionless). Assumed $=0.25$.

$\mathrm{t}=$ Time.

$\mathrm{K}=$ Radioactive decay constant for radionuclide $(1 / \mathrm{t})$.

$\gamma \quad=\quad$ Source depletion constant (may be a combination of leaching, radioactivity decay, etc.) $(1 / t)$. 
Table 4. Maximum fractional nuclide release rates from SRS defense waste form lysimeters (private communication with H. Sturm, 1987).

\begin{tabular}{|c|c|c|}
\hline Waste type & Isotope & $\begin{array}{l}\text { Release rate } \\
\text { (fraction/year) } \\
1985 \\
\end{array}$ \\
\hline Scrap metal & Mn-54 & $10^{-9}$ \\
\hline HLC/AMF & Co-60 & $10^{-5}$ \\
\hline Resin, scrap metal & - & $10^{-7}$ \\
\hline Resin & Sr-90 & $10^{-7}$ \\
\hline Canyon jumpers & - & $10^{-3}$ \\
\hline HLC/AMF, separations, labs, canyon job control & - & $10^{-5}$ \\
\hline HLC/AMF & Ru-106 & $10^{-5}$ \\
\hline Resin & Cs-137 & $10^{-6}$ \\
\hline HLC/AMF & Pu-238,239 & $10^{-8}$ \\
\hline HLC/AMF & Am-241 & $10^{-6}$ \\
\hline
\end{tabular}

These included Portland type II cement (four waste forms), vinyl ester styrene (VES) (four waste forms), and masonry cement (two waste forms). The Portland cement and VES waste forms contained sodium sulfate evaporator bottoms, with several of them also containing spent ion-exchange resin. The masonry waste forms used waste from a pressurized water reactor and consisted of boric acid wastes. The dominant radionuclides present in this waste were Co-60, Cs-137, Mn-54, and Sr-90. Characterization of these waste forms is reported in Neilson et al. (1982). All waste forms were molded in 55-gal drums. Before burial, each drum casing was stripped away so that the waste form was unprotected.

Lysimeters used for the special waste form studies (McIntyre and Hawkins 1987) were constructed of fiberglass Flowtite wet wells measuring $1.8 \mathrm{~m}$ in diameter and $3.0 \mathrm{~m}$ deep. The bottom of each contained $30.5 \mathrm{~cm}$ of gravel to act as a sump for collecting percolating water. Almost $1 \mathrm{~m}$ of indigenous soil was placed on the gravel. The unprotected waste form was placed in the middle of the exposed soil surface; two porouscup soil moisture samplers were installed 5 to
$8 \mathrm{~cm}$ below the waste form; and remaining space in the lysimeter was filled with soil. Each lysimeter was fitted with a $30.5-\mathrm{cm}$-diameter steel pipe extending to the bottom of the wet well that served as an access for sampling the sump. In-place flowmeters accurately measured the volume of collected leachate during sump pumping (Figure 5). Waste form location and detector placement are seen in Figure 6.

In January 1983, analysis began on water that was obtained on a routine basis from the ten lysimeters. Monthly samples of leachated have been analyzed for gamma-emitting nuclides and $\mathrm{Sr}-\mathbf{9 0}$. Results from these analyses indicate that the annual release of radionuclides is less than $0.01 \%$ of the source term value. Cobalt-60 and $\mathrm{Sr}-90$ are the major nuclides detected in the leachate water. By 1987, the rate of Co-60 released from the cement waste forms was approximately two orders of magnitude greater than for the VES (McIntyre and Hawkins 1987). The concentration of $\mathrm{Sr}-90$ in leachate water from lysimeters containing both cement and VES was low. The average concentration of Sr-90 for the VES waste forms was $2.5 \mathrm{pCi} / \mathrm{L}$; for the cement waste forms, this value was $0.5 \mathrm{pCi} / \mathrm{L}$. These results 
Studies of Lysimeters Containing Radioactive Waste Forms

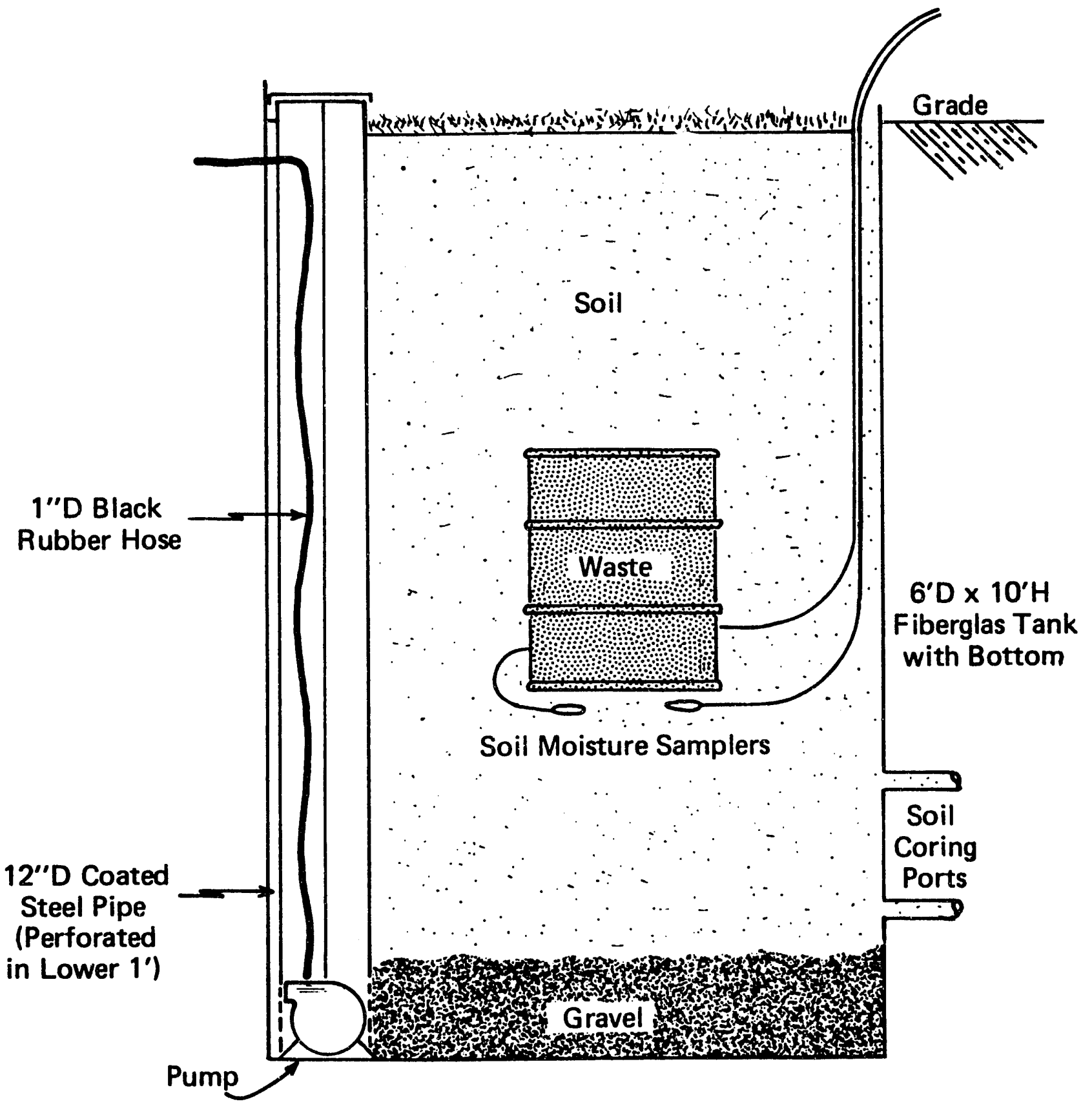

Figure 5. Diagram of SRS special waste form lysimeter $(1.8 \mathrm{~m} \times 3.5 \mathrm{~m})$ fiberglass tank (McIntyre and Hawkins 1987). 

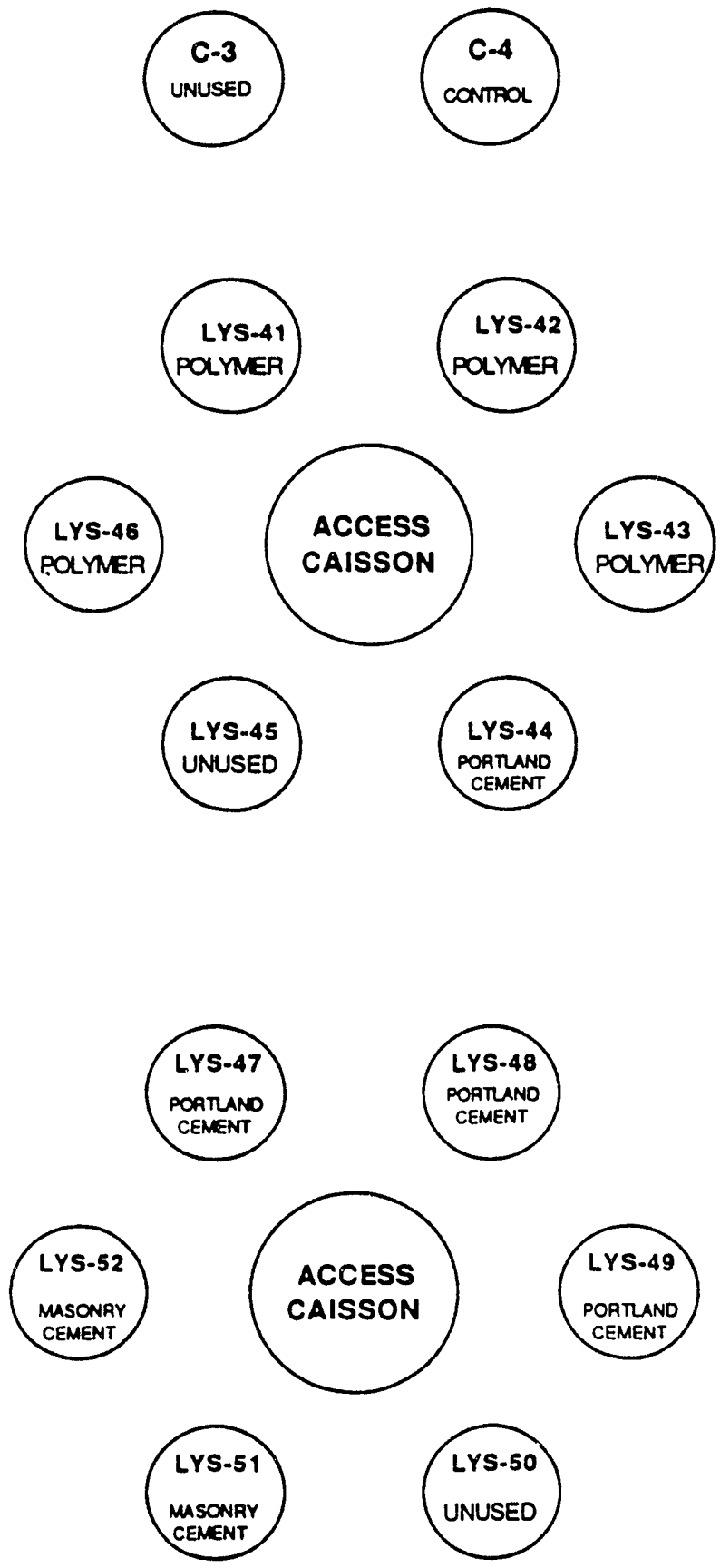

Figure 6. Arrangement of special waste form lysimeters in the SRS burial ground (McIntyre and Hawkins 1987).

lead to the conclusion that the VES waste forms were more effective for Co-60 retention while cement is more effective for $\mathrm{Sr}-90$. Leachate from one of the cement lysimeters showed Cs-137 levels at $250 \mathrm{pCi} / \mathrm{L}$. This nuclide was not expected to be found in the leachate water (because of sorption to soil), and it was suggested that the movement was occurring because of channel development in the soil profile. Figures 7 through 17 display cumulative nuclide releases from the lysimeters during the first 5 years of operation. No data have been reported since 1987 .

High-level nuclear wastes are stored in large underground tanks at SRS. Processing of these wastes produces two waste streams. The lowlevel waste stream is mixed with a blend of cementitious blast furnace slag and fly ash. The resulting waste form, called saltstone, is disposed onsite by emplacement in an engineered aboveground vault.

A large-scale demonstration of the disposal of saltstone was incorporated into a lysimeter facility at SRS (McIntyre et al. 1989). By using the lysimeter, personnel could measure the infiltration of water and the migration rate of soluble components through soil by collecting and analyzing leachate from a drainage sump. The lysimeters consist of an earthen basin lined with Hypalon. The waste form was produced by pouring saltstone grout into a trench formed inside the earthen basin. Each saltstone monolith was constructed using $9,500 \mathrm{~L}$ of actual radioactive waste consisting of decontaminated salt solution $(\sim 70 \mu \mathrm{Ci} / \mathrm{L}$ of radioactivity composed primarily of Tc-99 and H-3 at a pH greater than 12.5). Table 5 provides data on the average composition of chemical compounds and radionuclides of the salt solution used in the formulation of a monolith. Figure 18 shows the placement of the waste and the lysimeter and monolith dimensions.

Three separate lysimeters were constructed to evaluate the performance of saltstone disposal in earthen trenches. The first (uncapped lysimeter) contains only a buried monolith with the second containing a monolith covered with a clay cap (clay cap lysimeter). The third lysimeter (gravel cap lysimeter) had a cap of pea-sized gravel. Rainwater that percolates through the soil was collected in individual prefabricated cement sumps installed at the bottom of each lysimeter. 
Studies of Lysimeters Containing Radioactive Waste Forms

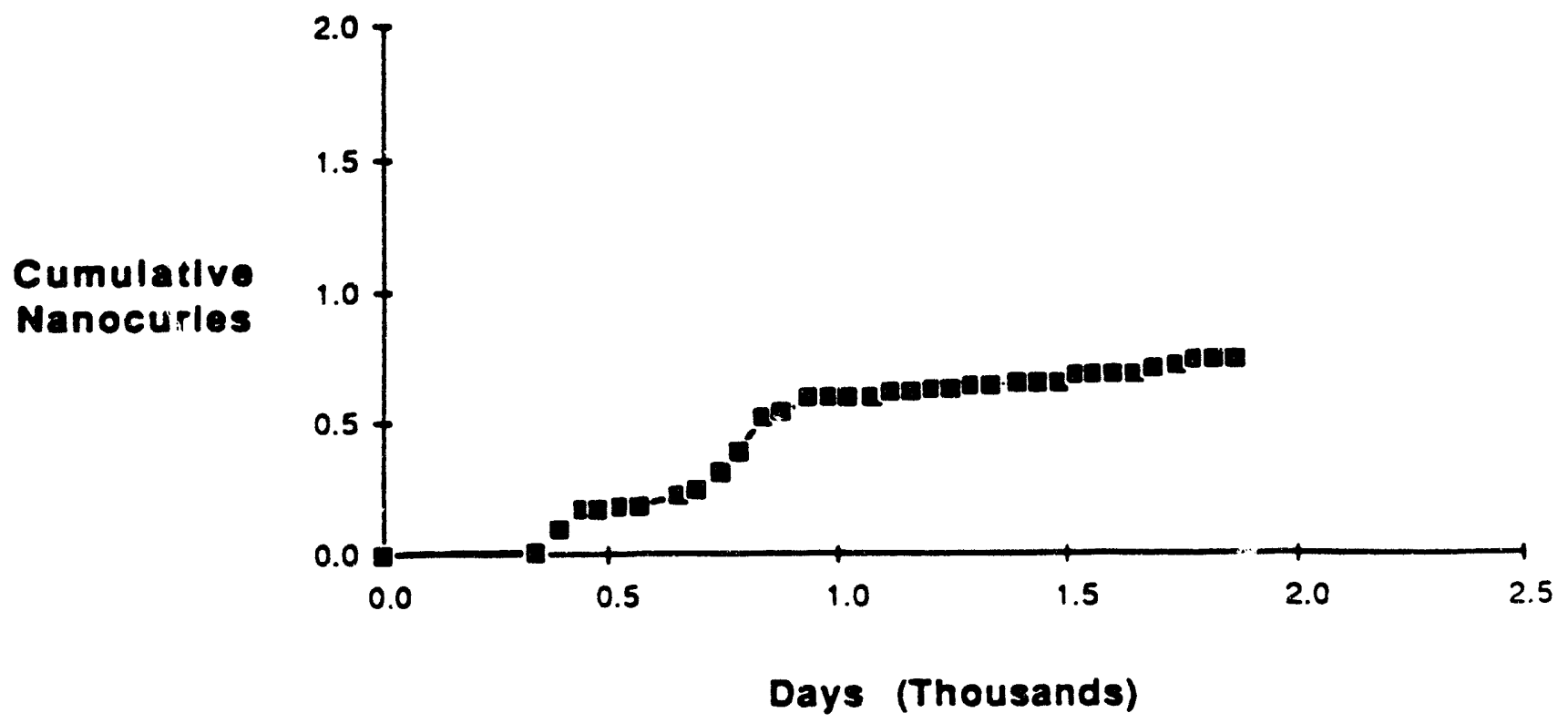

Figure 7. Cumulative (o-60) of lysimeter 41 from SRS special waste form lysimeter (Mclntyre and Hawkins 1987).

\section{Cumidatlve Nanocurles}

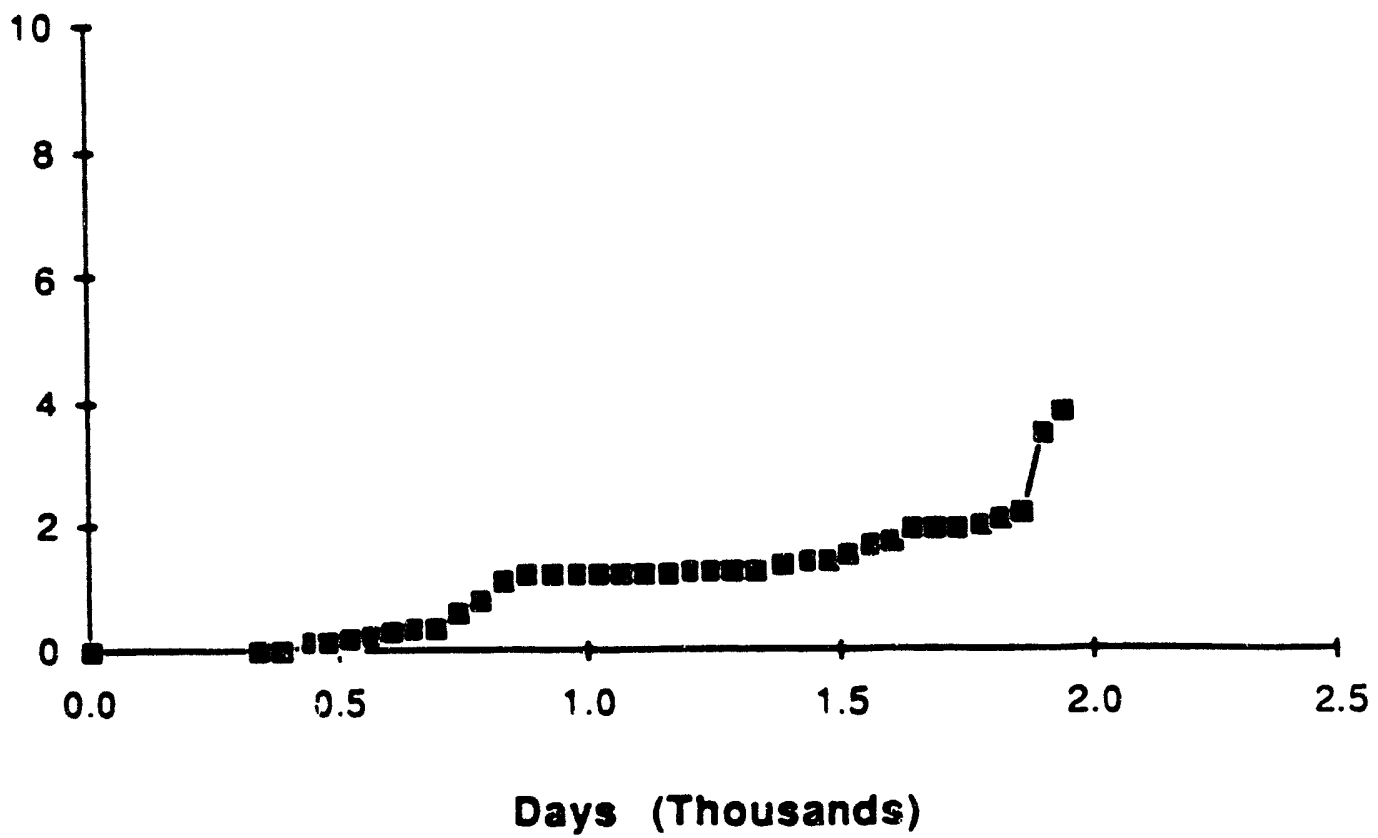

Figure 8. Cumulative Co-60) of lysimeter 42 from SRS spec 1 waste form lysimeter (McIntyre and Hawkins 1987). 


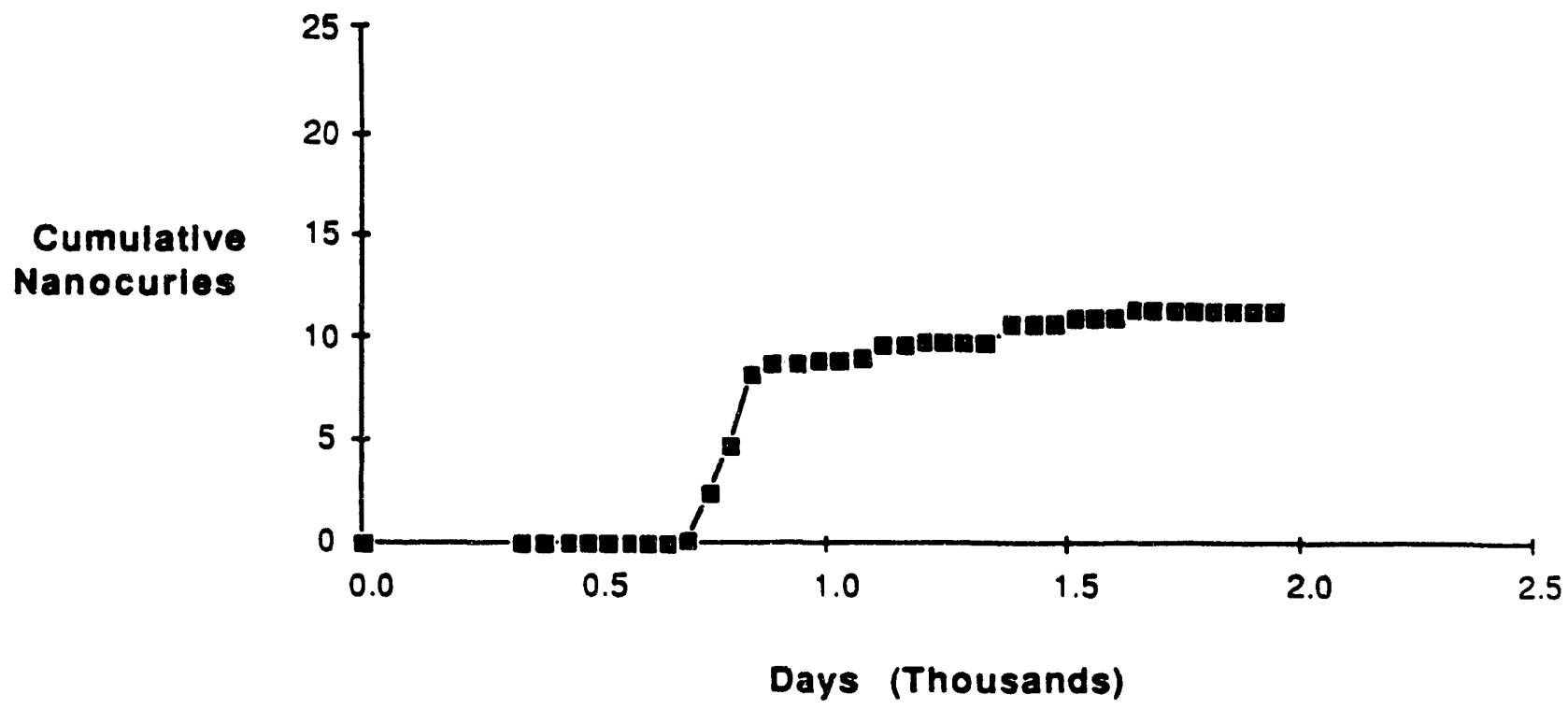

Figure 9. Cumulative Co-60 of lysimeter 43 from SRS special waste form lysimeter (McIntyre and Hawkins 1987).

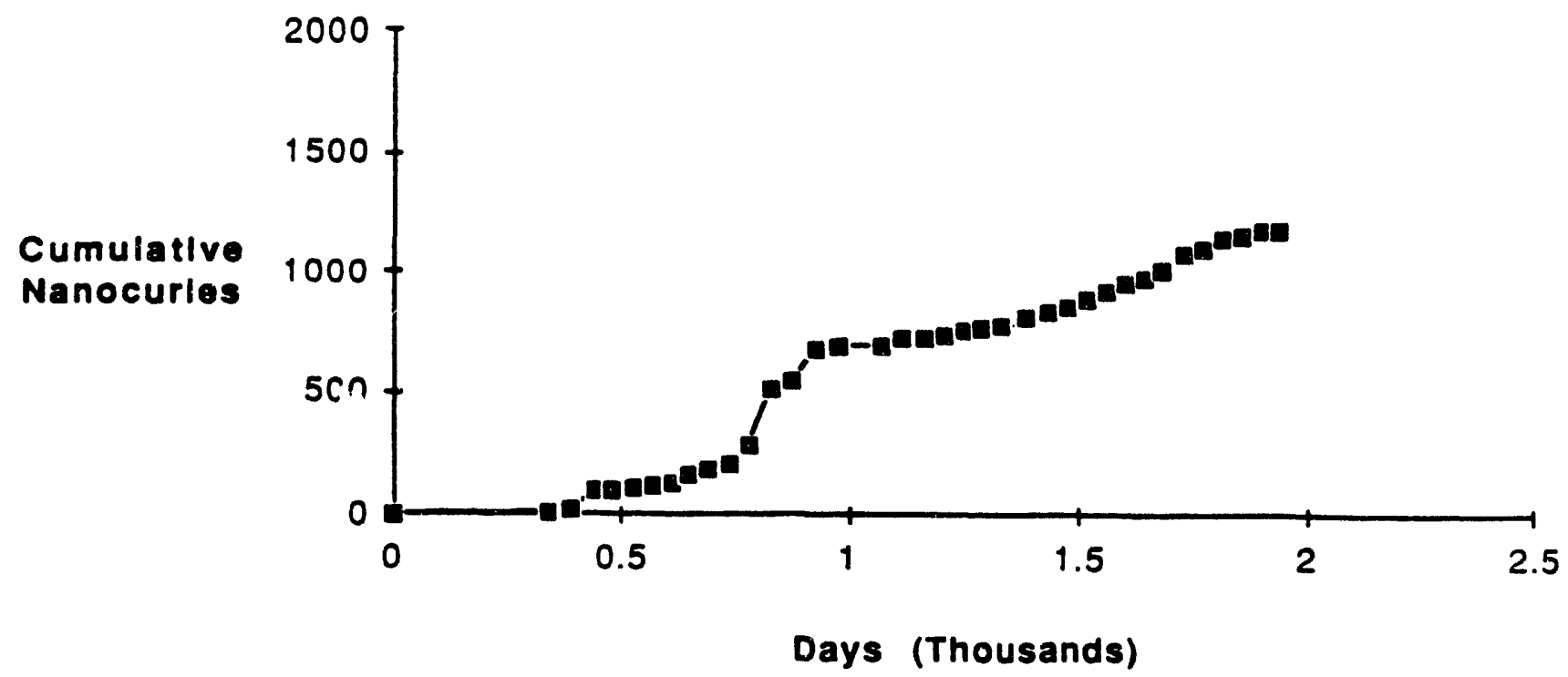

Figure 10. Cumulative Co-60 of lysimeter 44 from SRS special waste form lysimeter (McIntyre and Hawkins 1987). 
Studies of Lysimeters Containing Radioactive Waste Forms

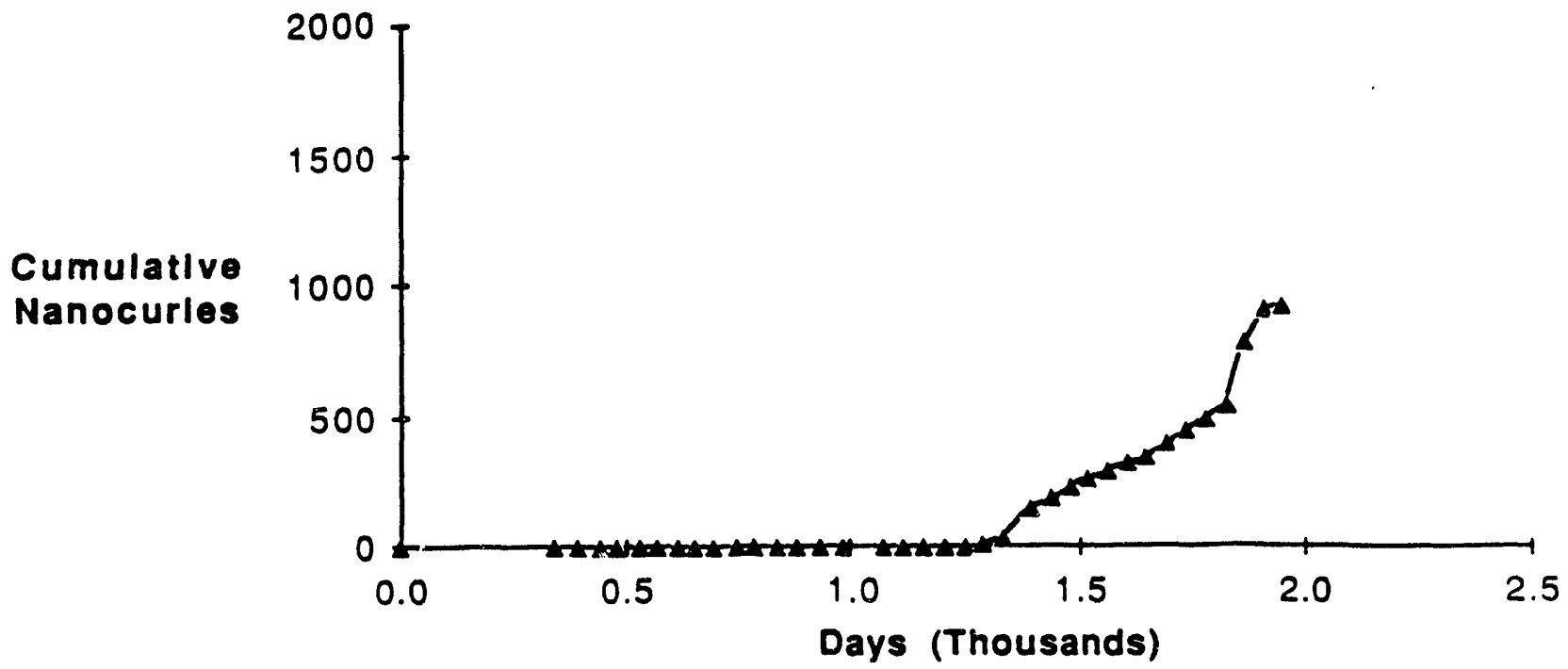

Figure 11. Cumulative Cs-137 of lysimeter 44 from SRS special waste form lysimeter (McIntyre and Hawkins 1987).

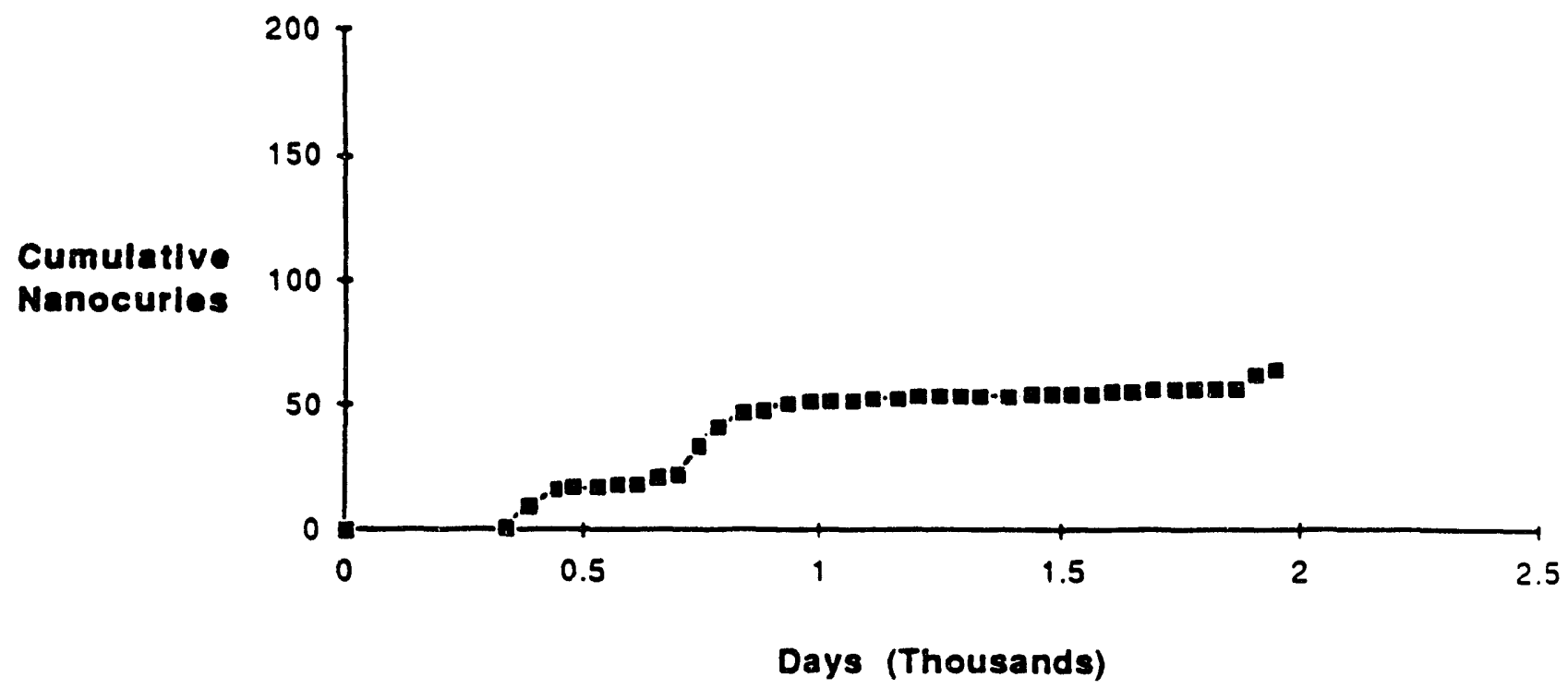

Figure 12. Cumulative Co-60 of lysimeter 46 from SRS special waste form lysimeter (McIntyre and Hawkins 1987). 


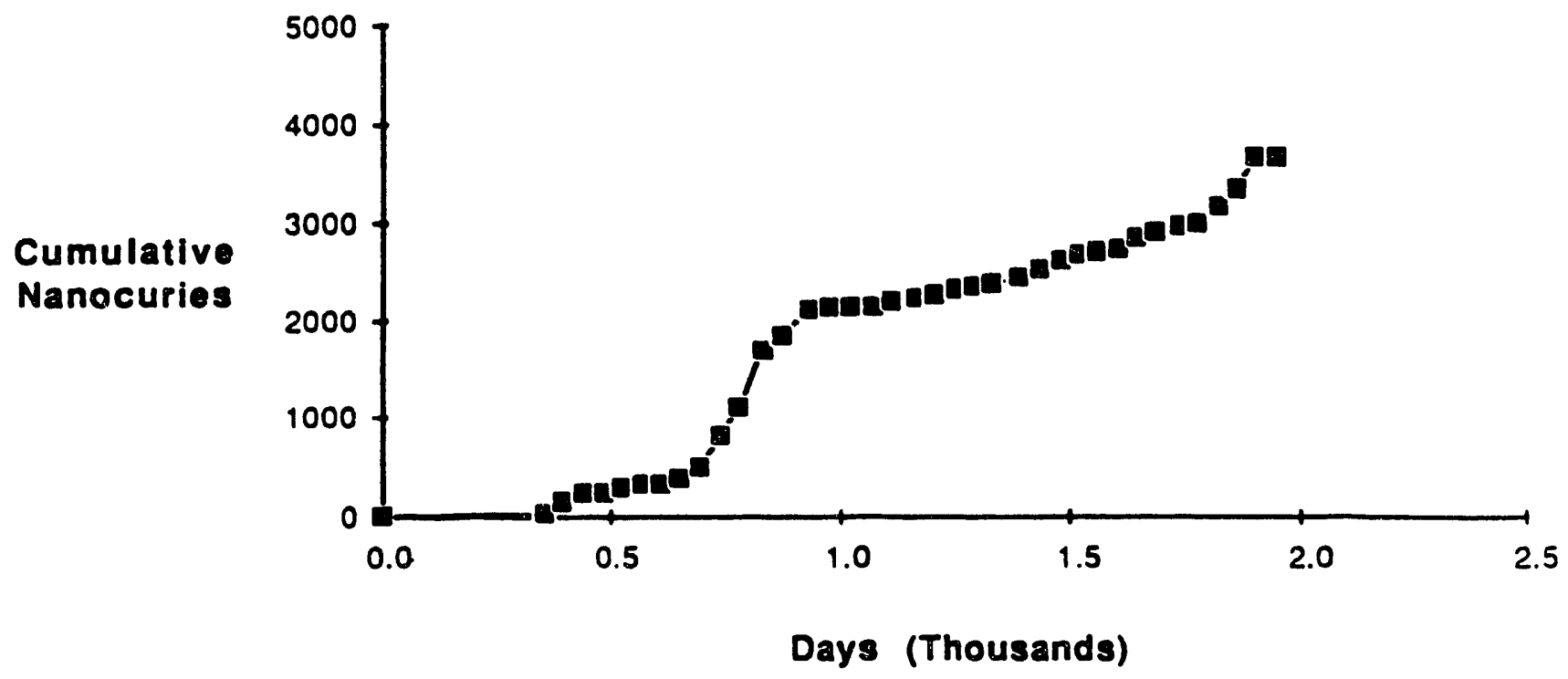

Figure 13. Cumulative Co-60 of lysimeter 47 from SRS special waste form lysimeter (McIntyre and Hawkins 1987).

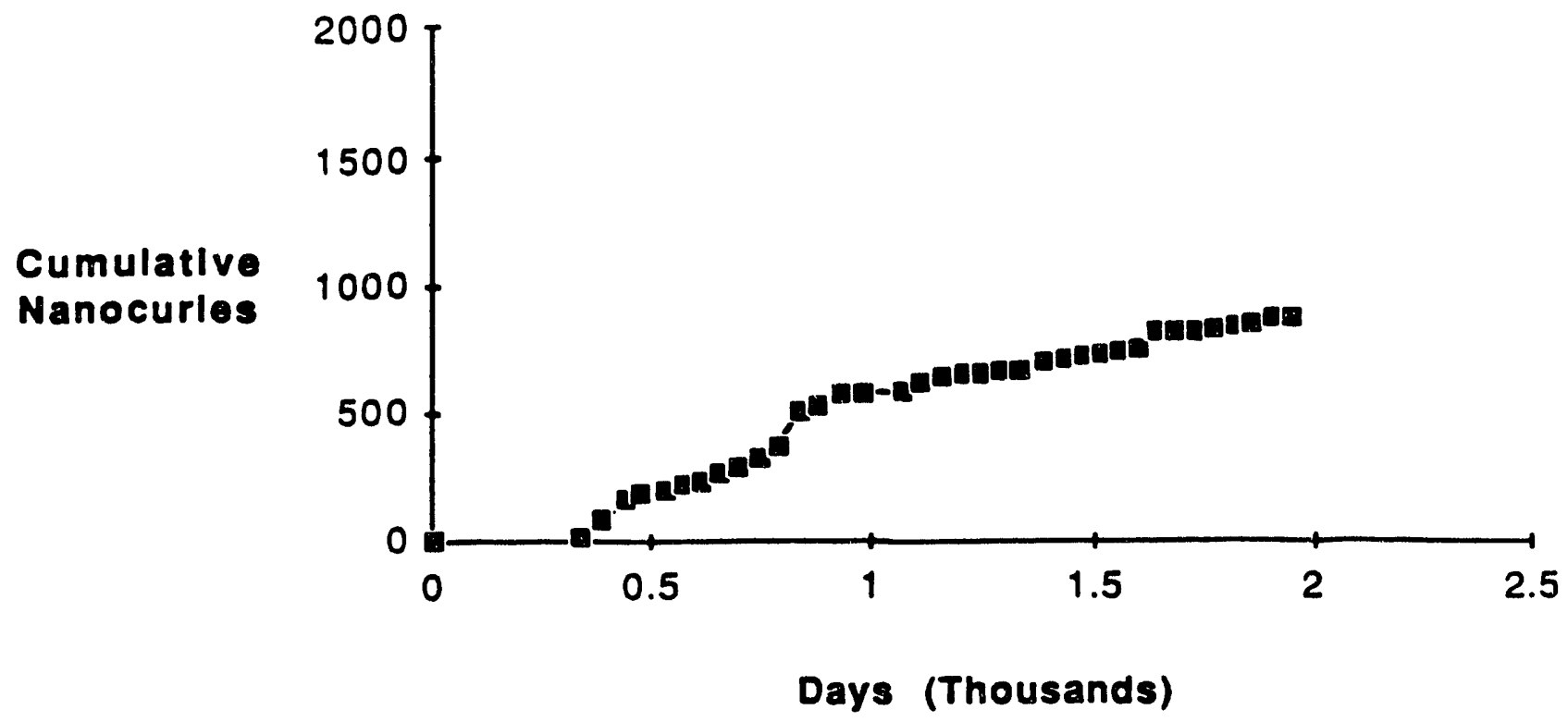

Figure 14. Cumulative Co-60 of lysimeter 48 from SRS special waste form lysimeter (McIntyre and Hawkins 1987). 
Studies of Lysimeters Containing Radioactive Waste Forms

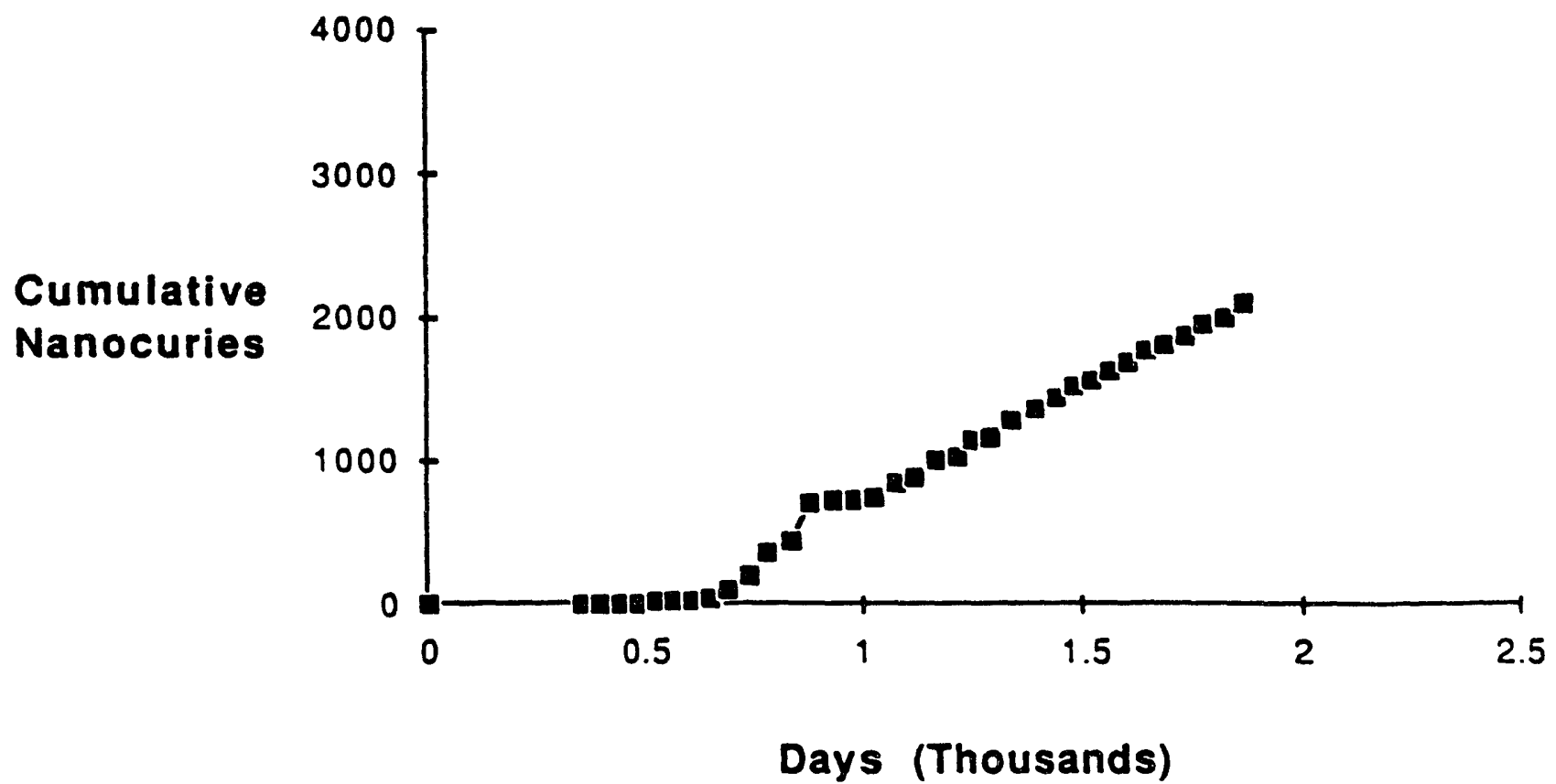

Figure 15. Cumulative Co-60 of lysimeter 49 from SRS special waste form lysimeter (McIntyre and Hawkins 1987).

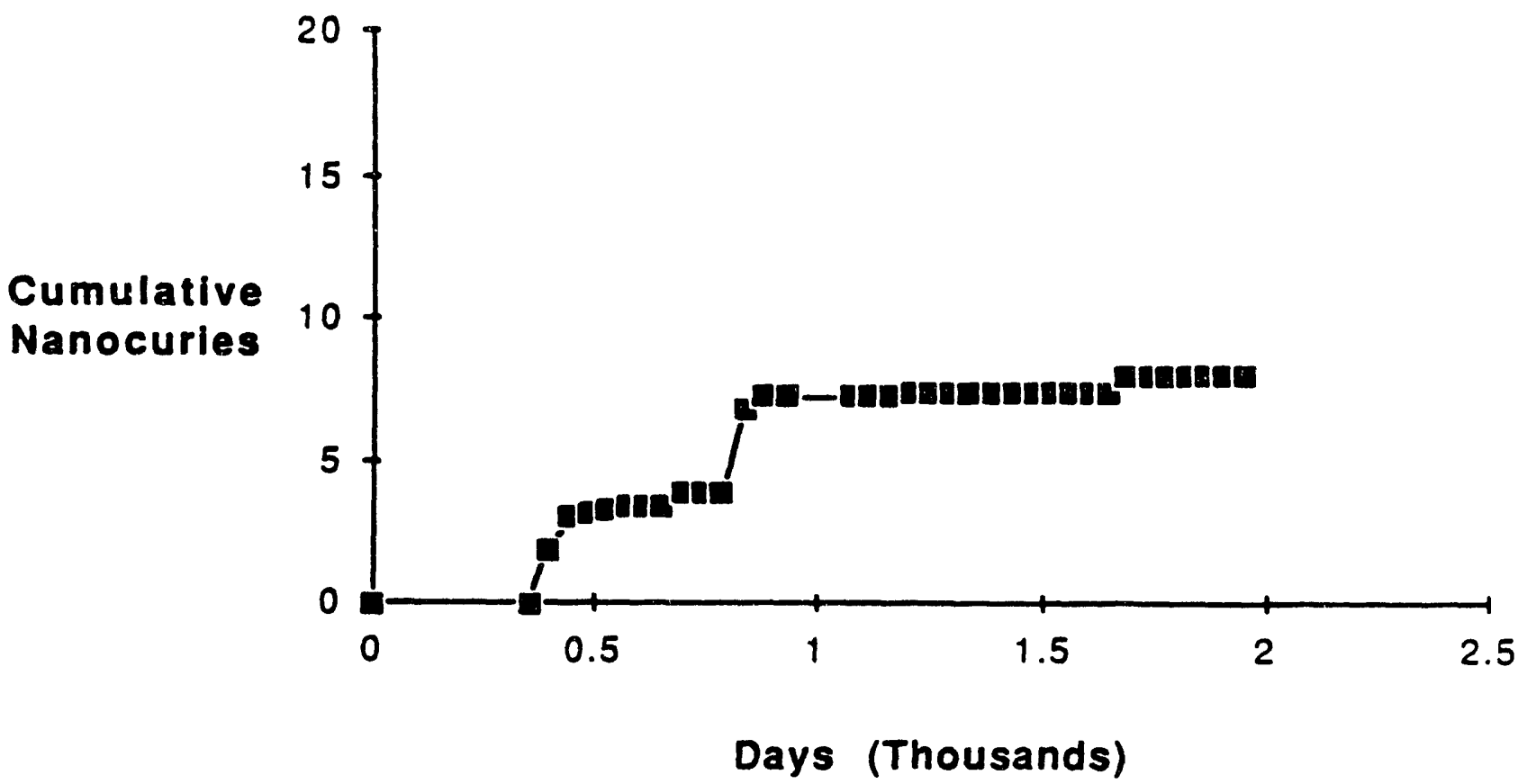

Figure 16. Cumulative Co-60 of lysimeter 51 from SRS special waste form lysimeter (McIntyre and Hawkins 1987). 


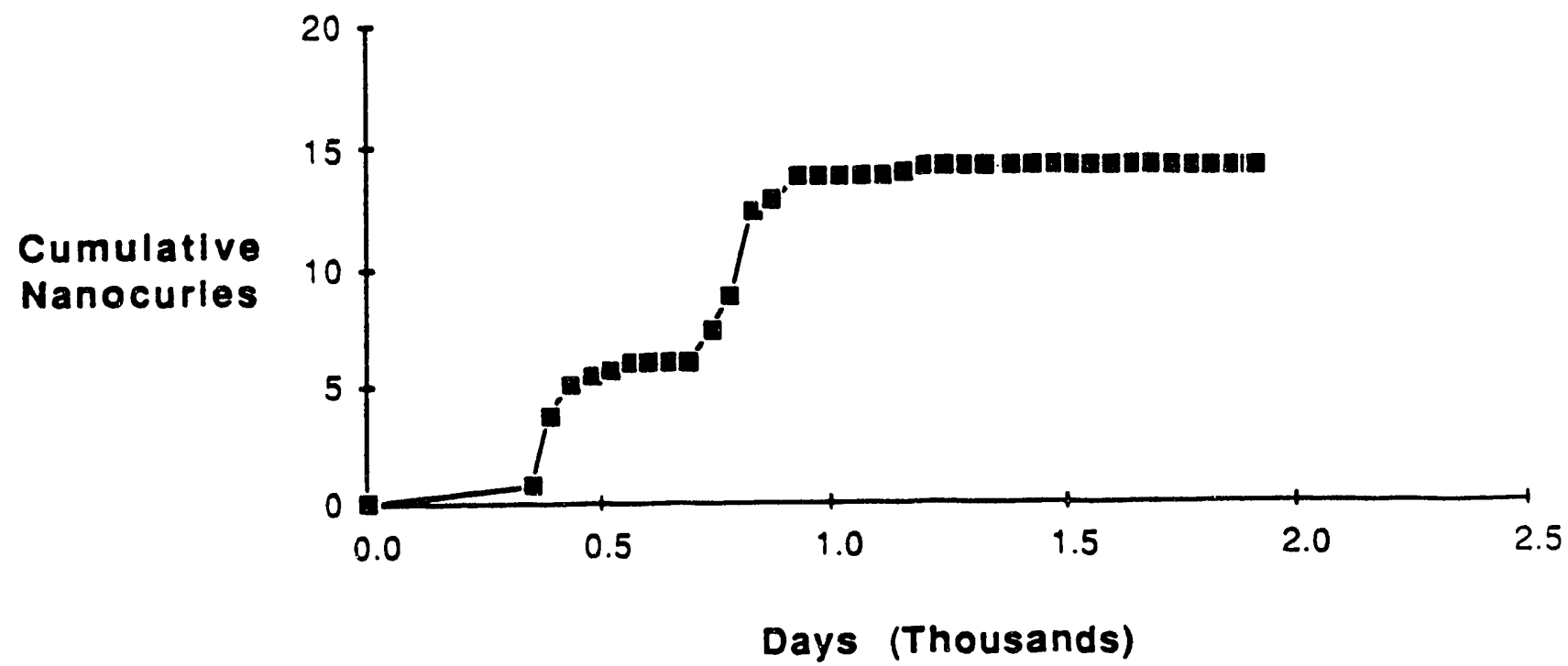

Figure 17. Cumulative Co-60 of lysimeter 52 from SRS special waste form lysimeter (McIntyre and Hawkins 1987).

Table 5. Chemical and radionuclide composition of decontaminated salt solution (McIntyre et al. 1989).

\begin{tabular}{|c|c|c|c|}
\hline Chemical & Weight $\%$ & $\underline{\text { Radionuclide }}$ & $\mathrm{nCi} / \mathrm{g}$ of solution \\
\hline $\mathrm{H}_{2} \mathrm{O}$ & 70 & Tc-99 & 35 \\
\hline $\mathrm{NaNO}_{3}$ & 17.7 & $\mathrm{H}-3$ & 12 \\
\hline $\mathrm{Na}_{2} \mathrm{CO}_{3}$ & 2.1 & Rh-106 & 6.6 \\
\hline $\mathrm{NaAl}(\mathrm{OH})_{4}$ & 2.6 & Ru-106 & 6.6 \\
\hline $\mathrm{NaOH}$ & 3.6 & Sb- 125 & 3.5 \\
\hline $\mathrm{Na}_{2} \mathrm{SO}_{4}$ & 1.7 & Cs- 137 & 1.7 \\
\hline $\mathrm{NaNO}_{2}$ & 0.9 & Ba-137m & 1.7 \\
\hline $\mathrm{CaSO}_{4}$ & 0.24 & Sr-90 & $<0.3$ \\
\hline $\mathrm{NaCl}$ & 0.005 & Y-90 & $<0.3$ \\
\hline $\mathrm{NaB}\left(\mathrm{C}_{6} \mathrm{H}_{5}\right)_{4}$ & 0.04 & Pu-239 & $<0.4$ \\
\hline $\mathrm{NaF}$ & 0.004 & & \\
\hline $\mathrm{NaSiO}_{3}$ & 0.006 & & \\
\hline $\mathrm{Na}_{2} \mathrm{CrO}_{4}$ & 0.006 & & \\
\hline $\mathrm{Na}_{2} \mathrm{MoO}_{4}$ & 0.0004 & & \\
\hline $\mathrm{NaHgO}(\mathrm{OH})$ & $2 \times 10^{-6}$ & & \\
\hline $\mathrm{NaAg}(\mathrm{OH})_{2}$ & $<1 \times 10^{-7}$ & & \\
\hline
\end{tabular}



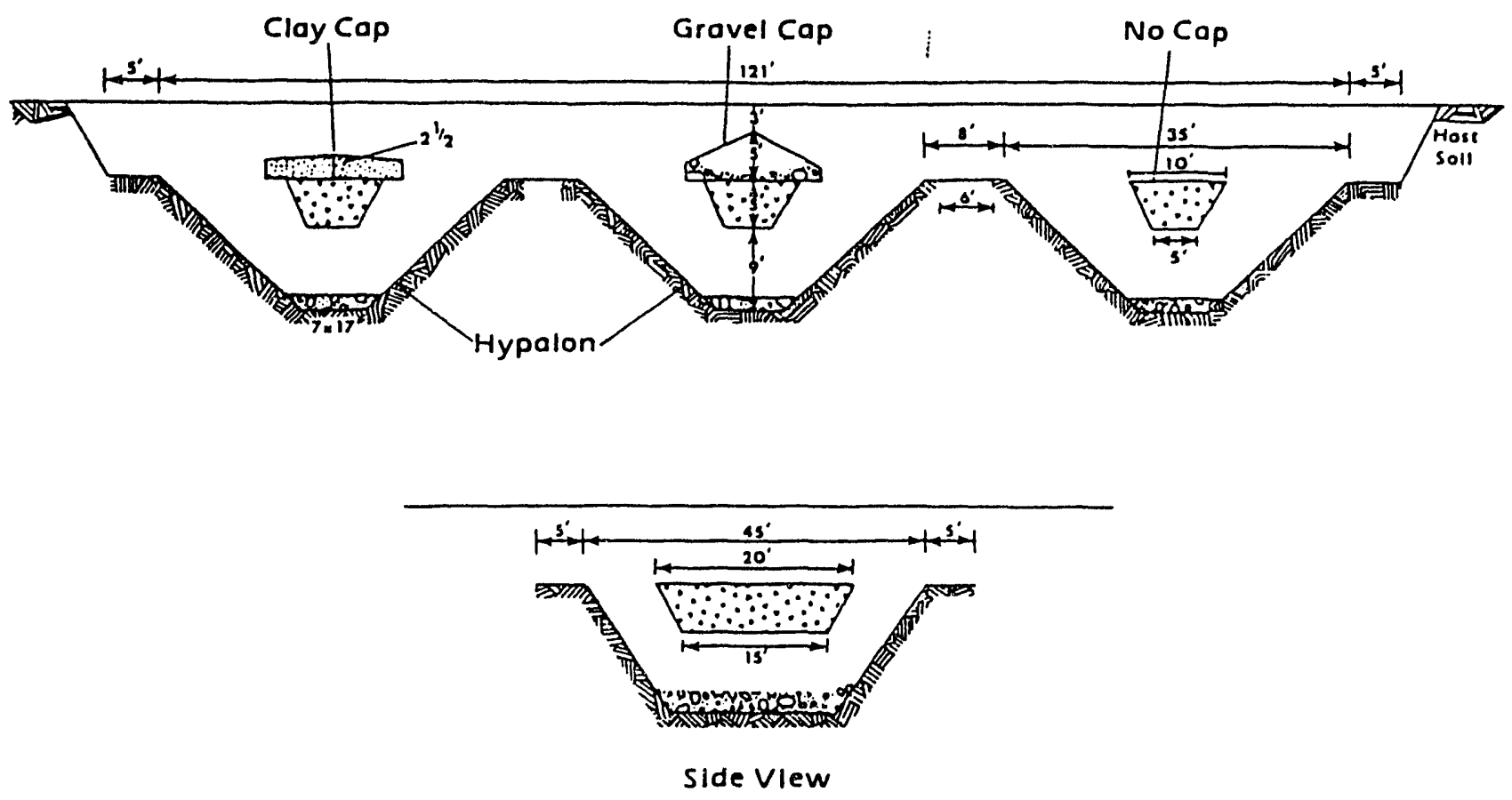

Figure 18. Diagram of SRS saltstone lysimeters (McIntyre et al. 1989).

Samples from each sump were collected biweekly. Soil moisture could be collected using moisture samplers installed in the lysimeter basin within $15 \mathrm{~cm}$ of each monolith. A rain gage was present at the lysimeter site. Precipitation event data were recorded biweekly. Samples of precipitation were submitted for chemical analysis to provide background levels for nitrate, mercury, calcium, sodium, sulfate, gross alpha, technetium, and tritium that were detected in leachate. This lysimeter project is presently active.

The primary purpose of the project was to determine if leachate from the monoliths maintain levels of dissolved components in the groundwater such that they did not exceed drinking water standards. Data indicate that leaching was dependant on the cover over the monolith. The uncapped lysimeter was the only one to show significant nitrate levels above background. Nitrate is a primary component of saltstone. The maximum nitrate concentration reported was $209 \mathrm{ppm}$. After some delay, the gravel-capped lysimeter has produced leachate with abovebackground levels of both nitrate and Tc-99. Leachate from the clay capped lysimeter contained no compound above background levels.
Technetium-99 was the most abundant radionuclide detected in the sump leachate of the uncapped lysimeter. This was of interest since the most abundant nuclide in the waste was tritium. The maximum level of Tc-99 observed was $11.9 \mathrm{nCi} / \mathrm{L}$, whereas levels in both capped lysimeters remained at background, or in the case of the gravel-capped lysimeter, slightly above background. Leachate from the uncapped lysimeter contained 50 to $55 \mathrm{nCi} / \mathrm{L}$ Tc-99. Alpha activity was not detected in the leachate sample. Water samples from the soil moisture samplers near the monoliths had significantly higher concentrations of ionized salt species than those in the leachate.

Both numerical and analytical mathematical models were developed to predict the release of nitrate and other materials from various saltstone disposal designs. One model was developed by SRS and another (FAMOS) by Intera Technologies. FAMOS is a full, two-phase model that simulates the movement of both air and water phases in unsaturated soil. Model inputs included measured rainfall, estimates of runoff, and evaporation, as well as measured unsaturated flow properties and diffusivities of soil, saltstone, and clay-cap materials. A favorable comparison was 
achieved between FAMOS and experimental results. Predicted release levels using the SRS model were somewhat lower, but also showed a correlation with experimental results. The experimental results identified nitrate and Tc-99 as the major components released from the monoliths.

The slag saltstone study uses one lysimeter and was installed in 1985. ${ }^{a}$ The lysimeter is constructed of fiberglass and is $6 \mathrm{ft}$ in diameter and $10 \mathrm{ft}$ deep. The waste form is a cylindrical slag formulation weighing $240 \mathrm{~kg}$ with an activity of approximately $5.25 \mathrm{mCi}$. This active project includes biweekly leachate sampling. Data on actual Ti-99 releases from the lysimeter have been found to have a good correlation with release rates and subsequent plant uptake rates as predicted by modeling.

The saltstone environmental lysimeter ${ }^{\text {al }}$ facility is also used to study saltstone wastes. It consists of 32 lysimeters $6 \mathrm{ft}$ in diameter and either $6 \mathrm{ft}$ or 10 feet long, with vegetative covers of either loblolly pine, Bermuda grass, or a rotation of corn, wheat, and soybean. It was installed in 1984 and was operated through 1990. Wastes used in the study were from the original saltstone formulation and consisted of nine blocks with dimensions of $11 \times 14 \times 3$ in. The combined activity from the blocks in each lysimeter was $3 \mathrm{mCi}$. Plant, soil, and leachate water samples were obtained.

The tenth-scale lysimetera was installed in 1982 and, like the large-scale saltstone lysimeters, is an earthen basin of trapezoidal design that is lined with hypalon and typar. It has a leachate collection system and is covered with a clay cap. It contains eight blocks with a combined mass of $38,800 \mathrm{~kg}$ of saltcrete grout. Nitrate makes up $1,600 \mathrm{~kg}$ of the waste-form mass. No actual radioactive waste was used in the waste form's formulation; therefore, no measurable activity exists. The facility is now closed, but during the active phase, monthly water samples were

a. B. Hergesell, 1992, notes from the Field Data Requirements Workshop, DOE Performance Assessment Task Team, August 6, 1992, Santa Fe, NM. obtained from the two leachate collection sumps and soil water samplers for nitrate analysis.

Movement of plutonium was studied with 12 mini-lysimeters. ${ }^{\text {a }}$ These 13 -gal inverted polyethylene carboys were installed in 1980 and are now inactive. They contained actinide waste forms emplaced on filter discs. Seven of these lysimeters contain waste forms of different compounds of plutonium; four contain a variety of sludge and glass wastes; and one is used as a control without waste. Each lysimeter contains approximately $475 \mu \mathrm{Ci}$ of activity.

One lysimeter constructed in 1976 (now inactive) was used for a study of I-129 movement. ${ }^{a}$ It consisted of an earthen basin $10 \times 10 \times 12 \mathrm{ft}$ with a 20-mil PVP liner. Waste forms used in the I-129 lysimeter were spent saddles containing I-129 with an activity of $68.7 \mathrm{mCi}$. Weekly leachate samples were obtained over the 4-year life of the study.

The tritium lysimeter facility a was constructed in 1973 (now inactive) and consisted of two cylindrical steel caissons $10 \mathrm{ft}$ in diameter and $10 \mathrm{ft}$ deep. One of the lysimeters contained waste forms composed of spent LI-Al melts in two stainless steel crucibles, while the other one contained no waste and served as a control. Activity of the waste was estimated to be between 300 and $450 \mathrm{Ci}$. Leachate and air samples were collected from the lysimeters during the study. Data on H-3 movement obtained from this study were found to have a good correlation with movement predicted by the PATHRAE model (Rogers and Hang 1987).

\section{Hanford Site}

A companion study to the special waste form (moist environment) study that is being conducted at SRS is the special waste form study being conducted by Pacific Northwest Laboratory (PNL) for DOE at the Hanford Site in Richland, Washington. This facility was selected for the study as the arid component of the special waste form testing program. The program was initiated in 1983 for the purpose of studying the release of radionuclides from samples of nuclear 
power station low-level radioactive waste solidified using commercial formulations (Jones et al. 1988; Colombo et al. 1986). The intent was to study releases under burial conditions at an arid site. In this study, four different solidification agents were used. They included masonry cement (two waste forms), bitumen (two waste forms), Portland type III cement (four waste forms), and VES (two waste forms) (Jones et al. 1988). The masonry cement and bitumen waste forms contain boric acid evaporator concentrates; two of the Portland cement waste forms contain sodium sulfate evaporator concentrates; the other two contain the sodium sulfate concentrate plus ion-exchange resin; and the VES forms contain sodium sulfate concentrate plus resin. Those waste forms were also characterized by BNL (Neilson et al. 1982). The dominant nuclides contained in the wastes were Co-60 and Cs-137. Additional radioactive elements include Cs-134, $\mathrm{Mn}-54$, and H-3. As in the case of SRS, these waste forms were molded in 55-gal drums with the drum casing being removed before being placed into the lysimeter.

The lysimeter complex consists of 10 soilfilled caissons $(1.83 \mathrm{~m} \times 3.05 \mathrm{~m})$, placed concentrically around a central access caisson (Figure 19). Each lysimeter contains one waste form sample. Each lysimeter is equipped with a gravity drain leading to the central access caisson

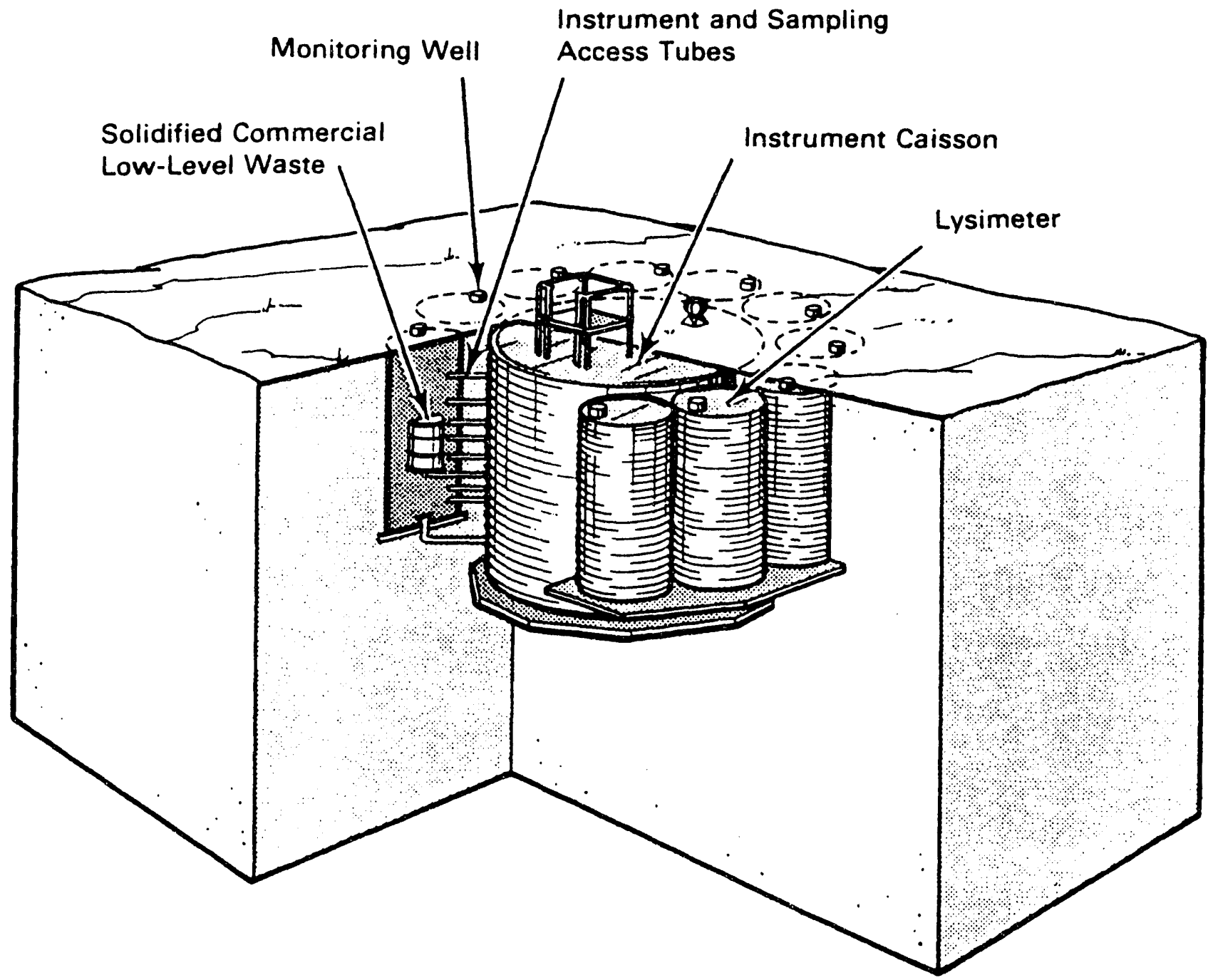

Figure 19. Diagram of PNL special waste form lysimeter facility (Jones et al. 1988). 
for collection of leachate water. The central caisson also provides access to each lysimeter through horizontal sampling ports. A $15-\mathrm{cm}$ diameter well is installed at the side of each lysimeter to allow down-well gamma-ray scanning and neutron probe measurements of soil water content. Lysimeters are instrumented with 12 thermocouples to measure the vertical soil temperature profile, four fiberglass resistance blocks to monitor soil water potential, and five porous-cup soil moisture samplers to allow extraction of soil solution samples.

Waste forms were buried in the lysimeters during 1984. Drainage measurements of leachate were made once a month during 1985 and then once every 2 to 3 weeks thereafter. All drainage samples were analyzed for radionuclides, with complete cation/anion analysis being performed quarterly. Soil moisture in the lysimeters was measured twice monthly with the neutron probe, and continuously with the soil moisture blocks (as was soil temperature).

Cobalt-60) and $\mathrm{H}-3$ are the only two radionuclides that have been found in lysimeter leachates

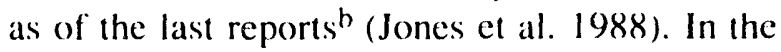
1988 report, $\mathrm{CO}-60$ had been found in leachate from the lysimeters with the four type III cement wastes forms and in one with the VES. By 1990, the nuclide was found in leachate from all the lysimeters, and was the primary constituent in leachate from the four lysimeters containing cement waste and from two lysimeters with VES. All of these waste forms contained either sodium sulfate concentrate or sodium sulfate concentrate plus exchange resin. The total amount of $\mathrm{Co}-60$ mobilized in the lysimeters since the initiation of the study (Figure 20 ) has been less than $0.10 \%$ of the available inventory. While these releases were not compared to releases from other studies, they were considered to be low. It was pointed out, however, that these releases are significant because laboratory sorption studies had indicated

b. R. J. Serne and T. L. Jones, Letter Report: "FY-90 Water Balance, Drainage, and Radionuclide Release, with Comments," September 28, 1990, Pacific Northwest Laboratory, Richland, WA 99352. that Co-60 should be highly absorbed into soil clays similar to those at Hanford. Therefore, no measurable quantities were expected to reach the lysimeter drains. The presence of $\mathrm{Co}-60$ suggests that leaching of a small but highly mobile fraction of Co-60 has occurred. It was hypothesized that the formation of organic complexes between $\mathrm{Co}-60$ and organic chelating agents found in the waste was responsible. The above data suggest that the cement was releasing more Co-60 than was the VES. Also, it appeared that the cumulative release was more dependent on time than on the quantity of water moving through the soil profile. This suggests that the conditions for $\mathrm{Co}-60$ release may be consistent with some sort of diffusion-controlled source. As of 1990, the maximum release rate of $\mathrm{Co}-60$ from the lysimeters was about $3 \mu \mathrm{Ci} / \mathrm{cm}$ of drainage water.

A qualitative comparison of laboratory and field data for $\mathrm{Co-60}$ reveals several similarities. ${ }^{\mathrm{h}}$ The amount of $\mathrm{Co}-60$ found in laboratory results compares well with the relative amounts of $\mathrm{Co}-60$ found in the leachates from different waste forms made from different solidification agents. The order of release was cement, VES, and then bitumen. As a further comparison, the amount of Co-60) found in the lysimeter leachate is consistent with the small amount of mobile Co-60) leached from laboratory soil columns in past studies.

Tritium was found in the leachate from both lysimeters containing the boric acid/masonry cement waste forms. The total quantity of $\mathrm{H}-3$ recovered in each of these lysimeters (Figure 21) represented 73 to $78 \%$ of the inventory of this nuclide in the two buried waste forms. It appears that a fairly constant rate of about $107 \pm 29$ and $115 \pm 13 \mu \mathrm{Ci} / \mathrm{cm}$, respectively, of drainage water had been established for the two leachate streams. Laboratory leaching studies support the field data with regard to rapid release of tritium from the cement waste forms. Cesium and Mn-54 have not yet been found in the leachate solutions.

Nonradioactive constituents of the waste were also found to be migrating through the soil. High 


\section{Studies of Lysimeters Containing Radioactive Waste Forms}

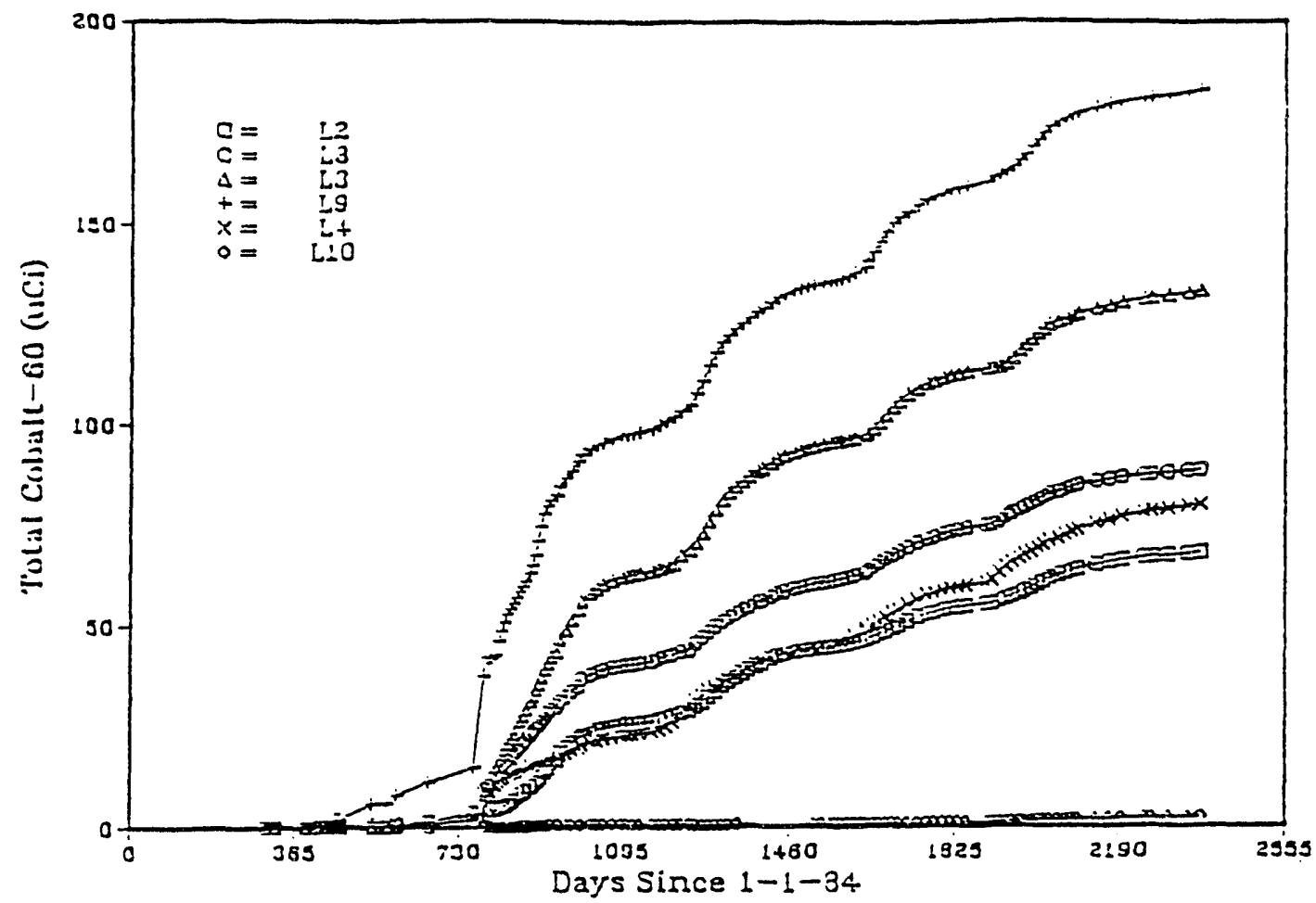

Figure 20. Cumulative Co- 60 from PNL special waste form lysimeters $2,3,4,8,9$, and $10 .^{\mathrm{b}}$

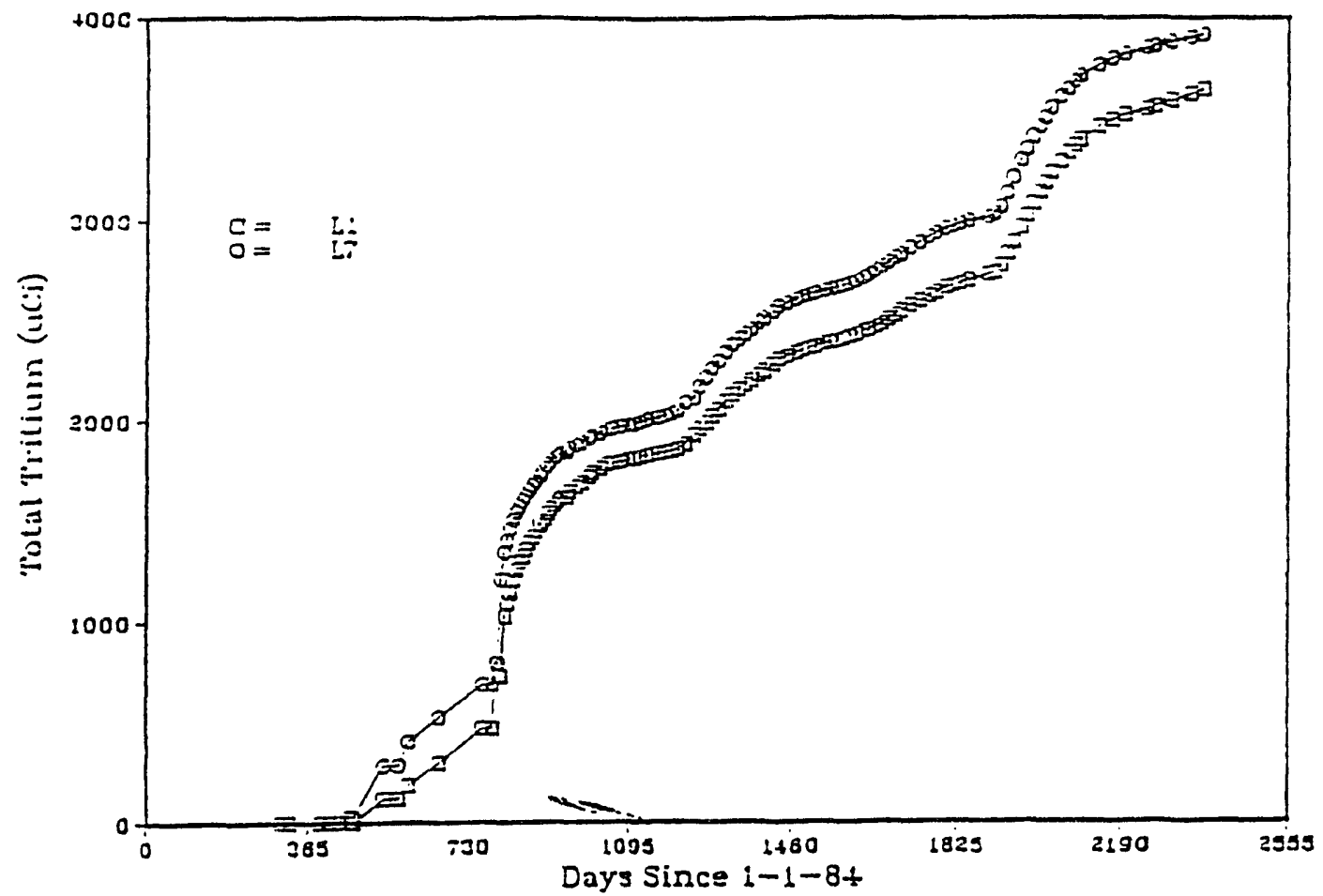

Figure 21. Cumulative $\mathrm{H}-3$ from PNL special waste form lysimeters 1 and $7 .^{b}$

b. R. J. Serne and T. L. Jones, Letter Report: "FY-90 Water Balance, Drainage, and Radionuclide Release, with Comments," September 28, 1990, Pacific Northwest Laboratory, Richland, WA 99352. 
amounts of sodium, sulfate, boron, calcium, and magnesium are found in various wastes (Table 6). All of these major components were found in the respective leachate samples. It appears that much of the sodium being released from the sodium sulfate wastes has displaced calcium from the soil by replacing it on the soil exchange sites. It was assumed in Jones et al. (1988) that this resulted in excess calcium appearing in the leachates with lower sodium levels than anticipated. It also appeared that the release of boron from the boric acid waste forms was being retarded to a significant degree due to waste form chemistry.

The program collected extensive hydrologic and chemical data over the reporting period relating to the leaching of waste forms under field conditions. Analysis of these data has been largely qualitative and speculative. The next phase of the program, not yet funded, was to begin an iterative process of model simulation and model calibration to provide quantitative interpretation of the existing data. Preliminary analysis of the data indicated that they provided a more definitive analysis of source terms associated with low-level waste than was possible with laboratory data alone.

It was intended that this lysimeter array provide data to aid in the performance assessment of the waste forms. While there are diverse pathways in nuclide transport, contaminants must first leave the waste form. Therefore, if movement is to be modeled, the initial modeling step, regardless of the pathway, is 10 characterize the release of contaminants from the waste form. There are three characteristics of a waste form that determine its role as a source of contamination: (a) the inventory of contaminants contained in the waste form, (b) the chemical speciation of the contaminants being released from the waste, and (c) the tendency of the contaminants to leave the waste form (Jones et al. 1988). This latter characteristic differs from the other two in that it may depend as heavily on the burial environment (i.e., soil type and climate) as on properties of the waste form. Together, inventory, species, and release rate (or concentration) constitute the source term. Lysi- meter data are being used in this experiment to define the source term for these wastes.

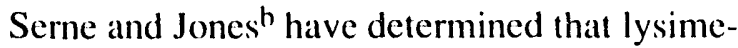
ter data can be useful in making a preliminary evaluation for the selection of appropriate release models used in performance assessment modeling. They point out that the data show that all the contaminants found in the Hanford waste forms are not instantaneous releases. Therefore, the use of an instantaneous release hypothesis would not be justified and, if used, would be an unrealistic commitment to conservatism. Constant amount or fraction release models also appear to be in conflict with available lysimeter data. It appears that a release model based on cumulative drainage would better fit the Hanford data, though this type of model has not been used frequently in performance assessment modeling. Another conclusion was that the validity of standard diffusion-controlled leach models cannot be tested without rigorous modeling of the lysimeter leaching process. Finally, it was pointed out that whether or not laboratory-measured "effective" diffusion coefficients can be used to predict leach rates cannot be answered until the Hanford lysimeter data are analyzed as part of a rigorous model validation exercise. It appeared at the time that perhaps a modeling approach, based upon the amount of water draining through a burial site, might be necessary. Such models are also not known to be widely used in performance assessment modeling.

In addition to testing waste forms in the ficld with lysimeters, the work by PNL at Hanford included laboratory studies designed to evaluate the ability of such studies to predict leaching under field conditions (Criscenti and Serne 1987). Laboratory investigations with waste forms included batch leaching, soil adsorption column. and soil/waste form column experiments. These were conducted using the Portland type III cement waste forms containing the evaporator

b. R. J. Serne and T. L. Jones, Letter Report: "FY-90) Water Balance, Drainage, and Radionuclide Release, with Comments," September 28, 1990, Pacific Northwest Laboratory, Richland, WA 99352. 
Studies of Lysimeters Containing Radioactive Waste Forms

Table 6. Total amount of nonradioactive elements leached from PNL special waste form lysimeters (Jones et al. 1988).

\begin{tabular}{lrrrrrrrrr}
\hline Drum & $\begin{array}{rrrr}\mathrm{Ca} \\
(\mathrm{g})\end{array}$ & $\begin{array}{c}\mathrm{Na} \\
(\mathrm{g})\end{array}$ & $\begin{array}{c}\mathrm{K} \\
(\mathrm{g})\end{array}$ & $\begin{array}{c}\mathrm{Mg} \\
(\mathrm{g})\end{array}$ & $\begin{array}{c}\mathrm{Sr} \\
(\mathrm{g})\end{array}$ & $\begin{array}{c}\mathrm{NO}_{3} \\
(\mathrm{~g})\end{array}$ & $\begin{array}{c}\mathrm{SO}_{4} \\
(\mathrm{~g})\end{array}$ & $\begin{array}{r}\mathrm{Cl} \\
(\mathrm{g})\end{array}$ & $\begin{array}{c}\mathrm{B} \\
(\mathrm{g})\end{array}$ \\
\hline 4- IB & 41.4 & 12.3 & 4.9 & 9.8 & 0.17 & 99.2 & 23.0 & 2.1 & 0.06 \\
1-1B & 152.0 & 198.6 & 8.3 & 42.2 & 0.65 & 48.2 & 764.6 & 14.0 & 0.02 \\
2-1B & 163.6 & 309.5 & 8.2 & 50.5 & 0.70 & 23.2 & $1,114.3$ & 18.3 & 0.02 \\
7-2B & 163.8 & 170.4 & 8.2 & 41.5 & 0.71 & 34.8 & 675.2 & 20.6 & 0.05 \\
Drum 1 & 21.7 & 9.1 & 4.0 & 5.0 & 0.10 & 34.1 & 17.5 & 1.4 & 4.28 \\
Drum 2 & 39.0 & 12.7 & 4.7 & 9.4 & 0.18 & 54.2 & 21.9 & 2.5 & 8.89 \\
4-2B & 40.1 & 14.1 & 5.1 & 8.2 & 0.21 & 76.6 & 29.4 & 2.3 & 0.10 \\
1-2B & 147.3 & 290.9 & 24.3 & 54.3 & 0.79 & 33.7 & $1,021.1$ & 21.2 & 0.05 \\
2-2B & 152.5 & 392.0 & 28.1 & 53.9 & 0.82 & 46.4 & $1,143.8$ & 23.1 & 0.04 \\
7-3B & 46.3 & 20.3 & 3.0 & 10.9 & 0.21 & 7.5 & 78.9 & 3.5 & 0.04 \\
\hline
\end{tabular}

concentrates and ion-exchange resin waste. The studies included (a) batch leaching experiments, in which either cement or cement mixed with the radioactive waste stream was placed in contact with groundwater, (b) soil adsorption column experiments, in which either groundwater or leachate from the batch experiments contacted soil, and (c) soil/waste form column experiments, in which either a blank or a real waste form was buried in soil and exposed to groundwater as it passed through the columns. Results from these studies were used as input data for the ion speciation/solubility and mass transfer computer code MINTEQ and also to explore factors controlling the major element chemistry of experimentally produced leachates. The objectives of the study were to examine the ion speciation/solubility results from MINTEQ to determine potential solubility controls for both the major and minor elements present in the leachates from the laboratory experiments, and to examine how these elements are speciated in leachate solutions. The ions evaluated included $\mathrm{Ca}, \mathrm{Mg}, \mathrm{Si}, \mathrm{B}, \mathrm{CO}_{3}, \mathrm{SO}_{4}$, and $\mathrm{PO}_{4}$. Data on the release of radionuclides were not provided.

Results from the study indicated that interaction with either cement or a cement with waste alters the groundwater composition. The effects of the waste on the leachate composition were significant during the initial contact period but decreased with continued waste form/ groundwater interaction. The initial effects included an increase in $\mathrm{pH}$, increased alkalinity, and increases in concentrations of $\mathrm{Na}, \mathrm{K}, \mathrm{SO}_{4}$, $\mathrm{PO}_{4}$, and organic carbon. These effects were observed in both the batch leaching and soil/ waste form column experiments but not observed with the soil adsorption column experiments. It was speculated that minerals that would be likely to precipitate to form a reaction rim around the cement waste forms include calcite, dolomite, sepiolite, and quartz. Precipitation of these minerals would explain why low concentrations of $\mathrm{Ca}$, $\mathrm{Mg}$, and Si were observed in leachate solutions. It was the intent of the investigators to apply these finding to the field lysimeter leachate studies.

MINTEQ calculations indicated that most of the leachate compositions measured for the combined soil/waste form column experiments were out of charge balance, with too many anions present. It was thought that a major cation, perhaps an organic cation that had not been detected analytically, was important in the solutions. The calculations from leachates with reasonable charge 
balances suggest that the leachate composition goes through major changes until they almost completely reflect the composition of the waste stream, with an additional change toward the Hanford groundwater. This could be typical of many diffusion-controlled leaching studies in that the waste form initially has a major influence on the leachate composition. The influence dissipates with continued waste form/soil/ groundwater contact and with reduction in radionuclide diffusion from the waste form.

\section{Idaho National Engineering Laboratory (Phase 1)}

Another successful operating lysimeter program consists of two arrays originally installed by DOE. One array is located at Oak Ridge National Laboratory (ORNL), Oak Ridge, Tennessee, and a second at Argonne National Laboratory-East (ANL-E), Argonne, Illinois. These lysimeter sites are currently supported by the NRC as the "Field Lysimeter Investigations: Low-Level Waste Data Base Development Program." They were designed and are managed by the INEL, Idaho Falls, Idaho. The project (Phase I) was initiated in 1984 to perform field testing of waste forms composed of solidified ion-exchange resin material from EPICOR-II prefilters used in the cleanup of the Three Mile Island Nuclear Power Station (Rogers et al. 1986; McConnell et al. 199()a, 199()b, 1992a, 1992b, 1993). Waste used in the study was significant because of its high loading of radionuclides as well as the use of actual ion-exchange resin wastes of the type used by the nuclear industry.

Wastes used in the study include a mixture of synthetic organic ion-exchange resins as well as a mixture of organic exchange resins and an inorganic zeolite. Solidification agents used to produce the waste forms $(4.4 \times 7.6 \mathrm{~cm}$ cylinders $)$ were Portland type I-II cement and VES. Seven of these waste forms (either cement or VES) were stacked end-to-end and inserted into each lysimeter to provide a 1-L volume of waste. The inventory and approximate radionuclide content of the waste forms used in each lysimeter is found in Table 7. The predominate nuclide was Cs-137 (89 to $94 \%$ ) followed by $\mathrm{Sr}-90$ (1 to $5 \%$ ). There were also significant amounts of Cs-1.34 as well as trace amounts of $\mathrm{Co}-6()$ and $\mathrm{Sb}-125$. Details on waste-form formulation are found in Neilson and McConnell (1986).

There are five lysimeters at each of the two sites. The lysimeters were designed to be selfcontained units that operate for the 20-year life of the study. Each is a right-circular cylinder, $0.91 \times 3.12 \mathrm{~m}$, divided into an upper compartment, which contains fill material, waste forms, and instrumentation, and an emply lower compartment for collecting leachate. The design of the lysimeters can be seen in Figure 22, while Figure 23 shows the placement of the arrays. Four lysimeters at each site are filled with soil, while a fifth (used as a control) is filled with inert silica oxide sand. Lysimeters at ANL-E contain soil

Table 7. Composition of waste forms for INEL-designed lysimeter arrays (McConnell et al. 1990).

\begin{tabular}{llll}
\hline $\begin{array}{c}\text { Lysimeter } \\
\text { number }\end{array}$ & Fill material & Waste form description & $\begin{array}{c}\text { Prefilter } \\
\text { number }\end{array}$ \\
\hline 1 & Soil & Cement with Type A waste & PF-7 \\
2 & Soil & Cement with Type B waste & PF-24 \\
3 & Soil & VES with Type A waste & PF-7 \\
4 & Soil & VES with Type B waste & PF-24 \\
5 ANL-E & Silica oxide & Cement with Type A waste & PF-7 \\
5 ORNL & Silica oxide & Cement with Type B waste & PF-24 \\
\hline
\end{tabular}




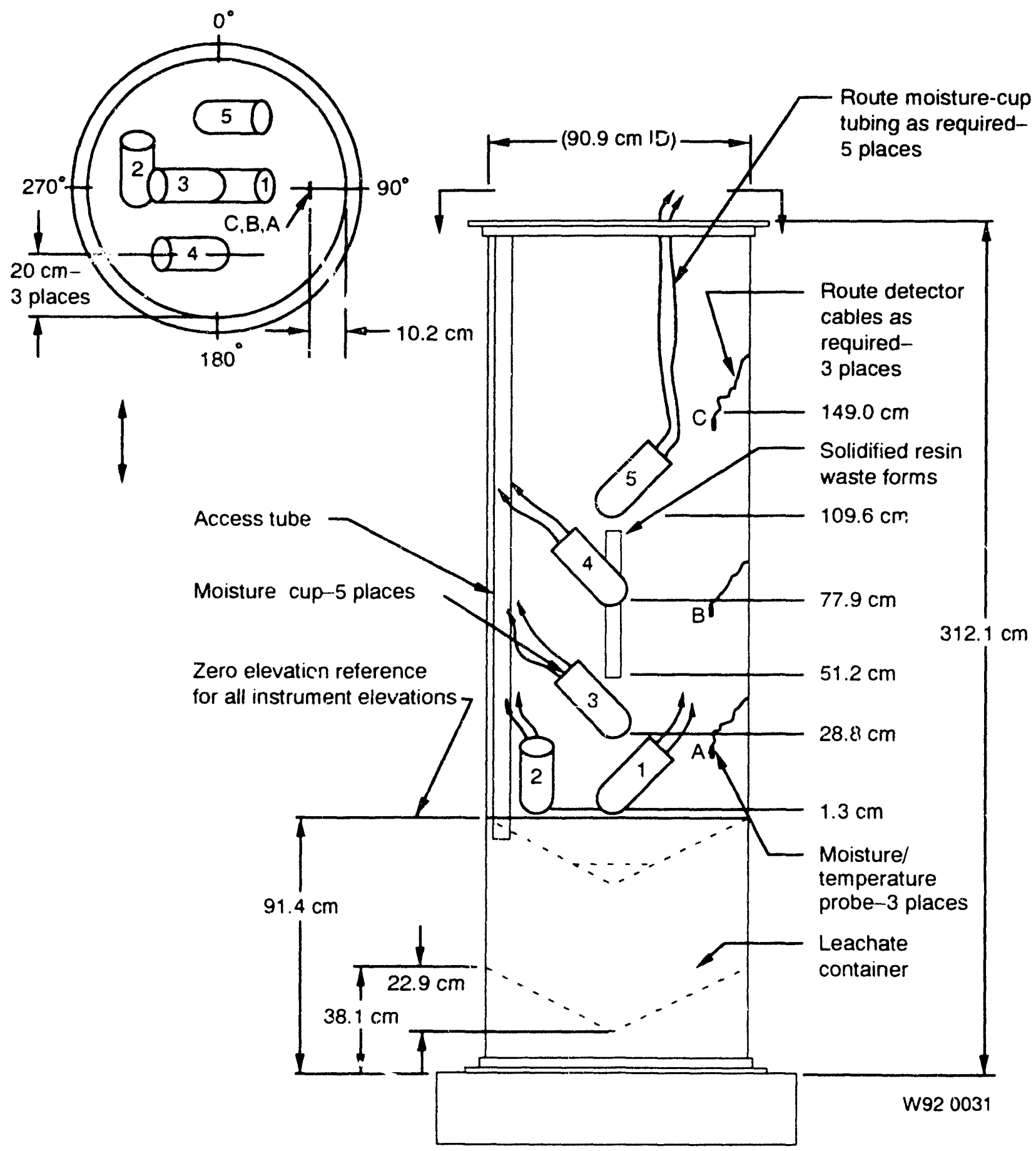

Figure 22. Cross section of INEL-designed lysimeter (McConnell et al. 1990). 

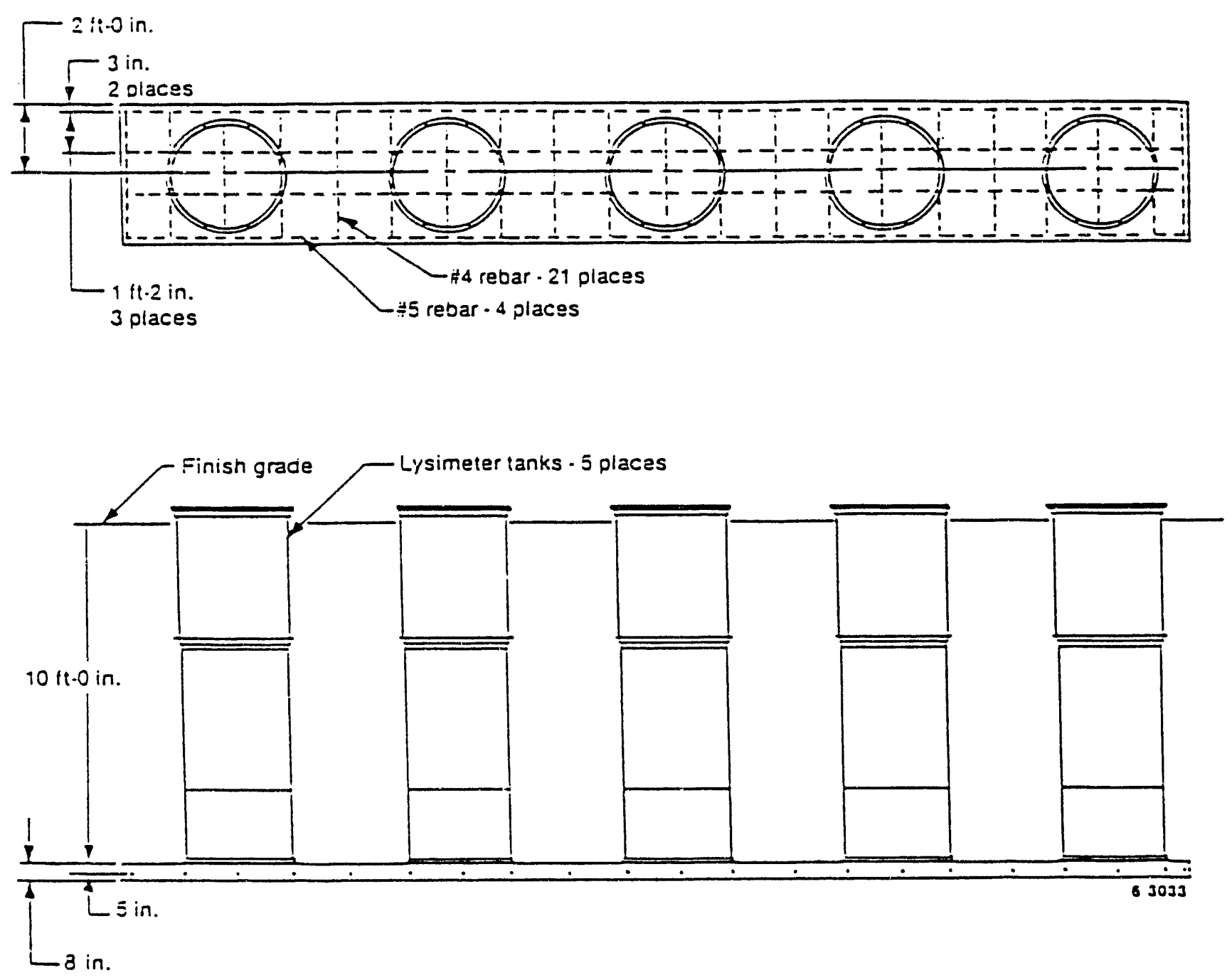

Figure 23. Diagram of INEL-designed lysimeter arrays (Rogers et al. 1986).

indigenous to that site, while the ORNL lysimeters contain soil obtained from SRS. The surface of all the lysimeters are kept clear of vegetation.

Instrumentation in each lysimeter includes live porous-cup soil moisture samplers and three soil moisture/temperature probes. The probes are connected 10 an onsite data acquisition system (DAS), which also collects data from a field meteorological station located at each site. This makes it possible for the continuous recording of soil moisture/temperature at three elevations in each lysimeter along with the complete weather history. Each month, data stored on a casselle magnetic tape are retrieved from the DAS and translated into a PC-compatible disk file. These are subsequently reduced into tabular and graphic displays. These data are of interest because it is possible to determine some of the environmental conditions to which the waste forms are exposed (surrounding soil temperature and soil moisture), which could provide information on wa:te form performance. During the 5 years that the lysimeters have been in operation, it has been noted that some of these probes have begun to fail. Even though the probes were of the highest quality, it appears that they have been damaged by corrosion of the metal parts. In spite of some failures, the probes continue to serve their original purpose of providing some indication of environment surrounding each waste form. As a quality check, the soil moisture in each lysimeter soil column is 
verified each year gravimetrically with soil cores. In addition a neutron probe has recently been employed to verify the soil moisture. Figures 24 and 25 are examples of the yearly moisture and temperature data.

Water samples are normally collected on a quarterly basis from leachate collectors and moisture cups of each of the lysimeters. At each sampling, only water from the leachate collectors $(1 \mathrm{~L})$ and those moisture cups $(0.1 \mathrm{~L})$ closest to the waste forms (a few centimeters away) are generally analyzed for gamma-producing nuclides and the beta-producing nuclide $\mathrm{Sr}-90$. The analysis protocol, however, will trigger the analysis of water from additional cups in a sequential manner if nuclides are found in the first cup. For example, when nuclides are found in the first cup, water from the next cup directly below should be analyzed, followed by the other cups.

It has been found that not all nuclides have been appearing consistently in either the water obtained from the cups or leachate collectors. The nuclide that appears with the most regularity at both ANL-E and ORNL is Sr-90, though the total amount measured is less than $0.045 \%$ of the total inventory in any one lysimeter (McConnell et al. 1993). Consistent significant occurrences of this nuclide have continually been found in all the analyzed cup water at both sites (Figures 26 and 27). Strontium-90 in leachate water from the sand-filled control lysimeters at each site contain amounts of this nuclide several orders of magnilude larger than the soil lysimeters (Figures 28 and 29). This is not in agreement with the cup data from the soil filled units, which show that substantial quantities of $\mathrm{Sr}-90$ are being released from the waste forms. Apparently the nuclide is not free to move through the soil profile.

Cesium-137 was found with regularity in moisture cup samples at both sites. However, in many cases, there is not a consistent appearance (Figures 30 and 31 ). Less than $0.001 \%$ of the total inventory of Cs-1.37 has been detected in any one lysimeter. The nuclide Sb-12.5 was detected early in the control lysimeter at ORNL but has not been found for the past 4 years in that or any other lysimeter.

Apparently, no correlation exists between the type of waste form and the amount of nuclide recovered in the lysimeter water. In the ORNL cups, more $\mathrm{Sr}-90$ has been recovered in lysimeters that contain the cement waste forms than in those that contain VES. However, any conclusions drawn on those data must be tempered with data from an ANL-E lysimeter, which shows greater recovery of $\mathrm{Sr}-90$ from a VES waste form. On an inter-site comparison, larger quantities of Sr-90 and Cs-137 are moving in the ORNL lysimeters than in the ANL-E lysimeters. Soil type and precipitation (environmental factor) appeared to be the controlling factors.

A past evaluation showed that data obtained from NRC data base development lysimeter experiments does have a relationship with performance assessment code parameters (McConnell et al. 1989). The operational lysimeters provide continuous data from the near-field (that area comprised of the waste form and surrounding soil) that directly relates to waste form stability. It was found that information obtained from the data includes the mass balance of released constituents, the solubility of radionuclides in a site specific geochemical system, and an indication of the retardation or dispersion of released constituents during transport to the far-field. Also, soilpore water chemistry (radioactive and inorganic constituents), soil mineralogy, soil water/mineral mass ratio, net infiltration rate, soil profile moisture and temperature, porosity, hydraulic conductivity, and dispersiveness are being or could be extracted from lysimeter output. Such data are invaluable as inputs into process level and performance assessment codes since they represent a field data set that contains complete information that characterizes environmental, hydrogeological, geochemical, and waste form effects.

A collection of data from the two NRC lysimeter arrays were used as inputs to a mixing cell model. This model is a precursor to the models used in the two-dimensional computer code BLT (Sullivan and Suen $\mathrm{i} 9 \mathrm{i} \mathrm{i}$ ). This cude was developed to predict the release of nuclides from a 
Studies of Lysimeters Containing Radioactive Waste Forms

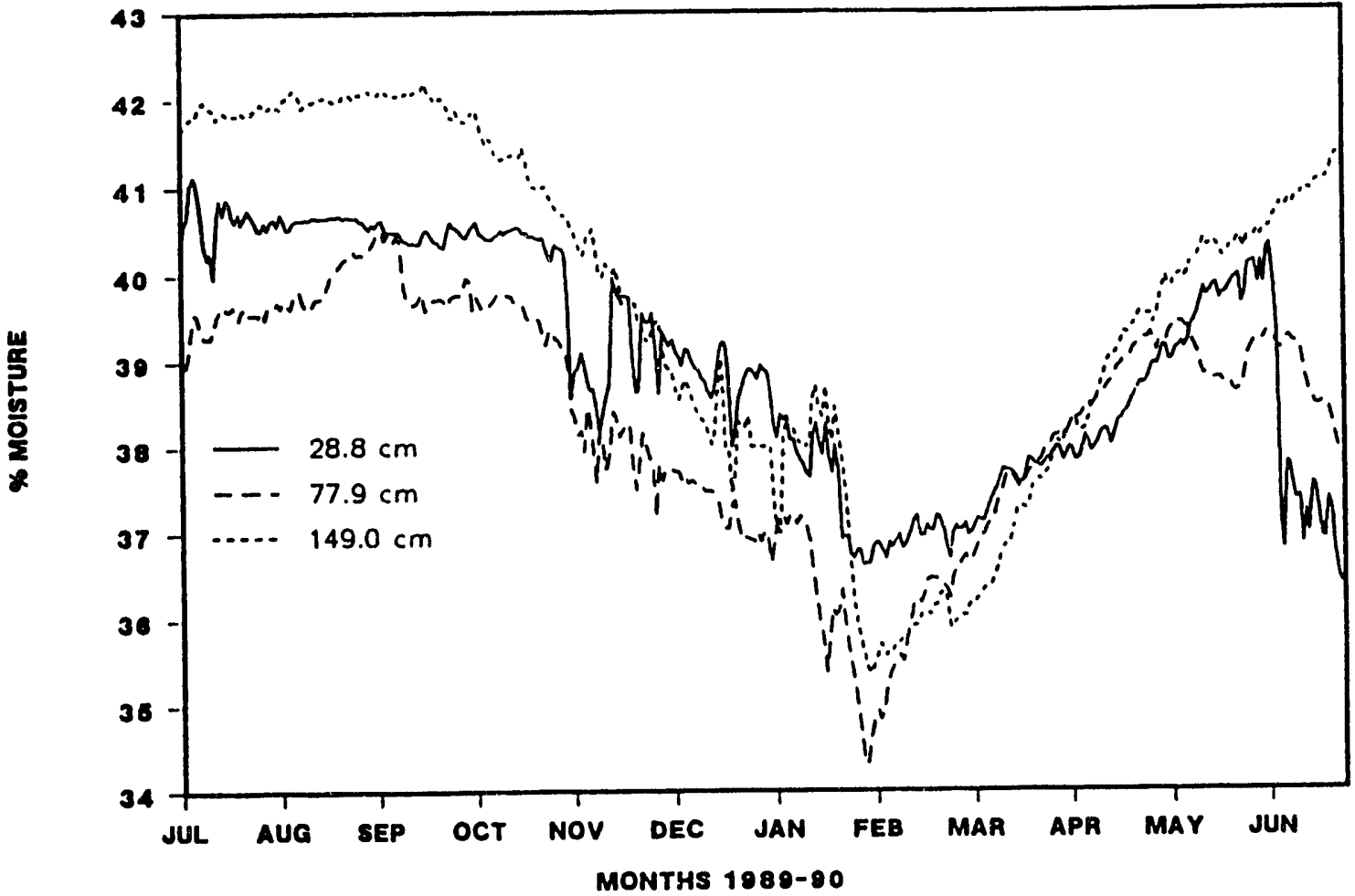

Figure 24. Example of lysimeter soil moisture data from INEL-managed lysimeter array (McConnell et al. 1990).

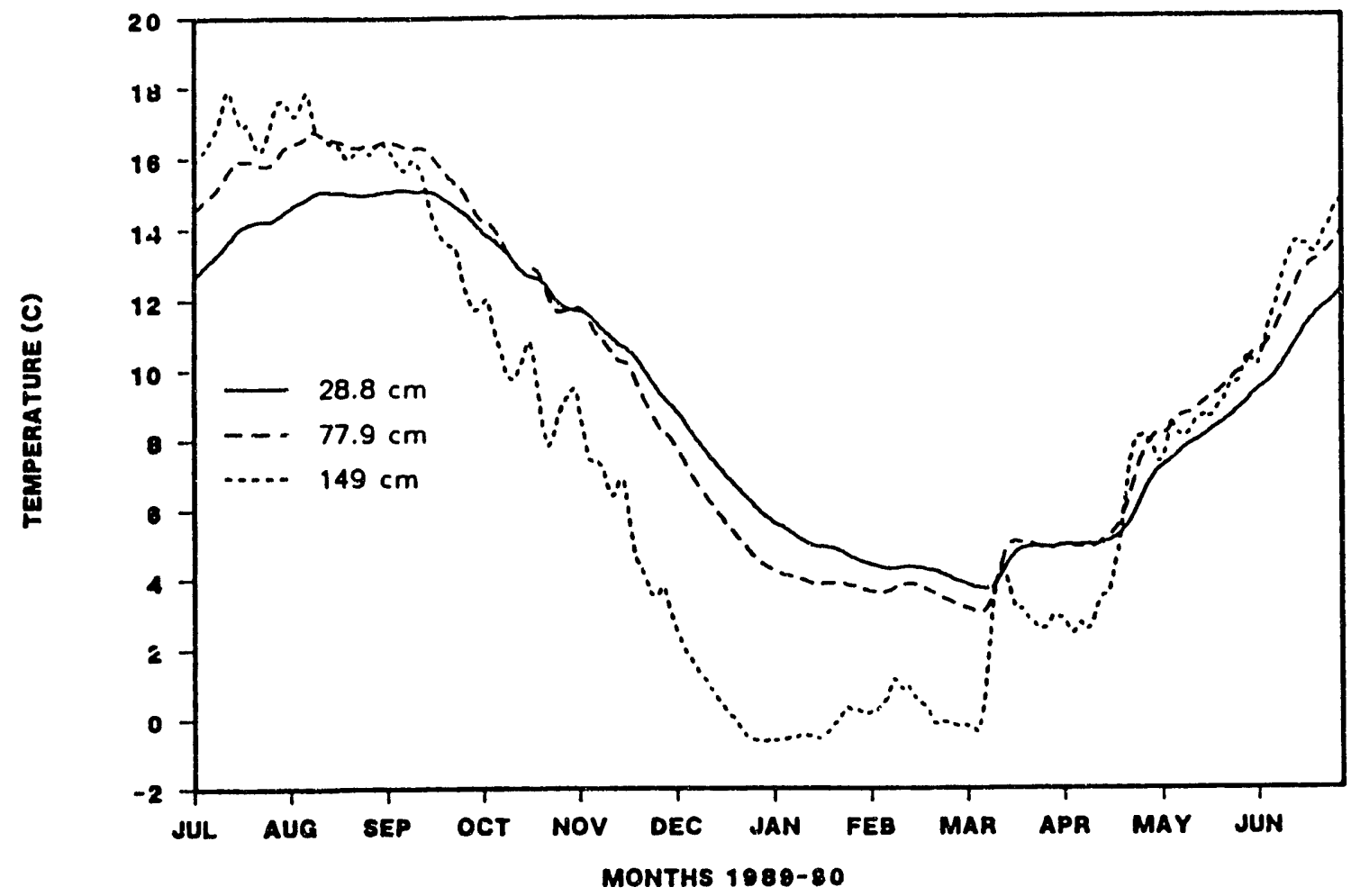

Figure 25. Example of lysimeter soil temperature data from INEL-managed lysimeter array (McConnell et al. 1990). 
Studies of Lysimeters Containing Radioactive Waste Forms

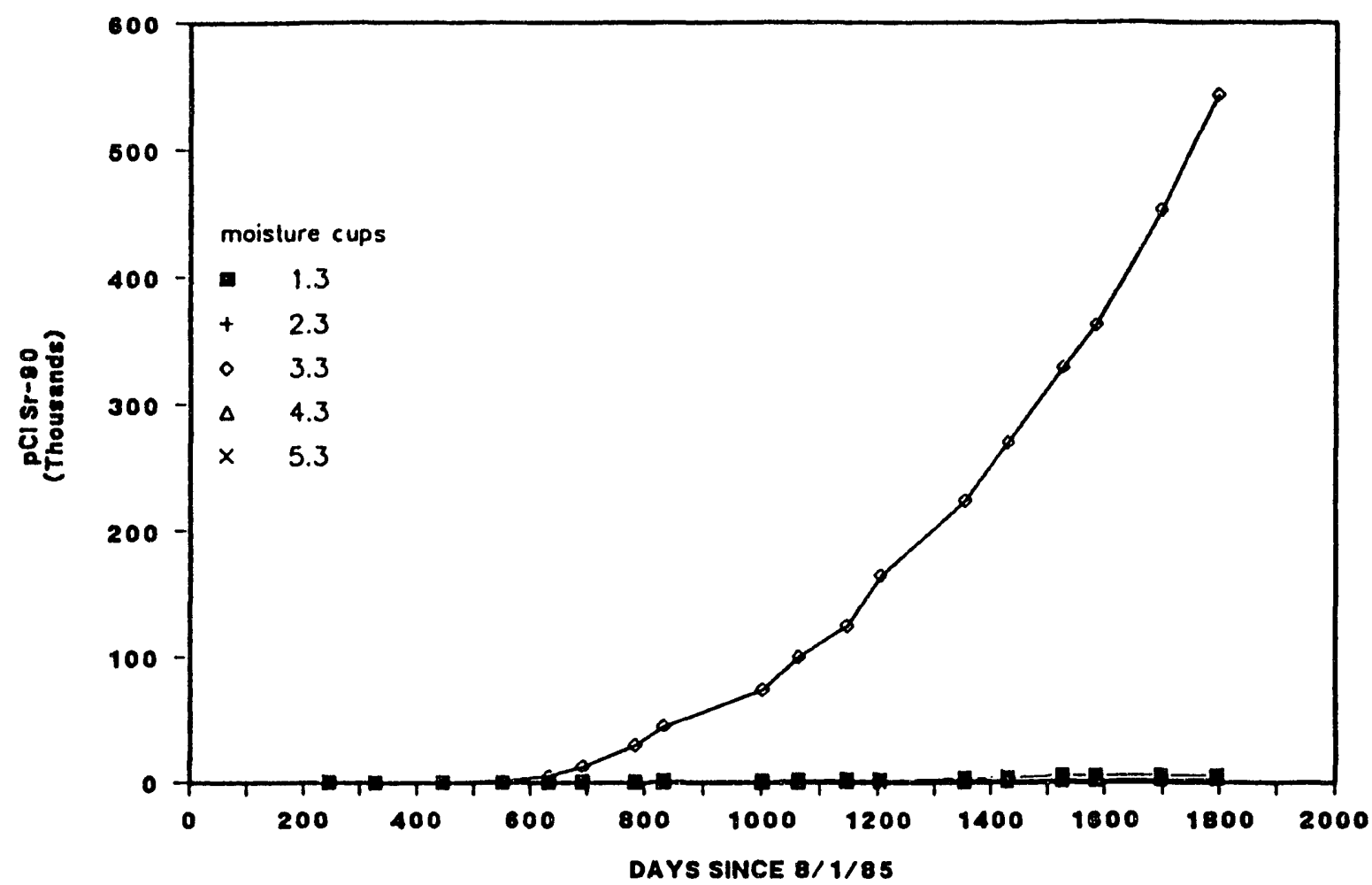

Figure 26. Cumulative Sr-90 from moisture cup number 3 at the INEL-managed ANL-E lysimeter arras (McConnell et al. 1990).

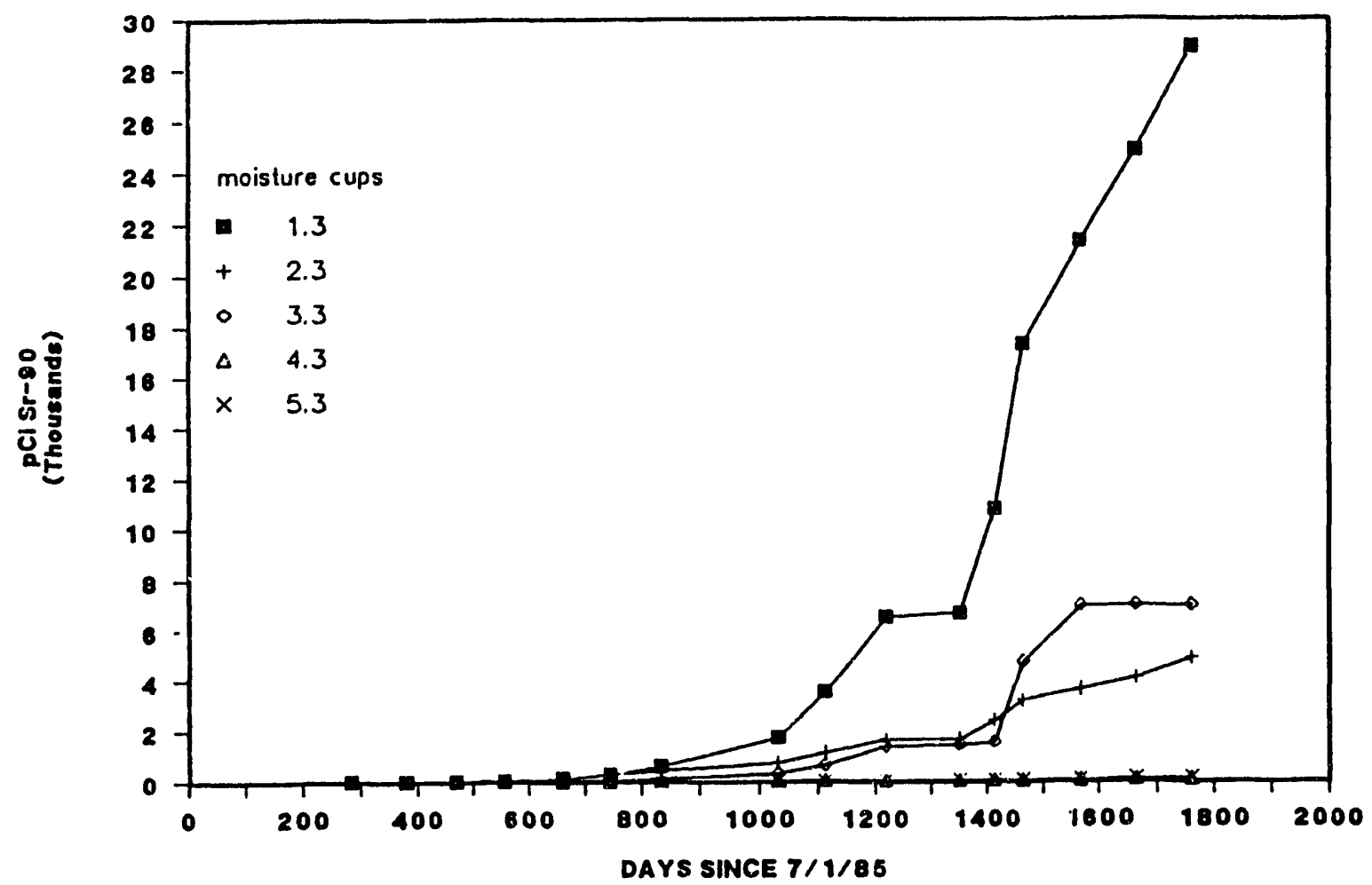

Figure 27. Cumulative Sr-90 from moisture cup number 3 at the INEL-managed ORNL lysimeter array (McConne!! el a! ! 1990). 


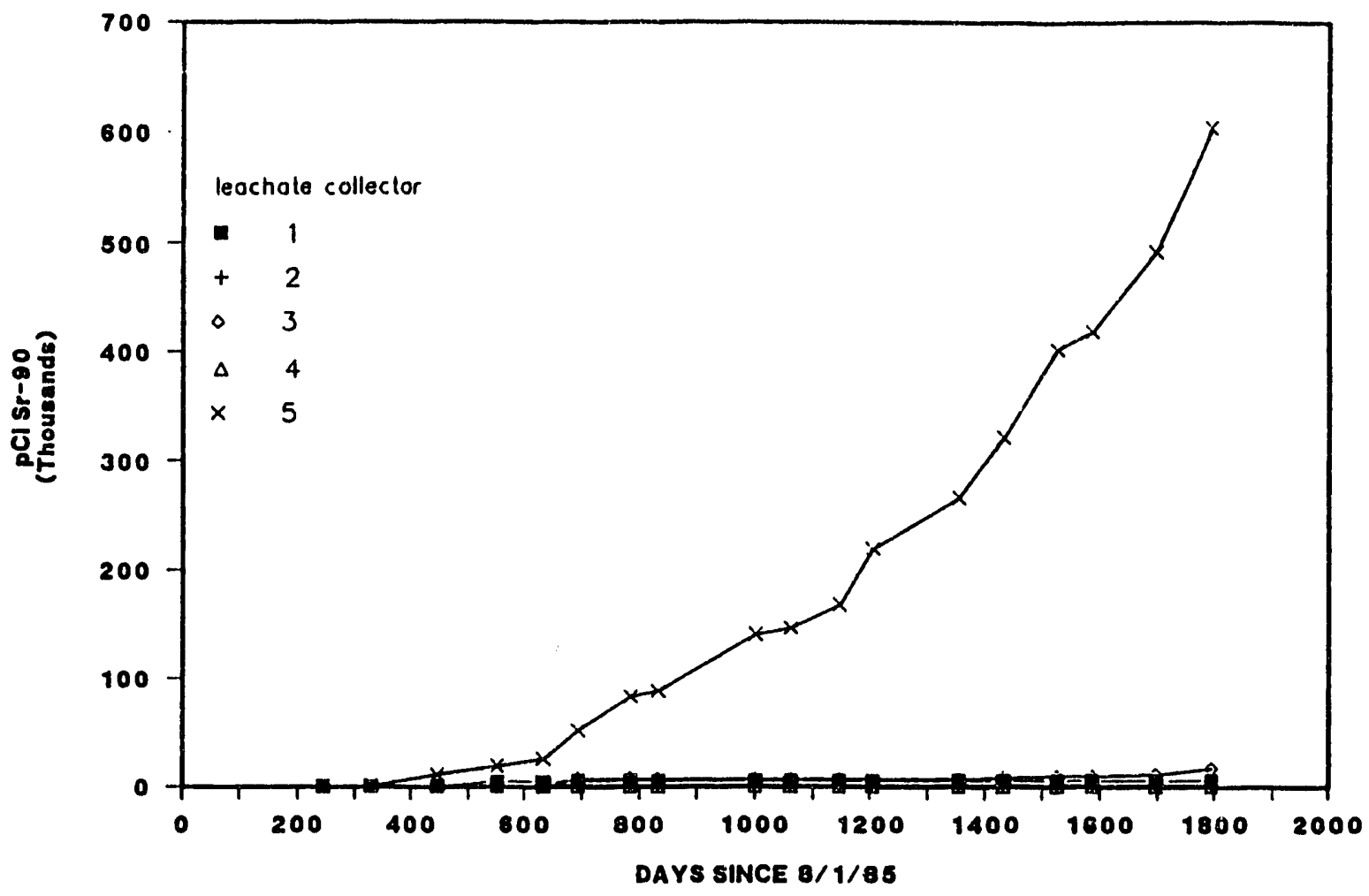

Figure 28. Cumulative Sr-90 from leachate water at the INEL-managed ANL-E lysimeter array (McConnell et al. 1990).

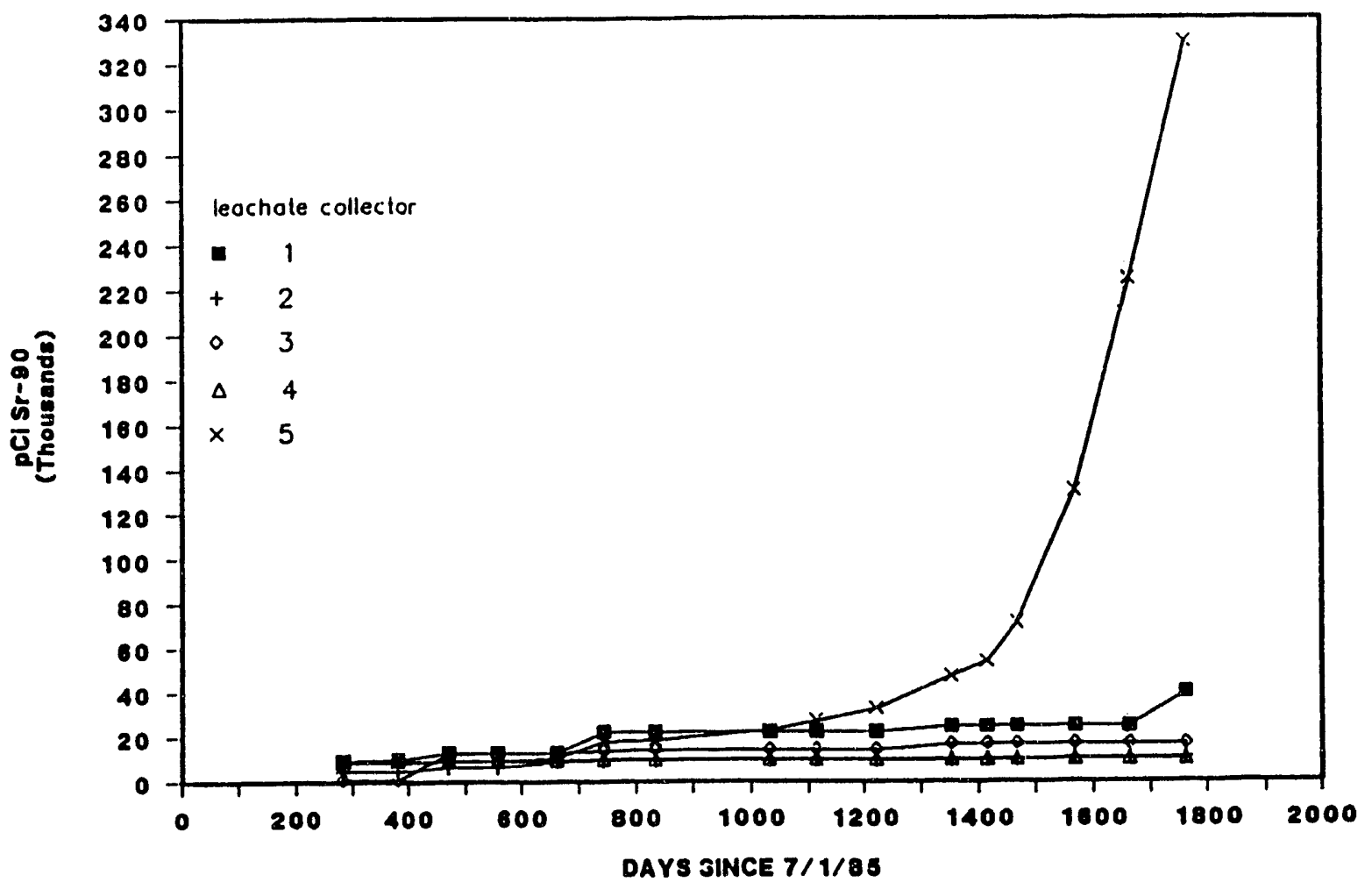

Figure 29. Cumulative Sr-90 from leachate water at the INEL-managed ORNL lysimeter array (McConincll ct al. 1990). 
Studies of Lysimeters Containing Radioactive Waste Forms

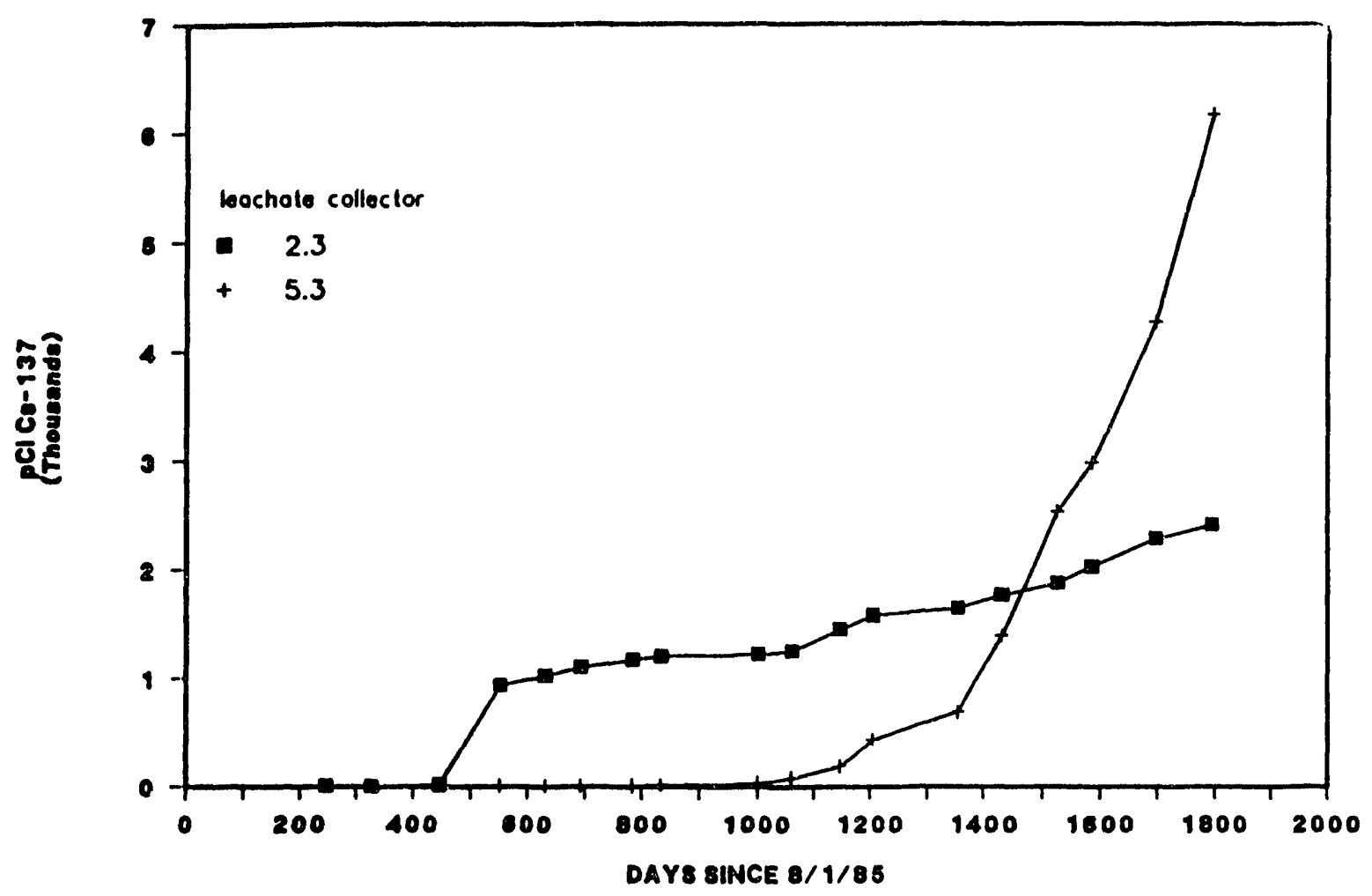

Figure 30. Cumulative Cs-137 from moisture cup number 3 at the INEL-managed ANL-E lysimeter array (McConnell et al. 1990).

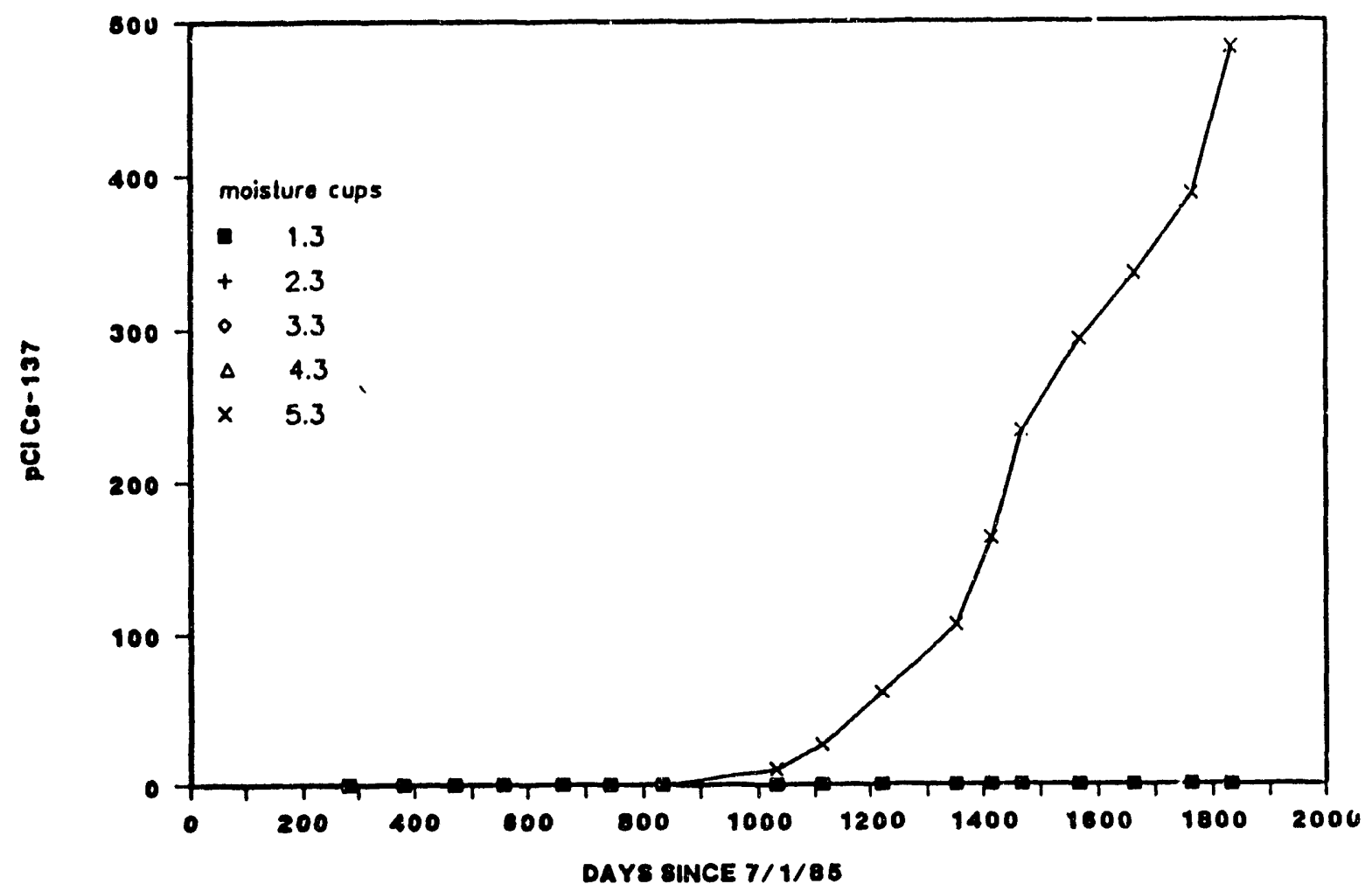

Figure 31. Cumulative Cs-137 from moisture cup number 3 at the INEL-managed ORNL lysimeter array (Míc Comeli ei al. 1990). 
waste form in a failed container surrounded by a porous medium containing a solute. The solute is treated as a well-stirred fluid (i.e., a mixing bath), and solute concentration is calculated using a mass balance that depends on the solute flow rate, the amount of partitioning between the porous medium and solute, the size of the mixing bath, the radioactive decay rate, and the rate of nuclide release from the waste form. Modeling of the waste form is accomplished using a onedimensional finite difference model. BLT has the capability to simultaneously consider three waste form release mechanisms: diffusion, dissolution, and surface rinse limited by partitioning.

Releases of Cs-1.37 and Sr-90) from the NRC experiment waste forms were modeled (McConnell et al. 1992a; 1992b). The most appropriate release process was considered to be diffusion from a cylinder (the shape of the waste forms). The waste form diffusion coefficients for Cs-1.37 and $\mathrm{Sr}-90$ were available from previous studies of EPICOR-II solidified ion-exchange resin waste (Neilson and McConnell 1986). Calculations for the mass balance of the solute concentration required Darcy velocities (volumetric flow rate per area), which were estimated from lysimeter leachate throughput data. Soil/water dispersivity and retardation coefficients $\left(K_{d}\right)$ were estimated from previous published work (Sullivan and Suen 1989; Isherwood 1981). The lysimeter-developed values used for the most important parameters included Darcy velocities, decay constants, and the soil/water retardation coefficients (see Table 8).

Data from a comparison of cumulative Cs-1.37 activity from ORNL-3 appears to give a reasonable prediction (Figure 32 ). From these data, it appears that the mixing bath model of BLT performed adequately for the purposes of this preliminary performance assessment. It pointed out those areas in which additional data (soil dispersivity $K_{d}$ values) will be required in order to use the lysimeter data effectively in performance assessment modeling. These data may be obtained from the soil in the operating lysimeters.

Source term code studies were performed using the data produced through FY-91 by the
ANL-E and ORNL field experiments. The data used in this study were collected from moisture cup 3 , located approximately $23 \mathrm{~cm}$ from the bottom of the waste forms, and from the lysimeter leachate collector, located $61 \mathrm{~cm}$ below the bottom of the waste forms. The radionuclides found to date in the leachate waters have been primarily Cs-1.37 and Sr-90.

The Disposal Unit Source Term (DUST) code was used to model the release of Cs-1.37 and Sr-90) from the lysimeter waste forms. DUST is a one-dimensional code that can model release by a finite difference method or by a mixing cell cascade approach, and has the ability to simultaneously model three different types of release mechanisms: diffusion, dissolution, and surface rinse. The mixing cell model is limited in that it does not take diffusional release into consideration. Therefore, for these simulations, the finite difference model was selected because it is more flexible and capable of handling a variety of different parameters. A further description of the models in the code is given in Sullivan (1991) and Sullivan (1993).

Lysimeter 5 at ORNL and ANL-E were chosen for study of the release of $\mathrm{Cs}-137$ and $\mathrm{Sr}-90$ ) from Portland type I-II cement because releases from other lysimeters were substantially lower and because the data were not sufficient to model. At ANL-E, lysimeter 5 contained resin waste type I solidified in cement; at ORNL, lysimeter 5 contained resin waste type II, which was also solidified in Portland type I-II cement (see Table 9). Diffusional release is believed to be the controlling mechanism for a cement-solidified waste. The waste form diffusional coefficients for Portland type I-II cement were presented in Neilson and McConnell (1986). Measured values were $9.6 \mathrm{E}-10 \mathrm{~cm}^{2} / \mathrm{sec}$ for $\mathrm{Sr}-90$ and $5 \mathrm{E}-11$ $\mathrm{cm}^{2} / \mathrm{sec}$ for $\mathrm{Cs}-137$. The Darcy velocities ranged from $2.59 \mathrm{E}-6 \mathrm{~cm} / \mathrm{sec}$ at ANL-E to $3.6 \mathrm{E}-6 \mathrm{~cm} / \mathrm{sec}$ at ORNL (McConnell et al. 1990b). The soil bulk density values were $1.55 \mathrm{~g} / \mathrm{cm}^{3}$ at ANL-E and $1.60 \mathrm{~g} / \mathrm{cm}^{3}$ at ORNL (Rogers et al. 1986). Moisture content values were calculated using the effective soil porosity and the fraction of saturation values found in McConnell et al. (1992a). In 
Studies of Lysimeters Containing Radioactive Waste Forms

Table 8. Retardation coefficients $\left(\mathrm{cm}^{3} / \mathrm{g}\right)$ of three soils used in INEL-managed lysimeter arrays (McConnell et al. 1992a).

\begin{tabular}{|c|c|c|c|}
\hline Radionuclide & Value used & Lower boundary & Upper boundary \\
\hline \multicolumn{4}{|l|}{ Morley silt loam } \\
\hline Cs- 137 & $10^{3}$ & $10^{1}$ & $10^{5}$ \\
\hline $\operatorname{Sr}-90$ & $10^{0.9}$ & $10^{0}$ & $10^{3}$ \\
\hline \multicolumn{4}{|c|}{$\mathrm{C}$ horizon of Fuquay sandy loam } \\
\hline Cs-137 & $10^{3}$ & $10^{1}$ & $10^{5}$ \\
\hline $\mathrm{Sr}-90$ & $10^{0.9}$ & $10^{0}$ & $10^{3}$ \\
\hline \multicolumn{4}{|c|}{ Unimin silica oxide sand (inert material) } \\
\hline Cs- 137 & $0^{\mathrm{a}}$ & $10^{1}$ & $10^{5}$ \\
\hline \multirow[t]{4}{*}{ Sr-90 } & $0)^{\mathrm{a}}$ & $10^{0}$ & $10^{3}$ \\
\hline & \multicolumn{2}{|c|}{ Decay constants $\left(s^{-1}\right)$} & \\
\hline & Cs- 137 & $7.28 \times 10^{-10}$ & \\
\hline & Sr-90 & $7.57 \times 10^{-10}$ & \\
\hline
\end{tabular}

a. The value assumed for essentially inert material.

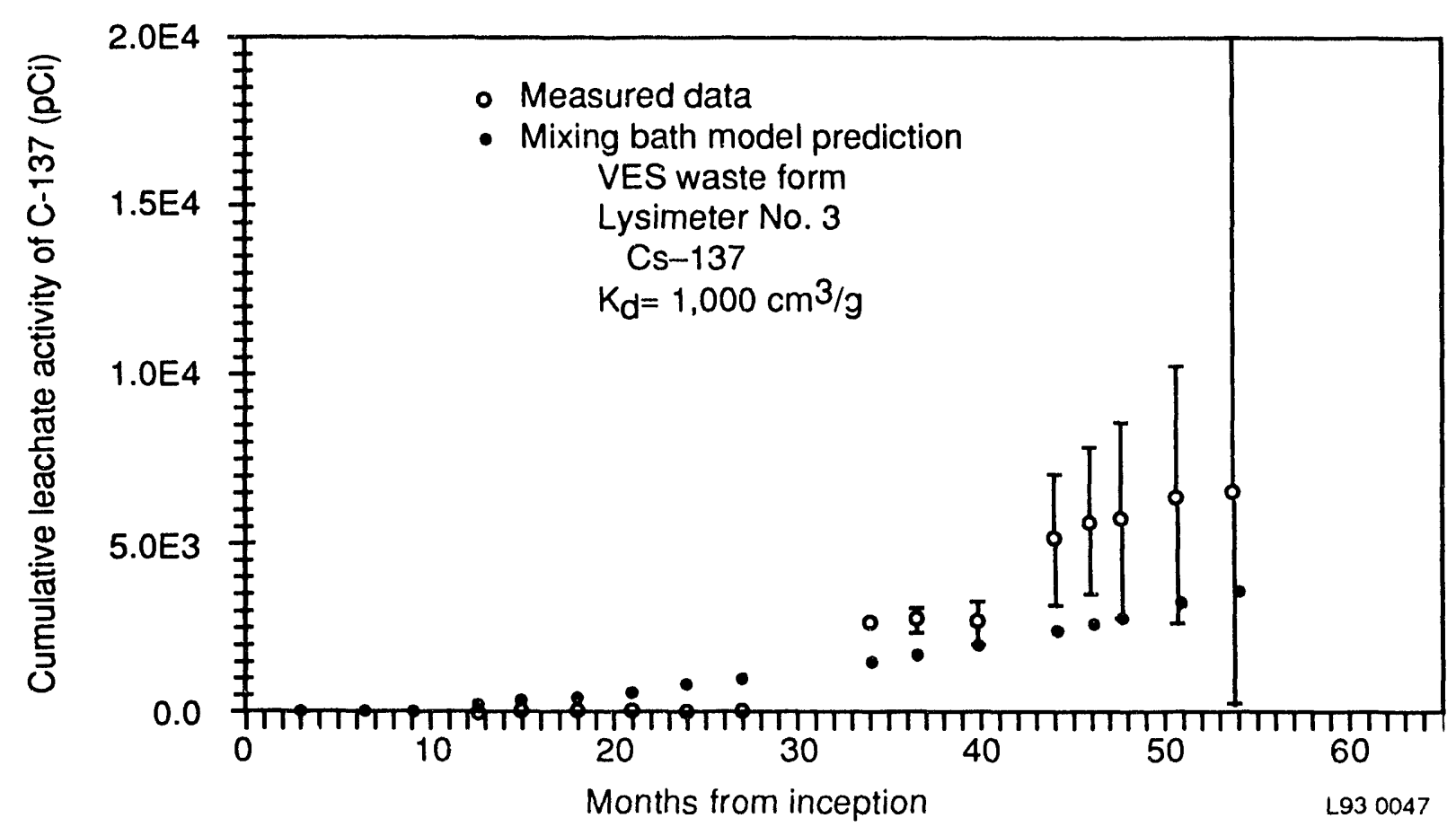

Figure 32. Comparison of C $\$-137$ cumulative activities for measured data at ORNL lysimeter 3 leachate collector (51.2 cm of soil) and mixing bath model prediction (McConnell et al. 1992a). 
Table 9. Total and collected $\mathrm{Ci}$ amounts of $\mathrm{Sr}-90$ and Cs-137 in lysimeter 5 through July 1991 (McConnell et al. 1993).

\begin{tabular}{lccc}
\hline & $\begin{array}{c}\text { Total amount } \\
(\mathrm{Ci})\end{array}$ & $\begin{array}{c}\text { Amount collected } \\
(\mathrm{Ci})\end{array}$ & $\begin{array}{c}\text { Percent } \\
\text { collected }\end{array}$ \\
\hline ORNL Cs-137 & 1.432 & $2.0 \mathrm{E}-7$ & $1.4 \mathrm{E}-5$ \\
ORNL Sr-90 & $3.3 \mathrm{E}-3$ & $8.1 \mathrm{E}-7$ & $2.5 \mathrm{E}-2$ \\
ANL-E-Sr-90 & $1.8 \mathrm{E}-2$ & $1.1 \mathrm{E}-6$ & $5.8 \mathrm{E}-3$ \\
\hline
\end{tabular}

lysimeter 5 at both sites, the moisture content was calculated as $21 \%$. The retardation coefficients $\left(\mathrm{K}_{\mathrm{d}}\right)$ have not been measured for Sr-90 or Cs-137; therefore, they were estimated by fitting the model predictions to the data (Table 8 ). The cumulative leachate activity collected from the lysimeters over the first 6 years of the experiment, which was used to make comparisons to the DUST code predictions, represented less than $0.03 \%$ of the total inventory of $\mathrm{Sr}-90$ in lysimeter 5 at ORNL and ANL-E. At ORNL, the collected amount represented less than $1.5 \mathrm{E}-5 \%$ of the Cs-137 inventory in lysimeter 5 (Table 9).

Concentrations and flux traces were matched to moisture cup 3 and the lysimeter leachate collector. The concentrations and flux traces were taken at 23 and $51 \mathrm{~cm}$ below the waste forms. In this report, the cumulative leachate activity collected $51 \mathrm{~cm}$ beneath the waste form is used as the performance measure. Initial amounts of $\mathrm{Cs}-137$ and $\mathrm{Sr}-90$ varied at ORNL and ANL-E because the control lysimeters contained different resin types. In ORNL lysimeter 5, the type I waste form had a total initial inventory of $3.29 \mathrm{E}-3 \mathrm{Ci}$ of Sr-90 and $1.432 \mathrm{Ci}$ of $\mathrm{Cs}-137$ (Rogers et al. 1986). The type II waste form at ANL-E had a total initial inventory of $1.84 \mathrm{E}-2 \mathrm{Ci}$ of Sr-90 (Rogers et al. 1986). Cesium-137 was not modeled at ANL-E for lack of sufficient releases.

The cumulative activity retrieved from the lysimeters is less than $0.05 \%$ in comparison to the total inventory for Sr-90 and less than $9 \mathrm{E}-5 \%$ for Cs-137 (Table 8). Therefore, either the waste form release rates are much lower than anticipated or transport processes are controlling release through the soil column. At that level, it is possible that random fluctuations (noise) are being seen, and release patterns may not develop for several more years.

Three parameters are known to strongly influence release through the soil column. They are $\mathrm{K}_{\mathrm{d}}$ values (retardation coefficients) and dispersivity, which together control transport from the waste form through the soil column, and waste form diffusion, which controls waste form release rates. Several cases were modeled in which either $\mathrm{K}_{\mathrm{d}}$, dispersivity, or waste form diffusion coefficients were varied to best match the actual release data from the lysimeters.

The domain of the model was extended to $52 \mathrm{~cm}$ below the waste form. This ensures that boundary conditions will not significantly affect the predicted concentrations. Therefore, the results in Figure 33 are obtained using a bottom boundary condition of zero dispersive flux. A concentration trace continued to be taken at the location of the bottom of the soil column, which is $51 \mathrm{~cm}$ below the waste form.

Figure 33 shows the actual data for $\mathrm{Sr}-90$ at ANL-E lysimeter 5, which covers a period of 6 years. In addition, the DUST predictions of 20 years of cumulative leachate activity is plotted in two cases, using dispersive flux boundary conditions. The measured waste form diffusion coefficient of $9.6 \mathrm{E}-10 \mathrm{~cm}^{2} / \mathrm{sec}$ was used. Case 1 has a dispersivity of 8.5 and a $\mathrm{K}_{\mathrm{d}}$ of 24.5. Case 2 has a dispersivity of 0.6 and a $\mathrm{K}_{\mathrm{d}}$ of 10 . Case 2 releases less activity over 6 years than does case 1: however, at 20 years, the amount of activity released by case 2 is an order of magnitude 


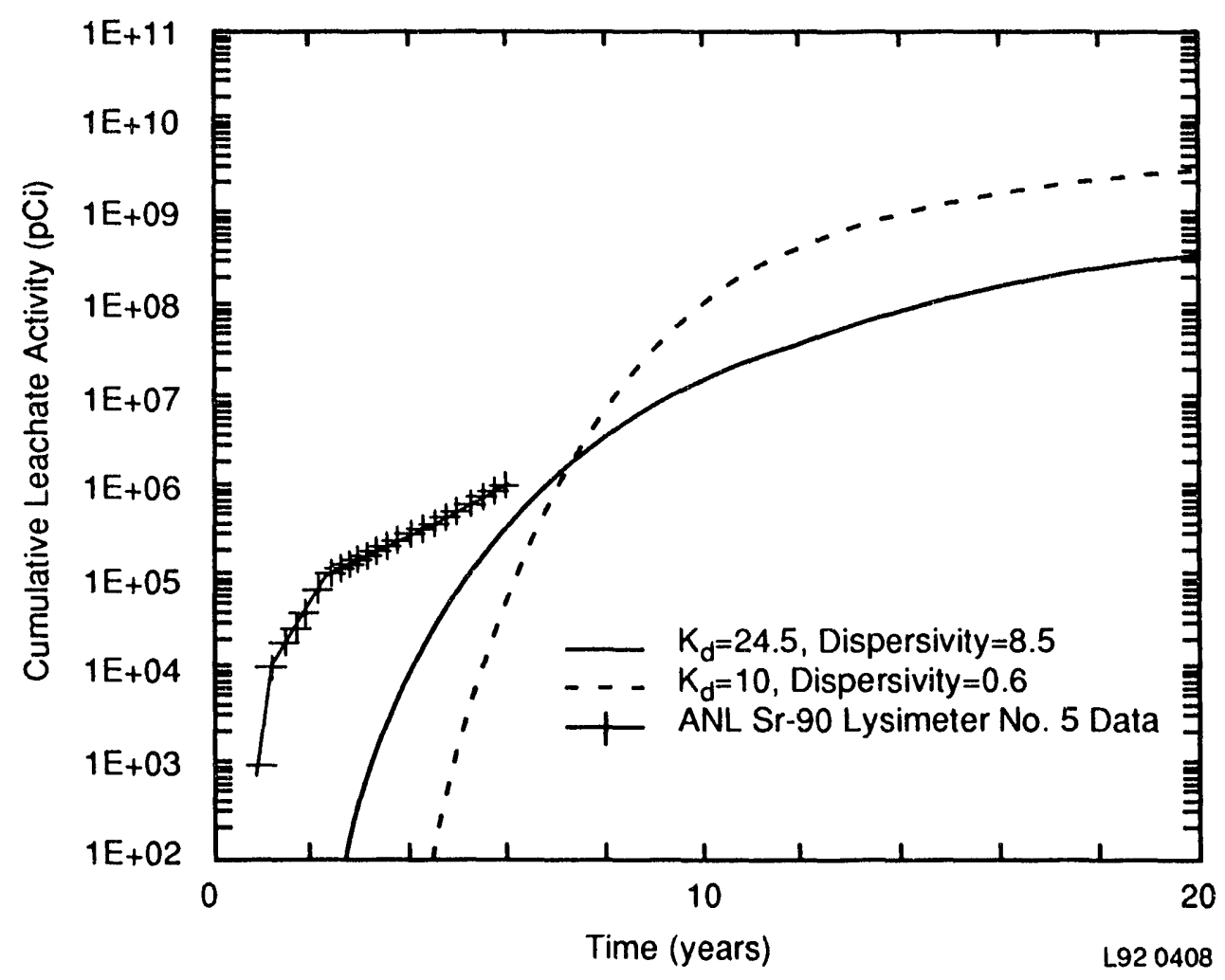

Figure 33. Cumulative release of Sr-90 at ANL-E lysimeter 5 over 6 years, compared with DUST predictions using two sets of estimated $\mathrm{K}_{d}$ and dispersivity values over 20 years (McConnell et al. 1993).

higher than the amount in case 1. Over 20 years, case 2 will have released $33 \%$ of the total Sr-90 inventory, whereas case I will have released $3.3 \%$ of the total Sr-90 inventory. Case 1, also, is a better fit to the actual data at 6 years, indicating a predicted higher dispersivity and $K_{d}$ than previously thought.

\section{Idaho National Engineering Laboratory (Phase 2)}

The Phase 2 lysimeter field experiment is being developed in response to the requirements of the NRC as stated in the NRC Low-Level Radioactive Waste Research Program Plan (O'Donnell and Lambert 1989). The NRC has interest in using lysimeters to help understand and quantify radionuclide transport from representative commercial wastes under unsaturated and saturated flow conditions. Lysimeters can be used to relate laboratory measurements of various radionuclide transport phenomena (such as retardation) to field measurements. This in turn will allow for the validation of radionuclide retardation/transport and source term codes against data obtained under actual environmental conditions. Validation of such codes will strengthen the reliability of performance assessment efforts. Lysimeter-produced radionuclide source term and transport data from radioactive waste originating from nuclear power stations have been given a high priority. The types of wastes that have been designated for evaluation include actual solidified decontamination ion-exchange resin and evaporator concentrate wastes and activated metal wastes, which will be used as the waste forms in new lysimeter systems.

While several other lysimeter experiments reviewed in the report contain waste that originated in commercial nuclear power stations (including the operating INEL/NRC experiment), none provide the diversity of waste type and 
number of both short- and long-lived radionuclides as are planned in this study. The waste types selected contain such short-lived radionuclides as Tc-99, C-14, I-129, Ni-59, and Nb-94. The long-lived radionuclides are so important that their concentration determines the low-level waste classification as directed in Table 1 of 10 CFR Part 61.55, Waste Classification.

Use of these wastes will provide data to help assess the effect of chelating agents and other nonradiological constituents (including chemical compounds) contained in solidified low-level waste on the release and transport of radionuclides. Analysis of results obtained from longterm lysimeter testing should also provide data on the chemical forms of radionuclides leached from power reactor wastes in the presence of natural chelating and complexing agents. These materials are known to occur under actual environmental conditions.

The Phase 2 lysimeter program has been designed to meet NRC needs. These lysimeter studies have been designed to determine the release and transport of radionuclides and chelating agents from certain low-level wastes buried in lysimeters to simulate typical disposal environments. Each lysimeter will contain $8 \mathrm{~L}$ of a single waste. The wastes will be obtained from operating boiling water reactor and pressurized water reactor nuclear power plants. LOMI and CAN-DECON decontamination ion-exchange resin wastes and evaporator concentrates (boric acid and sodium sulfate) will be solidified with Portland cement into 2-L waste forms. Four of those waste forms will be loaded in each lysimeter. Activated metal (spacer grids or shredded end fittings) from a light water reactor plant will be placed loose directly in each lysimeter.

The purposed field testing is intended to expose samples of solidified waste to the physical, chemical, and microbiological environment of both arid and humid sites in typical LLW burial site locations in both the eastern and western United States. As planned, the lysimeters will be used as tools to monitor release of nuclides and chelating agents from the buried waste forms and provide data that will be used to develop and validate mechanistic models that describe these processes. Those data will assist in the accurate deternination of rates of movement as functions of environmental conditions (soil dispersivity and retardation factors, soil and air temperature, humidity, precipitation, wind speed, and soil moisture).

This new Phase 2 experimental design will be based on the successful EPICOR-II lysimeters of Phase $I$ as shown in Figure 22. The waste forms will be larger $(8 \mathrm{~L}$ versus $1 \mathrm{~L})$, and the lysimeter vessel diameter will be increased somewhat from $0.91 \mathrm{~m}$ to $1.22 \mathrm{~m}$. The vessel depth will be increased from $3.12 \mathrm{~m}$ to $4.88 \mathrm{~m}$. Detectors and the data acquisition system will be upgraded to the newest available types to correct minor deficiencies encountered in Phase 1 equipment.

Waste forms used in the fietd test will be actual waste samples solidified in Portland cement collected from operating nuclear power plants and loose, activated, nonfuel-bearing metals obtained from nuclear power plant core fuel bundles. At least four different solidified wastes will be used. Those include LOMI and CAN-DECON decontamination wastes (containing ion-exchange resins) as well as boric acid and sodium sulfate boiling water reactor and pressurized water reactor evaporator concentrates. Spacer grids or chipped-end fittings from light water reactor fuel bundles will serve as the activated metal waste. Individual solidified waste forms will be manufactured onsite at a nuclear power plant by obtaining a cement/waste mixture from the disposal liners during an actual solidification operation. The cement/waste mixture will be poured into cylindrical molds $10 \mathrm{~cm}$ in diameter and $27 \mathrm{~cm}$ high, and allowed to solidify. Enough mixture will be added to produce a waste form with an average volume of $2 \mathrm{~L}$. Sufficient waste forms will be produced to provide placement of four in each lysimeter. In a like manner, enough chipped, activated metals will be manufactured to provide an 8-L volume of material for the lysimeters containing these wastes. The five types of waste forms (two decon wastes, one boric acid, one sodium sulfate, and one activated metal) will be placed in individual lysimeter vessels containing 
site soil. A sixth vessel (the control) will be filled with inert material and will contain one of the waste forms (as a standard).

Experiment sites will be selected in warmhumid, warm-arid, cool-humid, and cool-arid locations. Those locations could be within state compact sites or DOE laboratories. Currently, few state compact sites are in a stage advanced enough to be considered for lysimeter siting. The status of several of the more advanced sites are as follows:

- Warm-humid-Southeast (Barnwell, South Carolina/North Carolina): will close

- Warm-arid-Southwestern (Needles, California): license-approved; land acquisition in progress

- Warm-arid-Texas (Hudspeth County, Texas): license application submitted; land acquisition in progress

- Cool-humid-Central (Boyd County, Nebraska): license application submitted; land purchased; site rejected

- Cool-humid-New York: site selection in progress

- Cool-arid-Northwest (Hanford, Washing(on): operating.

In addition, a number of available DOE labs are suitable:

- Warm-humid-Savannah River National Laboratory, South Carolina

- Warm-humid-Oak Ridge National Laboratory, Tennessee

- Warm-arid-Nevada Test Site, Nevada

- Cool-humid-Argonne National Laboratory-East, Illinois

- Cool-arid-Hanford Operations, Washington.
Lysimeter vessels will be designed as selfcontained units that can be easily disposed at the termination of the field test experiment. Lysimeter vessel design will be a right-circular cylinder ( $1.22 \mathrm{~m} \mathrm{ID} \mathrm{by} 4.89 \mathrm{~m}$ high) constructed of 12-gage, 316-L stainless steel similar to the vessel shown in Figure 22. Internally, the lysimeter vessel will be unequally divided into two sections, the upper being 4,400 $\mathrm{L}$ and the lower 1,050 L. A 1.3-cm, stainless steel pipe will serve as an access to the lower compartment. Soil, instrumentation, and waste forms will be contained in the upper compartment, while the lower will serve as a leachate collector.

Reasons for choosing this size of lysimeter vessel are the following:

- It is large enough to allow for unrestricted flow of soil-water around the waste form while maintaining a temperature equilibrium, yet is small enough to be casily transported and installed at the state compact sites and later removed and disposed

- Edge effects in soil water flow are minimized in the area of the waste form

- It provides room for efficient placement of waste forms and instrumentation

- Soil shielding is sufficient to reduce exposure to radiation at the soil surface to no greater than background levels

- It allows sufficient depth to prevent freezing of the waste forms at all proposed sites.

As designed, the leachate collector is an integral part of the lysimeter and, as noted previously, is vented to the surface by a stainless steel tube mounted on the internal wall of the lysimeter shell. The tube terminates inside the leachate collector at the lowest elevation. The upper end of the lube will protrude from the surface of the soil and will be fitted with a quick disconnect hose connection. With a hose connected, the vent pipe can then be used for the withdrawal of leachate from the collector. There is then a two-fold purpose for the leachate collector: (a) to facilitate gravitational drainage of water stored in the soil 


\section{Studies of Lysimeters Containing Radioactive Waste Forms}

column of the upper compartment, and (b) to provide sufficient storage capacity for the collection of a time-integrated sample of water that has moved out of soil storage.

Soil water is typically recovered from a soil column through the use of vacuum devices. Such devices, commonly called soil water samplers, suction lysimeters, or suction candles, are typically composed of a PVC pipe body fitted with a porous cup. The standard dimensions for devices are generally $4.83 \mathrm{~cm}$ OD by various lengths $(15.2 \mathrm{~cm}$ and longer). Porous cups are normally made of ceramic, though porous Teflon is also available. Those NRC lysimeters currently in operation have samplers that are $20.5 \mathrm{~cm}$ long and have a $2.69-\mathrm{cm}$ OD with a porous Teflon cup. Because Teflon is a nonwetable material, samplers with Teflon cups must be installed into pockets of silica flour. These pockets aid in the pooling of soil water so that it is more available for removal by the sampler. As is evidenced by several years' worth of data from the presently operating NRC lysimeters, these samplers provide satisfactory service under the soil moisture condition at those humid lysimeter sites. In drier environments, Teflon is not the material of choice for the porous cup. Because it is hydrophobic, Teflon will not attract water from the surrounding soil even in the presence of the silica flour. It will be necessary, therefore, 10 select either a different material for the porous cup (such as ceramic) or a different type of sampler. If ceramic cups are shown to be the material of choice, it will be necessary to conduct some laboratory work to determine if the ceramic material would interfere with the free movement of the nuclides of interest.

There have been innovative attempts by others to develop moisture samplers that do not require the use of porous cups. Two such devices include a porous hollow fiber device and a fiberglass wicking system. The hollow fiber device is custom-constructed from a bundle of 12 polyvinylidene fluoride hollow fibers $0.1 \mathrm{~cm}$ in diameter and $30 \mathrm{~cm}$ long. The bundled fiber ends are then sealed into the open end of a $1.3-\mathrm{cm}$ tube. As far as is known, these devices are not commercially available and would have to be constructed in-house. While their application has been in an arid environment, the conditions in which they were used was with an irrigated soil, and the vacuum applied to the system to draw water was only 3 psi. Before these devices would be considered for installation into a lysimeter, it would be necessary to find a supplier and then demonstrate the ability of such a device to withdraw water from a nonirrigated arid soil system. The fiberglass wicking system does not depend on externally supplied suction to draw water from the soil. The wick itself supplies suction of about I psi. This method is new and is still in the experimental stage. It is anticipated, however, that such a method would not operate well under dry conditions.

The NRC lysimeters currently in operation use a combination soil moisture/temperature probe that consists of stainless steel cells made up of two metal plates separated by a fiberglass binding. The cells are 2.5 by $4 \mathrm{~cm}$ and include a thermistor. When installed, these cells were the state-of-the-art devices for the continuous, remote determination of soil moisture and temperature. While the current devices are still providing data on soil moisture, there is some question of their longevity. A new generation of soil moisture detection equipment designed for remote applications has recently been introduced on the market. The system uses the principle of time domain reflectometry (TDR). It works by determining the dielectric constant of a soil by measuring the transit time of an electromagnetic pulse launched along a pair of parallel metallic rods (wave guides) embedded in the soil. In the frequency range of $1 \mathrm{MHz}$ to $1 \mathrm{GHz}$, dielectric constant is a function only of volumetric moisture content and not other physical properties of a soil. With the proper electronics (an internal microprocessor) it is possible to convert the detected dielectric constant into a percent volumetric moisture content. These data can then be conveniently stored on a continuous basis by a data logging system. When a TDR system is used, the extensive calibration required with other moisture devices is no longer necessary. In addition, the probes can be manufactured of material that is highly resistant to deterioration in a soil matrix; 
thus. the longevity of the probes is expected to match tiat of the lysimeter syster.. One such system is available commercially and is compatible with the planned data acquisition system.

The current TDR system does not provide a method for determining soil temperature. It will therefore be necessary to provide at thermocouple probe. which will be selected from standard. commercially available units.

All lysimeter sites will be supplied with field meteorological stations. These stations consist of a tipping-bucket rain gauge (with wind screen and healing 10 measure the water content of snow). wind speed sensor. wind direction sensor, and air lemperature/relative humidity probe. All equipment except the rain gauge will be mounted on at 3 -m. electrically grounded tripod localted ad jacent 10 each lysimeter array. Data from each instrument $n$, I be processed and stored in real time by a data acquisition system (DAS).

Data from the moisture and temperature probes within each lysimeter. as well as those from the weather station. will be collected by, processed in. and stored in a DAS. The DAS will be designed to provide remote retrieval of stored data. Each site will be directly accessible via a telephone link that will allow downloading of stored DAS data on a periodic schedule. With this system. data from each site will be automatically downloaded directly into a computer at the INEL where it will be translated and stored for later processing. The remote operation will allow for reasonable access 10 the DAS for both data acquisition and system trouble warning. This feature is essential since the remote sites will be visited only once each quarter for water sampling purposes.

Five lysimeters at each field site are to be filled with soil: the remaining one will be a control filled with an inert material. Soil for fill will be local soil probably from the bore hole for the lysimeter) tha! hac heen hoth phycically and chemically characlerized. It will be screened to pass a $1.3-\mathrm{cm}$ mesh and then mixed to ensure homogeneity (no effort will be made to layer the soil in horizons).

From past experience, it has been found that pure silica oxide sand satisfies the requirements for the inert fill material (Rogers et al. 1986). A fine/medium sand from the Unimin Corporation in Troy, Illinois, will be used. Because this sand has the proper density, provides rigid support for probes, and retains moisture, it has the necessary physical characteristics for use in control lysimeters.

Another item that will be an integral part of the fill material is a layer of a support/filter fabric. This material (DuPont "Typar" style 340) will be placed at the interface of the soil or sand and a gravel bed. Placing the fabric at the bottom of the soil profile will (a) improve separation of the soil and the drainage aggregate, (b) prevent clogging of the drainage aggregate with soil fines, and (c) promote adequate drainage of the lysimeter soil/sand. Tests with this particular material have shown that it sorbs inconsequential amounts of the radionuclides Ce-144, I-131, Ru-103, Sr-85, Cs-137, and Co-60. Its sorptive capacity for other nuclides can also be determined.

The gravel bed in each lysimeter provides support for the Typar fabric and is intended to promote drainage of water. Gravel will be prevented from entering the leachate compartment by a screen covering the drainage port. A $0.64-\mathrm{cm}$ granitic pea gravel has been shown to work well (Rogers et al. 1986). Other types could be used if they are shown to be nonsorbing. All gravel will be prewashed to remove fines.

\section{Oak Ridge National Laboratory}

The use of a different strategy for disposing of uranium (iJ) production wastes from the Y-12 Plant at ORNL prompted the need for data on the movems $\mathrm{nl}$ of $\mathrm{U}$ in a burial site environment (Clapp et a'. 1988). To provide data on how $U$ behaves under burial conditions, a uranium lysimeter demonstiation project was begun with support from the Y-12 Plant at ORNL.

The study was designed to investigate the leaching characteristics of waste types containing 
depleted U. Twenty lysimeters were installed at a site west of the Oak Ridge Y-12 Plant. The lysimeters were designed to provide leaching data for 50) years. Three replicates of each waste type were to be leached in separate lysimeters under natural rainfall conditions. The remaining lysimeters were to be used for special lests (e.g., accelerated leaching and landfill simulation). Each lysimeter is $3 \mathrm{~m}$ high and $2.4 \mathrm{~m}$ in diameter and is designed to contain about $8.3 \mathrm{~m}^{3}$ of waste (Figure 34 ). The volume of leachate generated, the concentration of $U$ in the leachate, and other leachate characteristics (e.g., total organic carbon. $\mathrm{pH}$, and dissolved oxygen), can be moni: ored in order to reveal more fully how these factors affect the leaching of uranium under landfill conditions. It is planned that these data, in conjunction with pathway models, will be used to calculate impacts on the environment arising from the disposal of $U$ containing wastes. Currently, it is planned to load just three vessels using the typical production trash from the Y-12 Plant (Gates et al. 1993). Groundwater will be applied over the waste surface at a rate of up to five times the natural local rainfall. The lysimeter facility has been completed and currently awaits loading of waste and detectors.

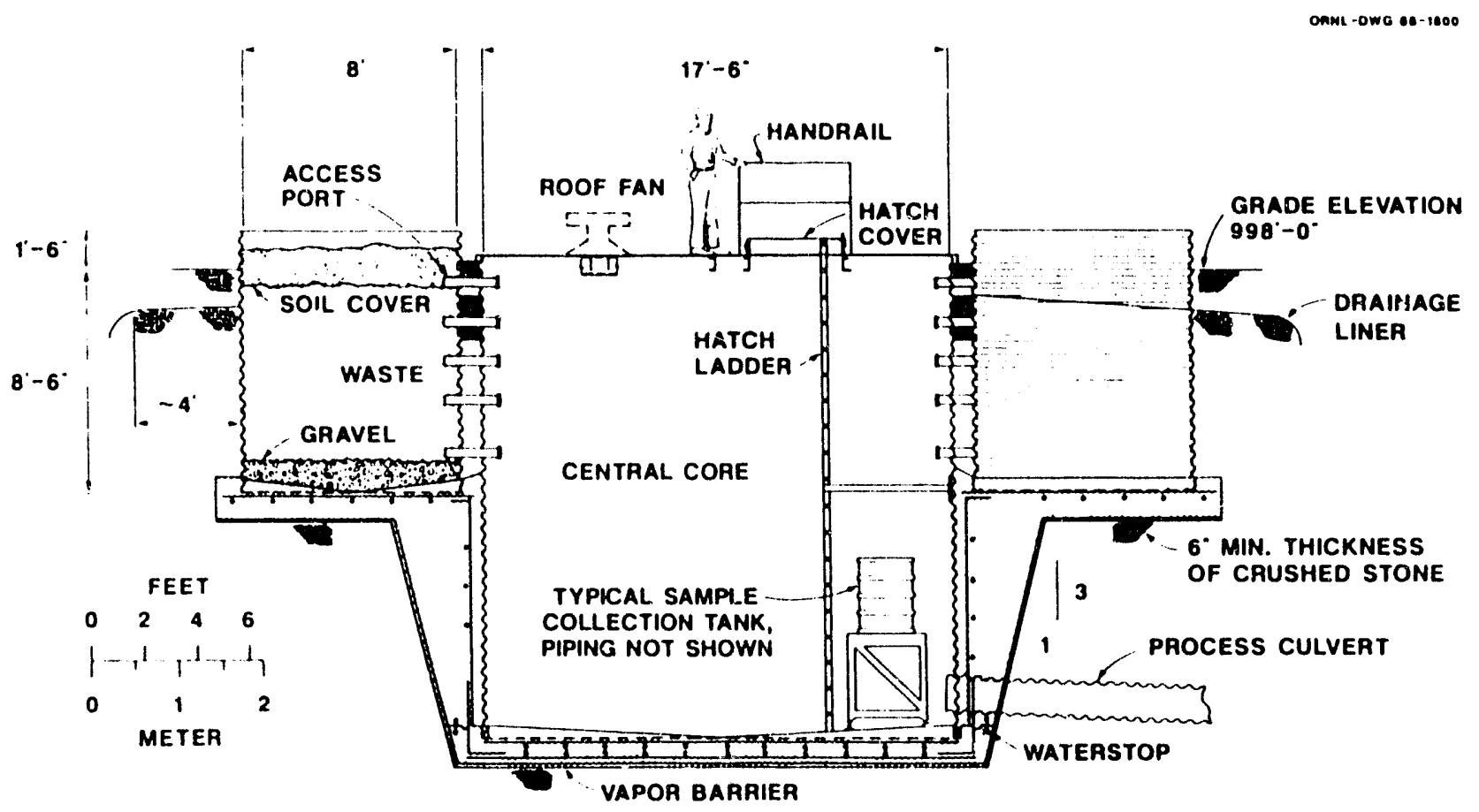

Figure 34. Diagram of (ORNL uranium lysimeter (Clapp el al. 1988). 


\section{RADIONUCLIDE TRACER STUDIES}

\section{Whiteshell Nuclear Research Establishment}

Four studies were conducted by the Whiteshell Nuclear Research Establishment for Atomic Energy Canada, Ltd. Three of the studies were conducted to determine to what extent technetium (TC) moves in soils. These studies are described in Sheppard et al. (1983) and in Sheppard and Sheppard (1984). The fourth study was conducted to determine the transport of $\mathrm{C}-14$ in soil (Sheppard 1990).

The first study was carried out in disturbed soil mixed with 2.5 w1. \% wood sawdust and repacked into $15 \mathrm{~cm} \times 40 \mathrm{~cm}$ columns (lysimeters), which were subsequently placed in the field (Sheppard and Sheppard 1984). Technetium, as $\mathrm{NH}_{4} \mathrm{TcO}_{4}$, was uniformly dispersed into a $4-\mathrm{cm}$ layer of soil at a concentration of $1 \mu \mathrm{g} \mathrm{Tc}-99 / \mathrm{g}$ dry soil for a total of $440 \mu \mathrm{g}$ Tc-99 per column. The contaminated layers were placed in separate lysimeters at depths of $16-20,24-28$, or $32-36 \mathrm{~cm}$ below the soil surface.

Each of the treatments was replicated at least four times for a total of at least 12 lysimeters. Methods on placement of the lysimeters in the field were not provided. Apparently, the lysimeters were constructed so that the water table could be held constant at $26 \mathrm{~cm}$ from the soil surface in half of the lysimeters (it is assumed that this refers to two of the four replicates in each treatment). The water table was allowed to fluctuate weekly between 18 and $34 \mathrm{~cm}$ in the other lysimeters (information on how the water table was maintained was not provided).

All of the lysimeters were planted with barley. After 53 days, the barley had grown to head and samples were obtained for analysis of Tc-99 in the shoots. At that time, the soil columns were sectioned into $2 \mathrm{~cm}$ slices and analyzed for total $\mathrm{Tc}-99,0.02-\mathrm{mol}^{2} \mathrm{~L} \mathrm{CaCl}_{2}$ extractable $\mathrm{Tc}$ and $0.5-\mathrm{mol} / \mathrm{L} \mathrm{NaHCO} \mathrm{N}_{3}$ extractable Tc.

Data from the soil total Tc-99 analyses showed that it had a tendency to migrate toward the soil surface. No extractable Tc was found in the soil. The upward movement of Tc was not explained, though it was noted that there was an upward flux of water to supply the demand for evapotranspiration. Those soils that experienced reducing conditions showed a lower mobility of Tc. Apparently, the water table interface did not act as a barrier to the upward migration of Tc, but did cause a discontinuity in the degree of sorption.

The second study by Sheppard and Sheppard (1984) used 80 undisturbed soil cores $(5.1 \mathrm{~cm} \times 52 \mathrm{~cm})$ that were placed into sleeves of an unidentified material (assurne some plastic). These units (lysimeters) were then placed in the ground to maintain natural soil temperature and rainfall conditions (Figure 35 ). The work was divided into two studies: cores that were recovered after 1 year and those that were to remain for 4 years. Those cores used in the 1 year study were amended with $\mathrm{Tc}-99$, as $\mathrm{NH}_{4} \mathrm{TcO}_{4}$, labelled with Tc- $95 \mathrm{~m}$, while those of the 4-year duration were amended only with Te-99. In one-half of each group, the addition of Tc was made below the itter layer, while the rest were amended in the lower $B$ horizon at about $45 \mathrm{~cm}$ below the surface.

In the cores spiked near the surface, leachate was sampled after each significant rainfall. Preliminary results showed that an average of $6.2 \%$ of the Tc- $95 \mathrm{~m}$ was removed after the first spring snowmelt. After an additional eight leachate events from April 1984 through July $198471 \%$ of the original $\mathrm{Tc}-99 \mathrm{~m}$ remained in the cores. The amount of precipitation $(30.7 \mathrm{~cm})$ passing through the cores during this period represented 19 pore volumes. Data on the movement of Tc added near the bottom of the cores wert to be obtained at the end of the study.

Sorption experiments carried out with soil from the various soil horizons showed that the mineral horizons had $\mathrm{K}_{\mathrm{d}}$ values $<0.05 \mathrm{~mL} / \mathrm{g}$. These values were not thought to be different from zero. The $K_{d}$ value for the litter horizon was $1.1 \pm 0.2 \mathrm{~mL} / \mathrm{g}$. 


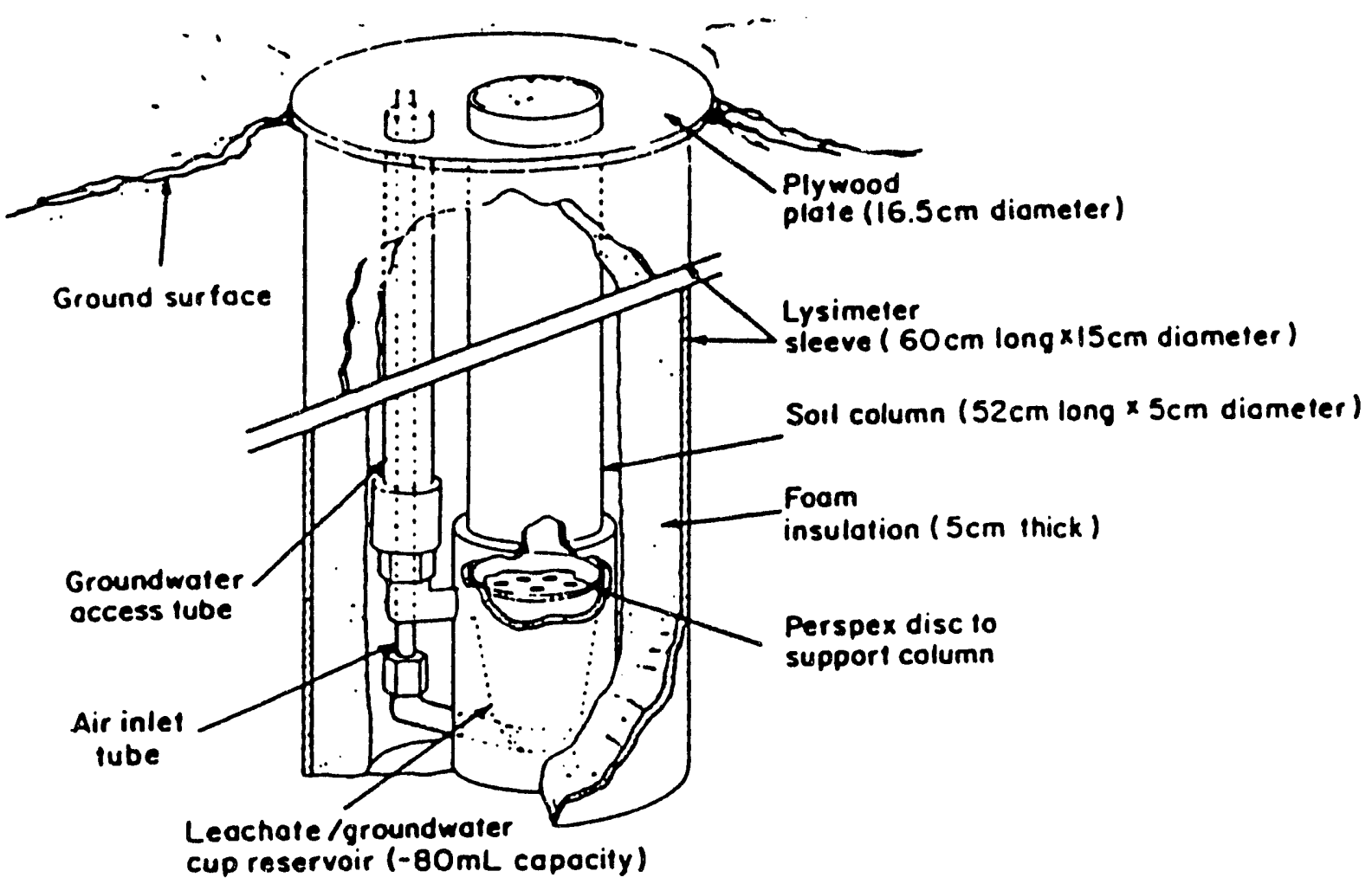

Figure 35. Cut-away view of soil core and leachate/groundwater cup assembly (Sheppard and Sheppard 1984).

Soil cores used in Sheppard's third study (Sheppard et al. 1983; Sheppard and Sheppard 1984) were undisturbed cores of peat. Apparently, only three cores were used. They were $28.5 \mathrm{~cm} \times 40 \mathrm{~cm}$ and were obtained from depths of $0-40$ and $40-80 \mathrm{~cm}$ from one site, and $0-40 \mathrm{~cm}$ from another bog site. The cores were confined in large, round plastic containers (same size as cores) and were amended at the bottom with Tc, I, Np, and $U$. The enclosed cores were placed back into their natural habitat. Similar cores were spiked with tritiated water to follow upward movement of groundwater. Water samples were withdrawn from the core surfaces for analysis to determine surface breakthrough of the Tc.

Early results showed that tritium was detectable at the core surface within 2 weeks with a peak of activity within 6 weeks. At that time, no Tc-95m was detected. Apparently, no analysis was made to determine the presence of the other nuclides.
Based on the initial results of the three studies by Sheppard, it was concluded that Tc mobility is lower in soil under reducing conditions, but that the water table interface itself is not a barrier to the upward migration of Tc. In addition, despite very low measurable $K_{d}$ values for sand (as measured in the laboratory), an undisturbed sandy profile retained $71 \%$ of Tc added below a surface litter layer. Finally, no Tc migrated to the surface of peat cores that were experiencing an upward movement of groundwater after 3 months. Such data indicated that the organic composition of peat soils could strongly affect the migration of $\mathrm{Tc}$ in a swamp or bog.

In a fourth study, Sheppard (1990) and Sheppard et al. (1991) discussed the plant uptake and soil transport of $\mathrm{C}-14$ labelled $\mathrm{CO}_{3}$ and $\mathrm{PCB}$ in soils with high and low retention. The basis for this study originate from data indicating that $\mathrm{C}-14$ is long lived and very mobile in either a dissolved or gaseous phase in both low- and high-level waste disposal. It is also very biologically active. 
This study was designed to develop concentration ratios of this nuclide in plants.

While lysimeters and intact soil cores were used for the studies, no sizes were given. It is assumed that they were small ( $\mathrm{cm}$ rather than $\mathrm{m}$ ). Both $\mathrm{CO}_{3}$ and $\mathrm{PCB}$ labeled with $\mathrm{C}-14$ were used as spikes at the surface and near the bottom of the soil cores with and without plants.

Results showed that $\mathrm{CO}_{3}$ could be completely lost and that PCB was mobile in the soil profile. In those soils with plants, there was a more rapid loss of $\mathrm{C}-14 \mathrm{CO}_{3}$ from the soil. There was a $2 \%$ retention of the initial inventory in a carbonate soil that followed first-order rate function loss.

It was found that the concentration ratios for PCB (0.014 to 0.09) were in line with the literature. Those for $\mathrm{CO}_{3}$ were about 25 -fold below the currently used value $(0.6$ to 1.5$)$. These values were considered by the experimentalist to be consistent in comparison to other radionuclides from year to year and crop to crop.

\section{Los Alamos National Laboratory}

A lysimeter test facility, the Experimental Engineered Test Facility (EETF), was developed at Los Alamos National Laboratory in 1981. The reported study was conducted at EETF and was jointly sponsored by DOE and NRC. The EETF consists of a cluster of six corrugated metal culverts, $3 \mathrm{~m}$ in diameter and $6 \mathrm{~m}$ deep, placed around a central instrument and access caisson of the same size. In five of the six interstitial vertical positions located between the lysimeters and the central access caisson, there are pipes $46 \mathrm{~cm}$ in diameter and $6 \mathrm{~m}$ long. The purpose of these pipes was not detailed. Access ports are horizontally situated at intervals $75 \mathrm{~cm}$ deep between the central caisson and each of the surrounding lysimeter caissons (Nyhan et al. 1986b).

Two of the studies that have been conducted at the EETF include a joint DOE/NRC field study of tracer migration in the unsaturated zone and a DOE field study of design of waste repositories at arid sites. The DOE/NRC study (started in 1984) was used to evaluate leaching and transport of solutes in a sandy silt backfill used for shallow land burial operations at Los Alamos. Movement in such material can be under saturated or unsaturated conditions. The purpose of the study was to provide data to develop a capability to predict chemical transport under unsaturated conditions. Lysimeter-scale studies rather than laboratoryscale studies were conducted because experiments performed on the larger scale are more representative of large-scale field problems than those performed with small columns (Nyhan et al. 1986a).

The lysimeter used in the study was filled with a crushed Bandelier tuff. Before the lysimeter was filled, the drain at the bottom of the vessel was covered with a coarse screen. Next, $0.25 \mathrm{~m}$ of $2-3 \mathrm{~cm}$ diameter gravel was placed over the screen followed by $0.25 \mathrm{~m}$ of coarse sand and the tuff. An injection system was then assembled to provide the necessary quantity of water containing the requisite tracer (Figure 36). Porous hollow fiber bundles (instead of moisture cups) were installed for the collection of soil water. These bundles consisted of hydrophilic fluoropolymer fibers $20 \mathrm{~cm}$ long. The assembled fiber bundles were fitted with a suitable length of $0.63-\mathrm{cm}$ polyethylene tubing and placed in a borehole within a plug of slurried tuff/silica flour.

Two types of tracer migration data were obtained. In the first one (the simplest case), measurements of water and tracer inflow and outflow rates provided data for mass balance calculations and determination of when steady-state water content and flow conditions were reached. Other data were derived from soil solution samples from the tuff in the lysimeter at various depths to determine tracer movement and dispersion rates as functions of time and depth (Polzer et al. 1986).

The study included both nonabsorbing tracers ( $\mathrm{I}$ and $\mathrm{Br}$ ) and sorbing tracers (Cs, Sr, Li). Six-day pulses of tracers were added under steady and unsteady flow conditions. In addition, a $0.01-\mathrm{N}$ calcium chloride solution was added throughout the experiments to maintain a constant ionic strength and proper moisture and flow conditions. To obtain data on tracer movement, samples of soil water were collected from the samplers that 


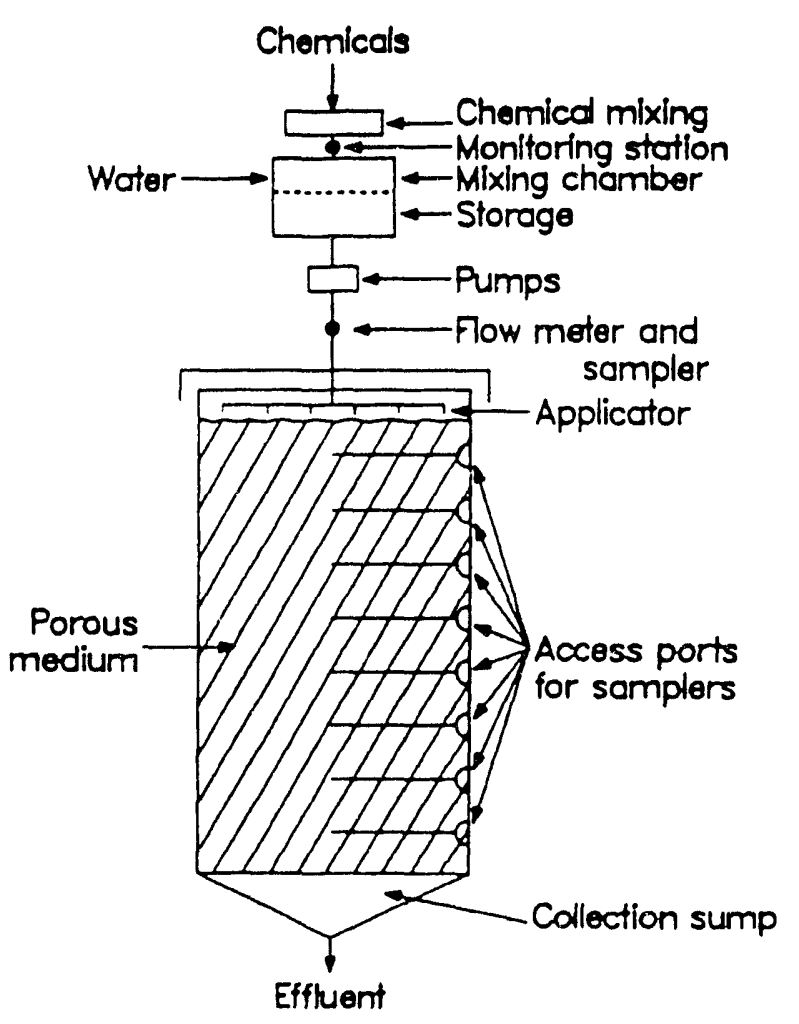

Figure 36. Diagram of Los Alamos National Laboratory lysimeter (Nyhan et al. 1986a).

had been placed at various depths within the lysimeter. In this way, the migration of the tracers through the tuff material could be studied as functions of depth and time. Data for each tracer were compared to those of the other tracers and the values were used to calculated effective dispersion coefficients.

Data obtained from the study (Polzer et al. 1986) indicated that under steady and unsteady unsaturated flow conditions, the nonabsorbing tracers ( $\mathrm{I}$ and $\mathrm{Br}$ ) were indistinguishable in their transport patterns. Lithium behaved similarly to these tracers, except some sorption did occur, which resulted in a minor degree of transport retardation. Spatial distribution of these three tracers appeared to be relatively uniform. However, $\mathrm{Cs}$ and $\mathrm{Sr}$ concentrations showed much more spatial variability. This difference in variability suggested that the tuff material was heterogeneous with respect to sorption sites (nonuniform sorption behavior of various mineral constituents). It was found that $\mathrm{Sr}$ and $\mathrm{Cs}$ had retarded movement, and moisture samples had to be taken at shallower depths $(43-118 \mathrm{~cm})$ because of their slower movement. The data for Sr transport indicated that most of the Sr had moved through these profiles before samples were obtained. However, the trailing end of the $\mathrm{Sr}$ breakthrough was observed between 88 and $118 \mathrm{~cm}$ deep.

It was generally observed that when the tuff material was allowed to drain, the concentration of tracers in the effluent solution tended to increase after influent flow was reestablished. The two phenomena thought to account for the increase were evaporation from the soil surface during drainage and diffusion of the tracers from immobile water to mobile water.

Another study using the lysimeter facility was designed to evaluate the ability of a capillary barrier to effectively convey water infiltrating a shallow land burial trench around and away from underlying buried wastes (known as a wick system) (Nyhan et al. 1986b). 


\section{WATER MOVEMENT STUDIES}

\section{Bioengineering Management Lysimeters}

Fundamental concepts that might prove useful for control of infiltration and percolation of water into disposed waste include three types of covers (O’Donnell et al. 1987): (a) resistive layer barrier (clay layer barrier), (b) conductive layer barrier (capillary barrier), and (c) bioengineering management (surface barrier).

Lysimeter studies at Maxey Flats and Beltsville, Maryland (sponsored by the NRC and operated by the NRC, the University of California, and the University of Maryland) are being used to evaluate the concept of bioengineering management as a technique to prevent movement of precipitation into areas of buried LLW. Large-scale $(22.9 \mathrm{~m} \times 1.3 .7 \mathrm{~m} \times 3.0 \mathrm{~m})$ field lysimeters are in use at Beltsville, Maryland, but the dimensions of the Maxey Flats lysimeters were not available (O’Donnell et al. 1987).

Bioengineering management utilizes a combination of engineered enhanced run-off and stressed vegetation in an overdraft condition to control deep water percolation through disposal unit covers. The concept is that vegetation planted between areas of an impermeable cover will intercept incoming solar energy and promote evapotranspiration. Roots that will extend under the cover in all directions will remove water from the soil. Such a system is similar to a supermarket parking lot where trees are planted in islands among an extensive paved area.

A representation of a Beltsville lysimeter is seen in Figure 37. Placement of the Beltsville lysimeters is seen in Figure 38 . Two of the six lysimeters are currently being used for bioengineering management studies, while the others are evaluating the effects of other various engineered

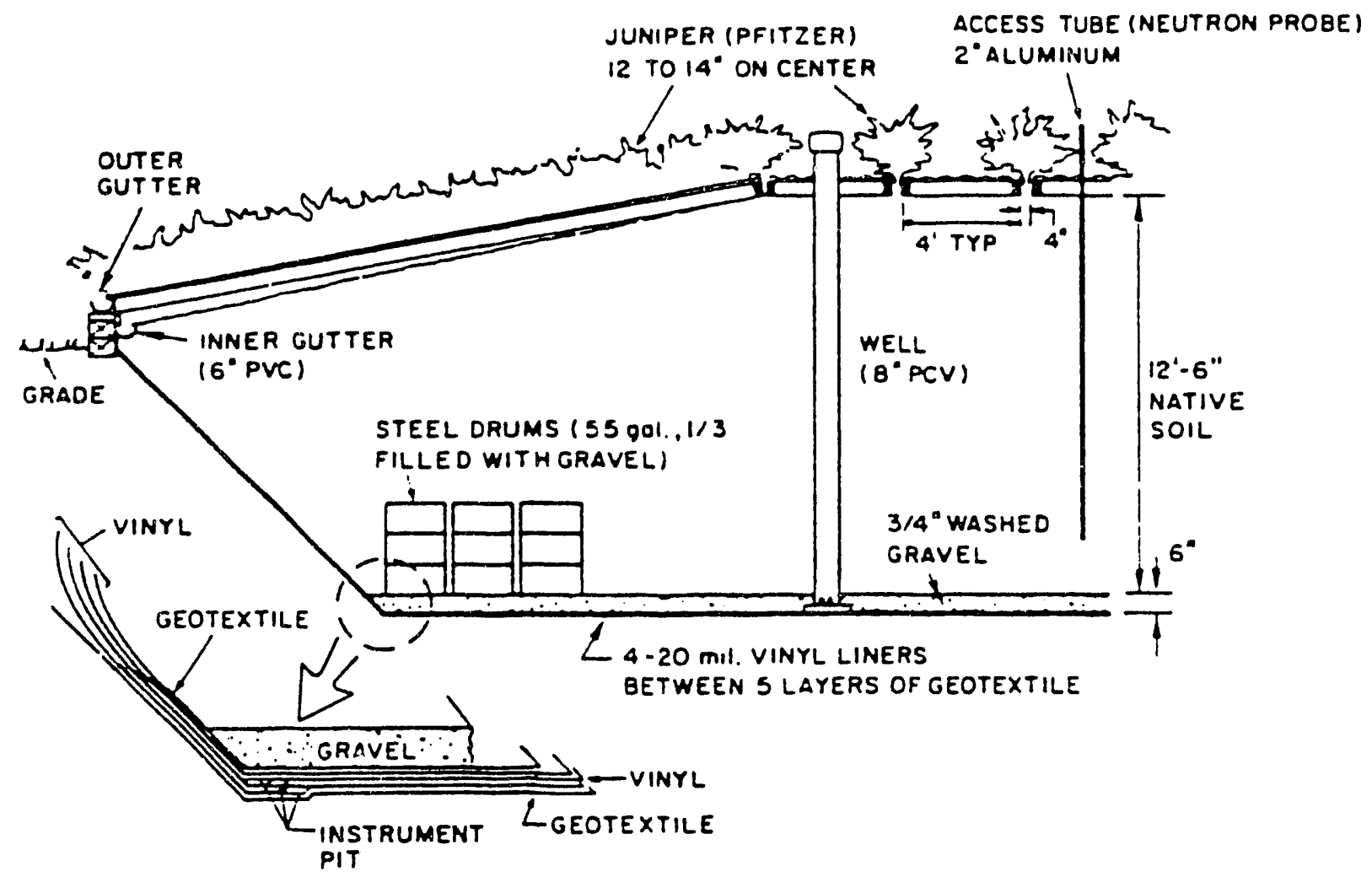

Figure 37. Diagram of Beltsville bioengineered lysimeter (O’Donnell et al. 1991). 


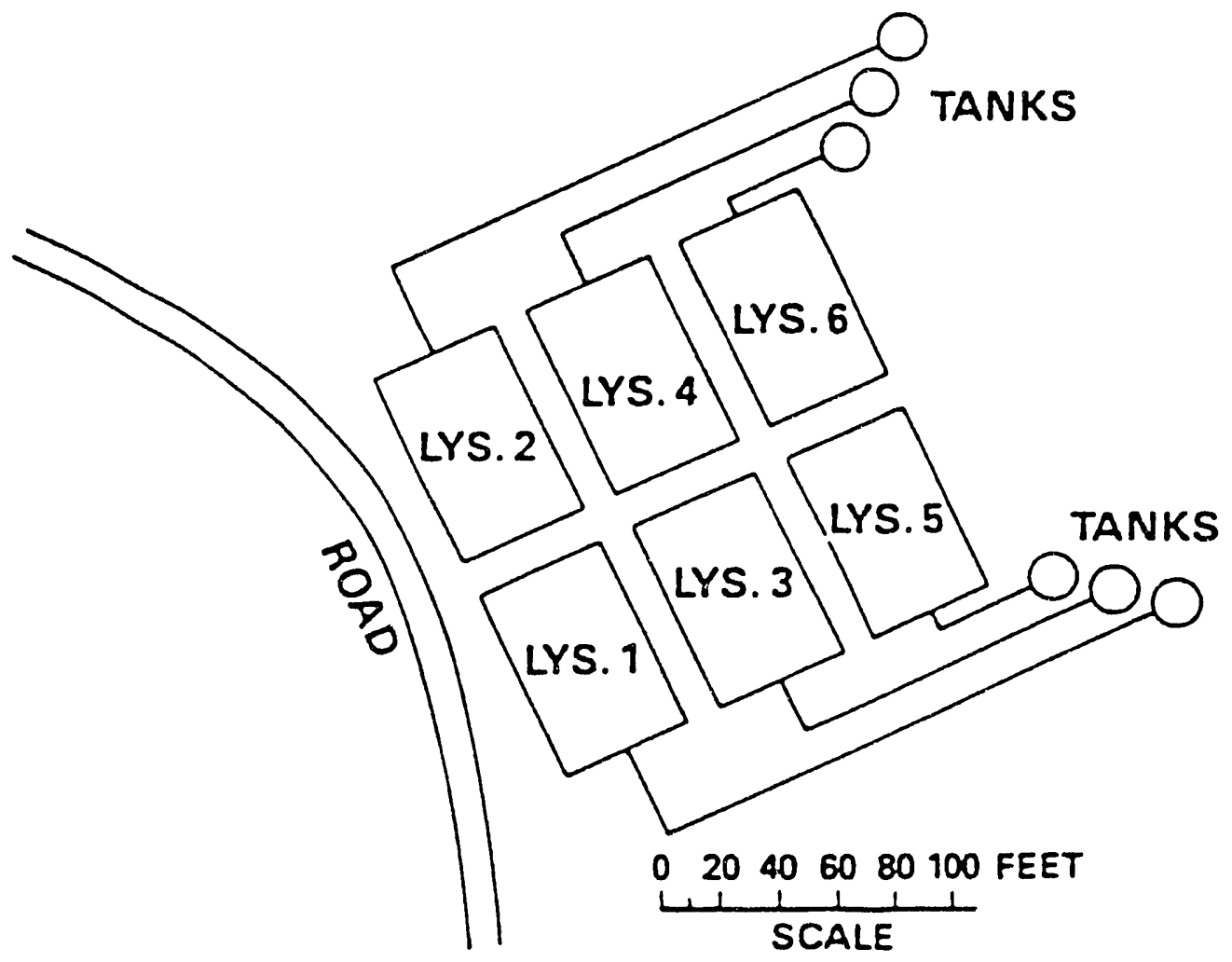

\begin{tabular}{cc} 
Date \\
Lysimeter & Completed \\
\hline
\end{tabular}

\begin{tabular}{llc}
1 & Bloenglneering management & $5 / 87$ \\
2 & Bloengineering management & $5 / 87$ \\
3 & Vegetated crowned soil cover & $5 / 87$ \\
4 & Rlp-Rap over resistive layer barrier & $10 / 88$ \\
5 & Resistive layer barrier over & $1 / 90$ \\
6 & Conductive layer barrier & $4 / 89$ \\
\hline
\end{tabular}

\section{Design type and completion dates of experimental lysimaters located at Beltsville, MD.}

Figure 38. Plan view showing placement of lysimeters at Beltsville (O'Donnell et al. 1991).

covers. Fill material for these lysimeters is isolated from the surrounding soil through the use of four layers of 20-mil PVC liners and five layers of geotextile (Figure 37).

Positive runoff from the bioengineered lysimeter surfaces is accomplished with corrugated panels. Junipers planted between the panels provide for eventual vegetative cover and root penetration to promote evapotranspiration to remove surface water (O’Donnell et al. 1991).

Initial investigations of the bioengineering management technique were carried out at the Maxey Flats site. In this operation, a complete water balance was maintained. Surface runoff was collected in a sump and pumped to a collection tank while deep percolation was measured by maintaining a constant water table level by 
pumping excess water to a storage tank. Surface evaporation and plant transpiration are then calculated by subtracting of the total surface runoff and deep percolation from the incoming precipitation. The difference is then considered to be evapotranspiration. Work at the Maxey Flats site ended in 1988.

Lysimeters used in the studies are designed to measure precipitation, surface runoff, percolation, and evapotranspiration. These data are used to calculate complete water balances for the systems.

\section{Hanford Site}

Precision-weighing lysimeters (Figure 39) were installed to measure variations in evapotranspiration for distinct plant communities at the Hanford Site (Gee 1987). This work was sponsored by DOE and developed jointly by PNL and Westinghouse Hanford Company. The facility is operated by PNL.

The monolith-lype lysimeters are arranged in pairs and are located on two adjacent sites, one

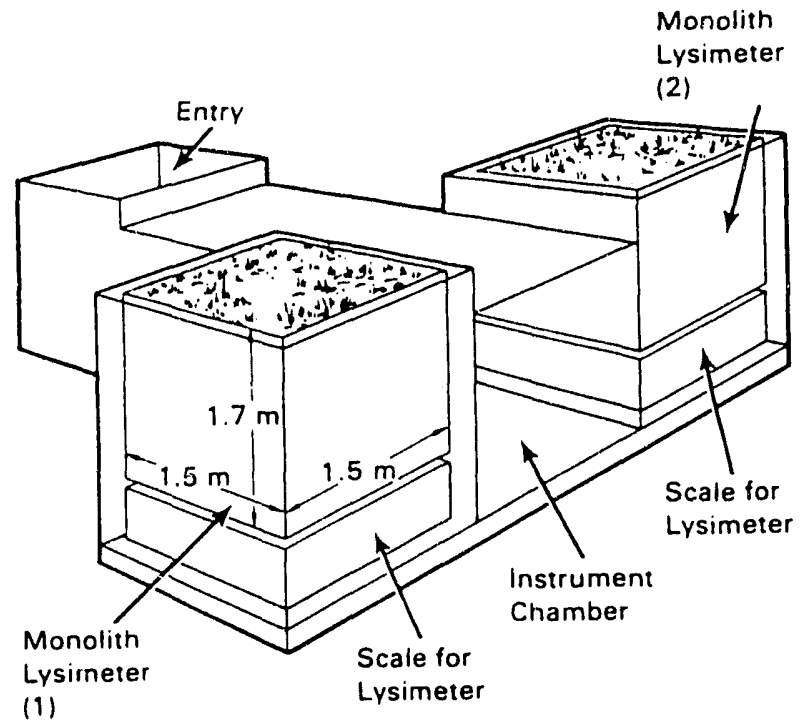

Figure 39. Diagram of precision weighting lysimeters for evapotranspiration measurements at Hanford's Arid Land Ecology Reserve (Gee 1987). dominated by bunchgrass and one dominated by sagebrush. Electronic scales are used to provide a continuous record of weight changes that represent water loss via evapotranspiration or water gain from precipitation. Each lysimeter weighs about 7 metric tons and consists of an undisturbed block (monolith) of soil $1.5 \mathrm{~m}$ on a side and $1.7 \mathrm{~m}$ deep. The intact soil monoliths were excavated and were then contained in an open-ended steel container that was dropped over the selected monolith. Two 20-ton hydraulic jacks attached to a flat steel plate were used to shear the bottom of the monolith. A specially constructed gantry was used to remove the monolith and place it on a soilfilled tray containing a network of ceramic moislure cups.

The data collection system includes monitoring instruments and radiotelemetric capability. Tensiometers and thermocouple phychrometers were placed at the 0.7 and $1.2-\mathrm{m}$ depths 10 monitor matrix and total water potential, respectively. The lysimeters are placed on platform scales that have $\mathrm{a} \pm 0.05-\mathrm{kg}\left( \pm 0.02-\mathrm{mm} \mathrm{H}_{2} \mathrm{O}\right)$ resolution. The scales are monitored with a CR7 data logger, and the data are transmitted $40 \mathrm{~km}$ via radiotelemetry to the laboratory for processing and display. Instrumentation for micrometeorological and energy budget data are incorporated with the data retrieval system.

Data from the lysimeter system are to be used to develop predictive models of the water-driven processes in arid regions. It is expected that such models will fill a critical role in the management of LLW and hazardous chemical wastes.

In addition to the above work, a field lysimeter test facility was constructed during FY 1987 at Hanford to test protective barriers for isolating LLW and hazardous wastes from the environment (Campbell and Gee 1990). The facility is sponsored by DOE and is operated by PNL. The purpose of the facility is to measure water balance within barriers as precipitation is partitioned into evaporation (including transpiration), storage, and drainage. It is known that water balance in protective barriers depends on the water-holding capacity of the soil, the gradient of a potential, and the conductivity of the underlying capillary 
barrier. The selected barrier was designed to use soil with a high water-storage capacity, and a capillary barrier underlying the soil was designed to increase its storage capacity. Increasing the water storage capacity is intended to hold water (which would normally drain) near the barrier surface for evaporation to the atmosphere.

A diagram of the field lysimeter test facility is shown in Figure 40. The facility contains 14 drainage lysimeters, four weighing lysimeters, and six clear tube lysimeters (four clear tube lysimeters were added in FY 199()). It is designed for placement below ground level with only the tops of the lysimeters protruding $0.05 \mathrm{~m}$ above the surface of the soil. Various barrier configurations being evaluated consist of a textural break between $1.0 \mathrm{~m}$ of a $1.5-\mathrm{m}$ layer of silt loam soil and a $0.05-\mathrm{m}$ layer of washed, No. 20-30 sand. Treatments include three levels of water applications (artificial precipitation), two soil profile depths, two vegetative cover conditions, and two surface armor treatments. A variety of 11 species of vegetation has been transplanted into selected lysimeters (Figure 41). Seven experimental treatments have been applied to the barrier material in the lysimeters to demonstrate the main influences on barrier performance (Figure 42).

Each of the drainage lysimeters (see Figure 43) is a steel cylinder with a $0.95-\mathrm{cm}$ wall, $2 \mathrm{~m}$ in diameter and $3 \mathrm{~m}$ deep, with the top half $(1.5 \mathrm{~m}$ or $1.0 \mathrm{~m}$ ) filled with soil and the bottom half filled with a filterbed and riprap. These lysimeters contain silt loam (1.0 to $1.5 \mathrm{~m}$ deep), a No. 20-30 sand layer that is $0.05 \mathrm{~m}$ deep, and a filterbed graded from No. 8 sand through rock $0.1 \mathrm{~m}$ in diameter to basalt riprap $0.15 \mathrm{~m}$ in diameter. The lysimeters are arranged on each side of an access/ instrument tunnel. They have a sloping floor and stoppered drain hose to allow draining water to be collected. Intimate contact with the soil is mainlained with the half of the lysimeter that faces out from the tunnel while the tunnel side is

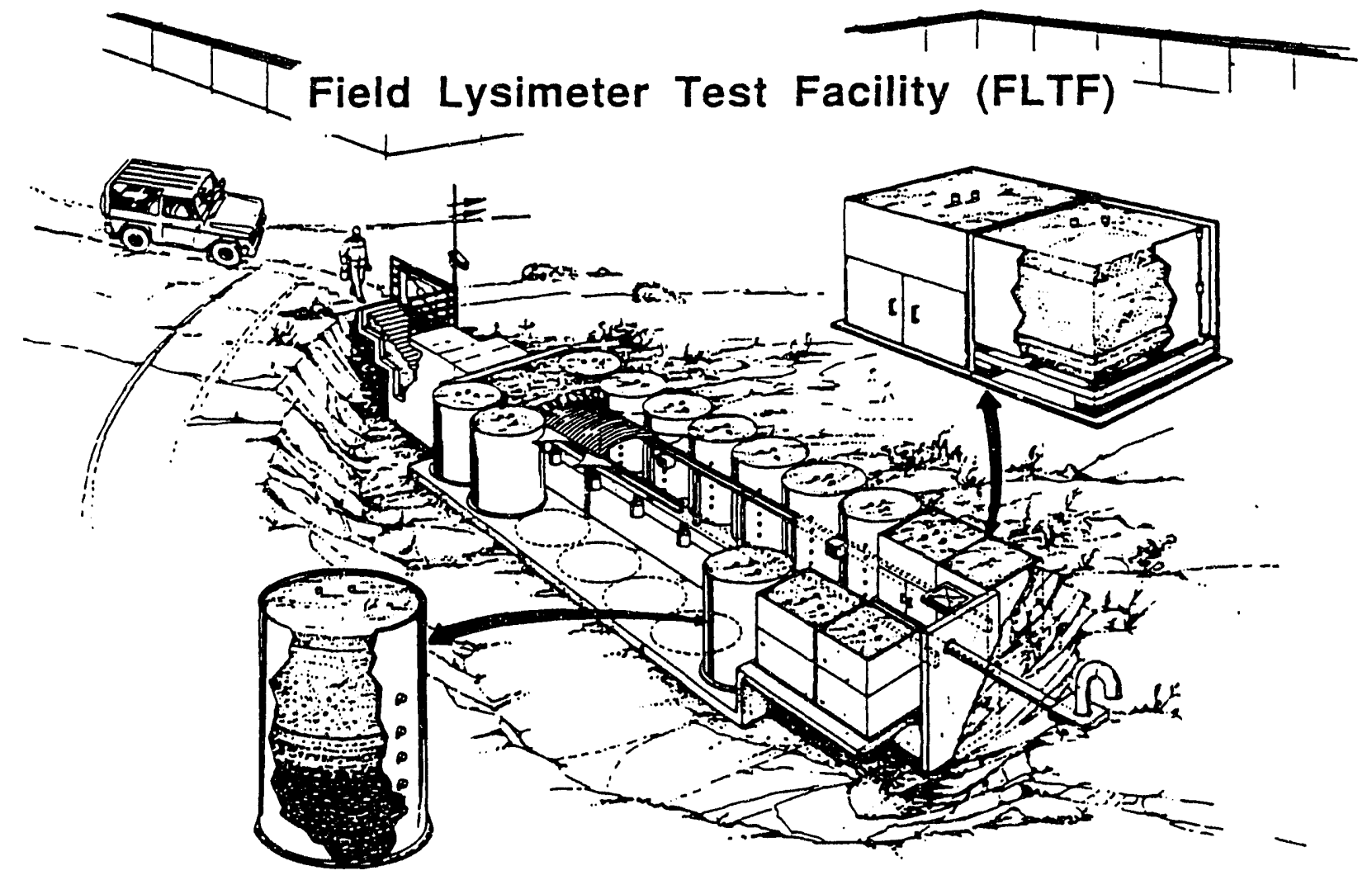

Figure 40. Diagran of Field Lysimeter Test Facility at Hanford (Campbell and Gee 100), 


\section{Water Movement Studies}

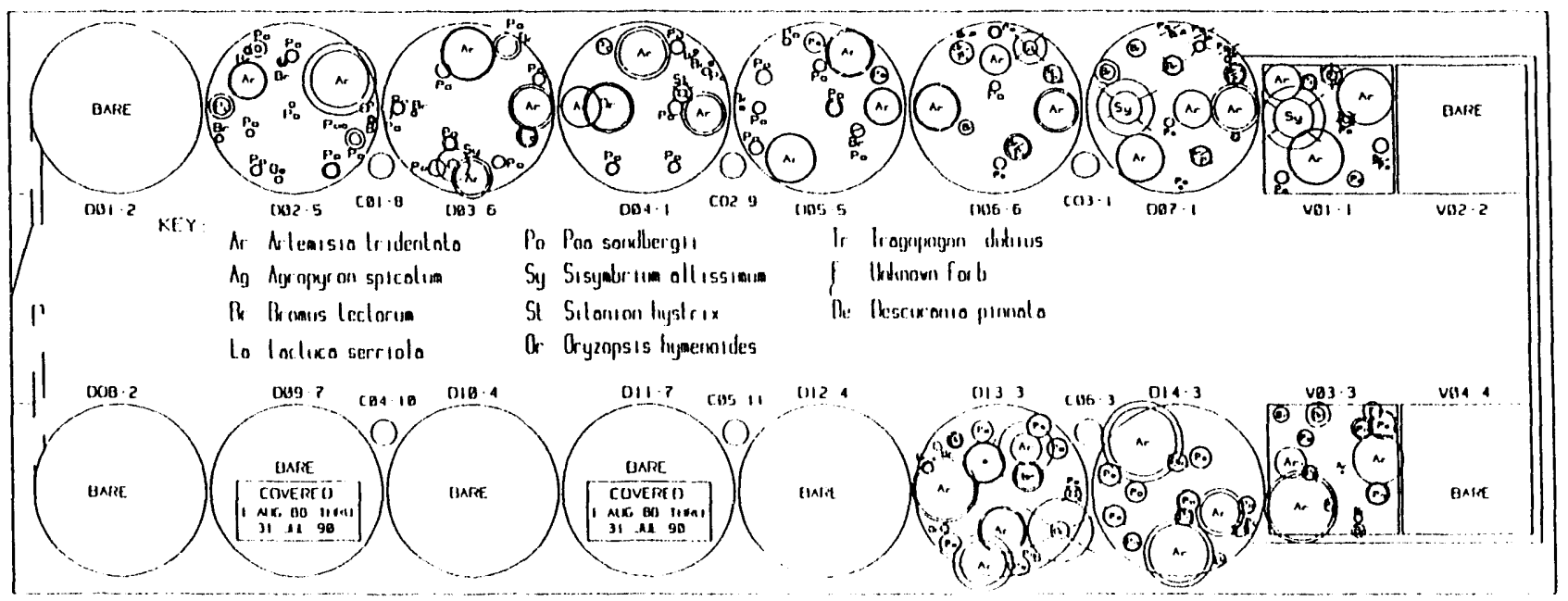

Figure 41. Diagram of lysimeter placement and vegetation cover at the Field Lysimeter Test Facility (Campbell and Gee 1990).

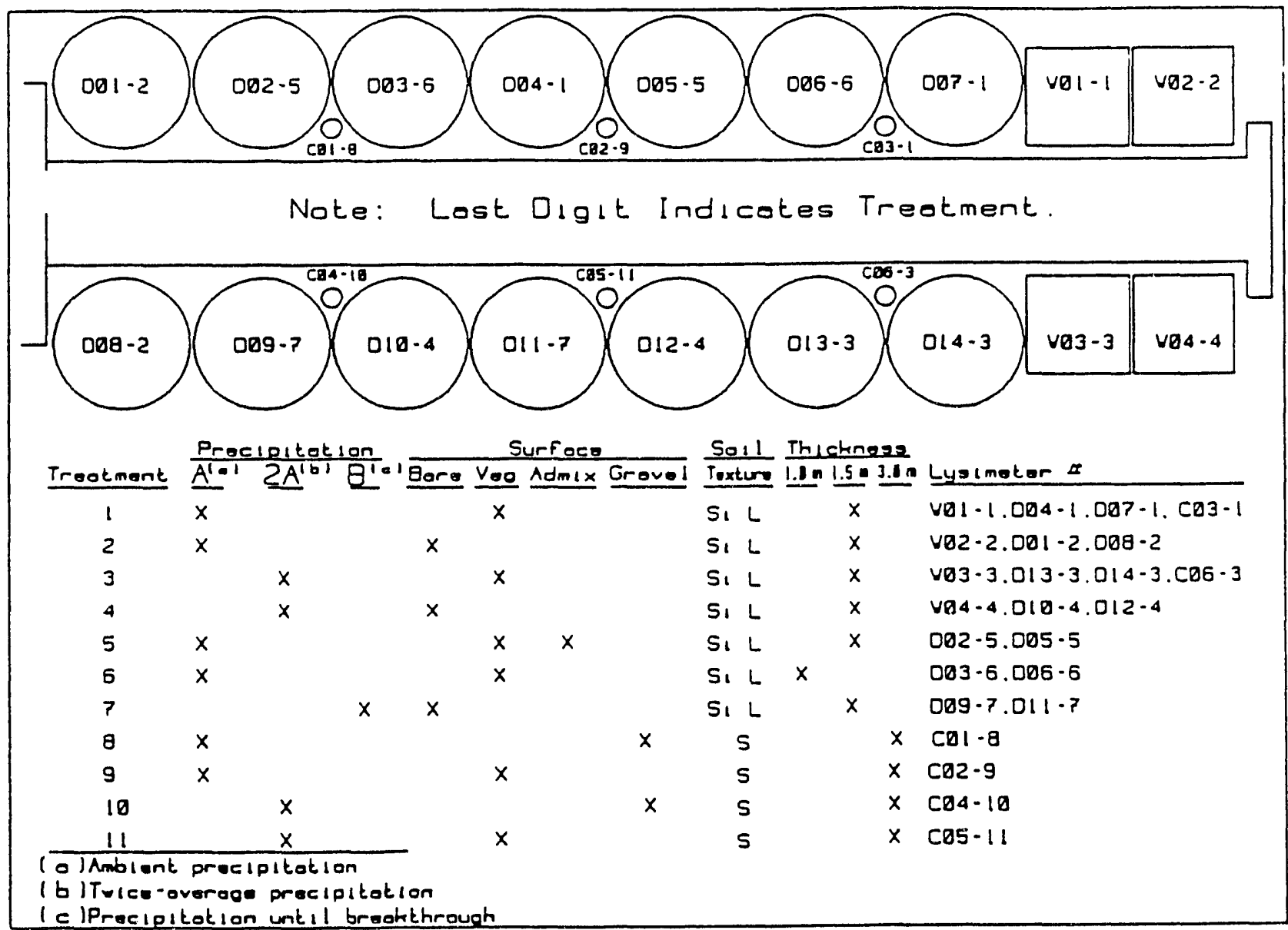

Figure 42. Plan view of the Field Lysimeter Test Facility with treatment designations (Campbell and Gee 1990). 


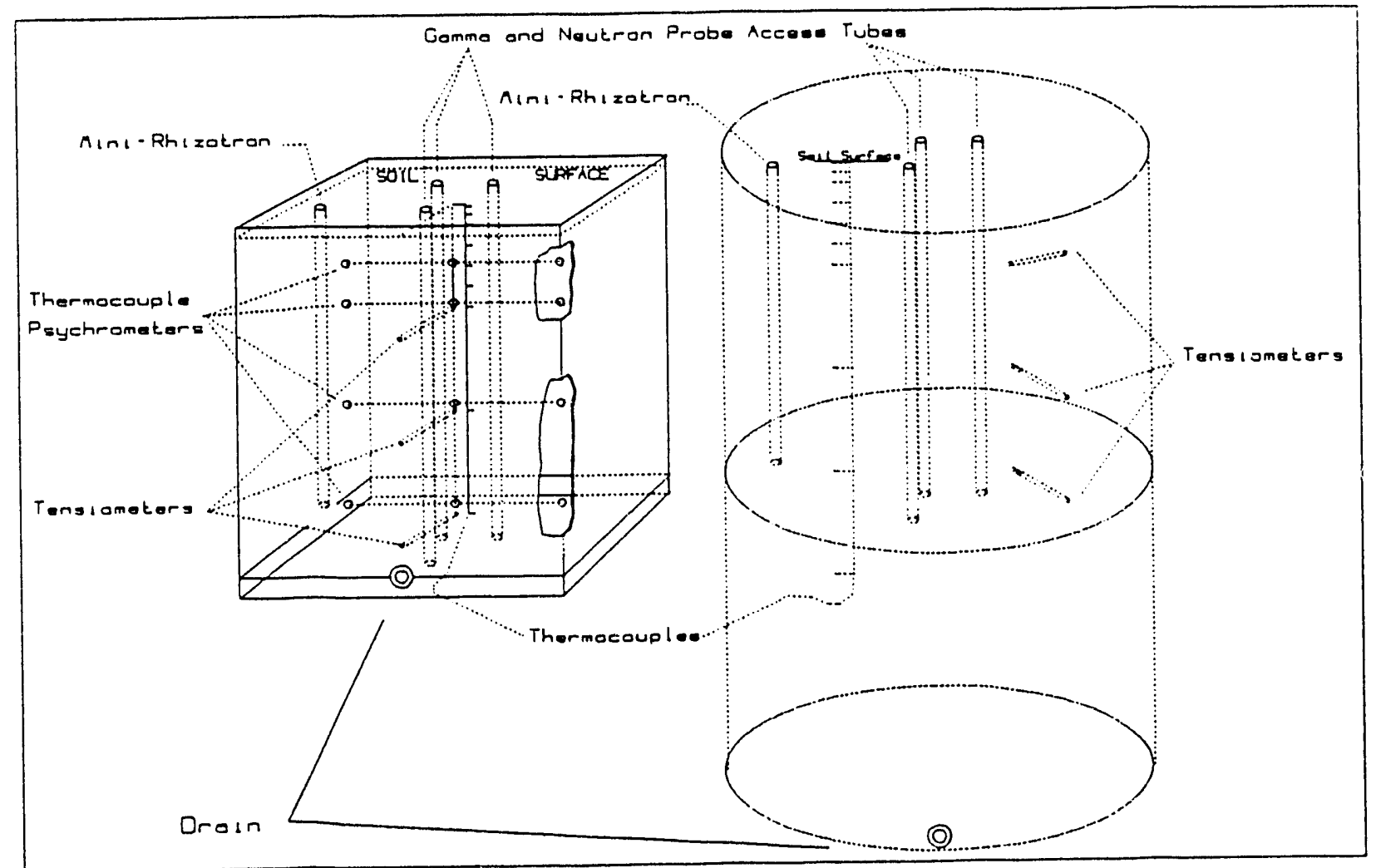

Figure 43. Diagram of instrument location in Field Lysimeter Test Facility lysimeters (Campbell and Gee 1990).

insulated to help preserve the natural temperature regimes.

The weighing lysimeters are boxes $1.5 \mathrm{~m} \times 1.5 \mathrm{~m} \times 1.7 \mathrm{~m}$ boxes. Each contains a $0.05-\mathrm{m}$ sand filterbed and is filled with soil. The full box rests on a 9,000-kg capacity platform scale. Weight is recorded every 20 seconds on a data logger. The bottom of the box is slopping and contains a drain port at the low point. These lysimeters are not in contact with soil nor are they insulated. They contain instrumentation to monitor water content, water potential, soil temperature, and root distribution.

Six clear-tube lysimeters are used for visual water and root observations. They are made from $1.83-\mathrm{m}$ sections of cast acrylic plastic. These sections are $0.3 \mathrm{~m}$ in diameter with a $0.0063-\mathrm{m}$ wall thickness and are $3 \mathrm{~m}$ long.
Data collected from the field lysimeter test facility include air temperature, net radiation, wind speed, relative humidity, precipitation, soil water content and distribution, soil moisture tension, soil temperatures, evaporation, drainage, and potential runoff. Data from the first five items listed above are measured hourly and transported via phone to a laboratory for processing. Soil water content and distribution are calculated from water storage data (as determined by changes in lysimeter weight) and from data calculated from neutron probe measurements at various soil depths. Soil moisture tension was determined from data obtained from tensiometers and thermocouple psychrometers. The use of these two types of devices allowed measurement over a wide range of moisture tensions ( 0 to $-0.075 \mathrm{MPa}$, tensiometer; -0.05 to $-8 \mathrm{MPa}$, thermocouple psychrometer). Soil temperature was measured by thermocouples. 
The data are used to developed a water budget for each lysimeter that accounts for precipitation. evaporation, (including transpiration), storage. and drainage. The budget is dependent on the driving forces of temperatures and tensions acting within the lysimeter and on solar radiation, wind. humidity, and temperatures acting at the soil surface. Reported results show that the use of a capillary barrier increased water storage an average of $10.5 \mathrm{vol} \%$. The increased storage has heen sufficient to hold the average annual precipitation at the site. Over an annual cycle. evaporation alone from the bare soil surfaces removed enough water from the soil to prevent downward movement of water.

\section{New Mexico State University}

A comprehensive field trench study was conducted in semiarid southern New Mexico to provide data to test delerministic and stochastic models of vadose zone flow and transport (Wierenga et al. 1991). The work was sponsored by the NRC and EPA and was conducted at New Mexico State University near Lals Cruces.

In this study, actual containment of soil in lysimeters wals not used. Rather, a trench $26.4 \mathrm{~m}$ long, $4.8 \mathrm{~m}$ wide, and $6.0 \mathrm{~m}$ deep was constructed in undisturbed soil to provide horizontal aceess to an irrigated plot. An area $4 \mathrm{~m}$ by $9 \mathrm{~m}$ on the south side of the trench was selected for controlled application of water containing a tracer (Figure 44). A total of 18 vertical neutron access tubes were installed, penetrating down $106.1 \mathrm{~m}$, on the area adjacent to the south wall of the trench and were used to monitor water content. Five additional vertical neutron access tubes were installed, which penetrated to $1.5 \mathrm{~m}$. Neutron probe access tubes were installed before excavation of the trench. Probe readings were initially laken once a day, but less frequently outside the wetted area and during the redistribution phase.

Tensiometers were installed through the trench face so that the porous cup of each tensiometer

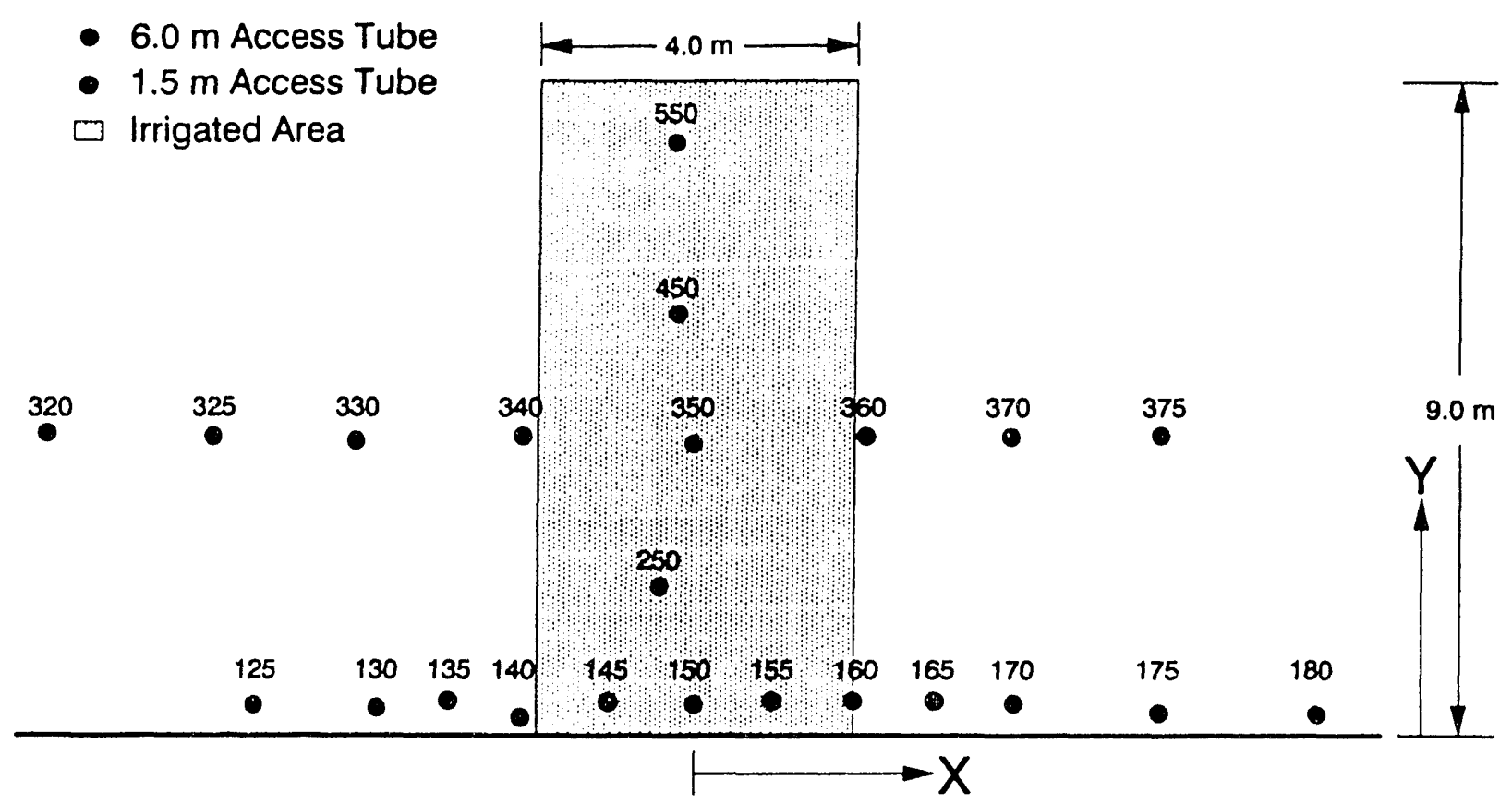

\section{Trench}

Figure 44. Plan view of trench lysimeter face with irrigated area and neutron probe access tubes (Wierenga et a! 1901). 
was inserted $50 \mathrm{~cm}$ horizontally into the formation. Tension in each tensiometer was measured daily with a hand-held pressure transducer.

The advance of a wetting front was determined from neutron probe data and from the tensiometer data as well as being monitored on the trench face by visual observation. Soil solution samplers were installed in the trench face to obtain samples of the wetting front.

Results obtained by comparing field data with those provided by one-dimensional flow models indicate that simple models give adequate predictions of the overall movement of the wetting front through the soil during infiltration. However, it was found that models give poor predictions of point values for water content due to the spatial variability of the soil.

Following this initial study, an area $1.2 \mathrm{~m}$ wide and $12 \mathrm{~m}$ long on the north side of the trench was irrigated with water containing tracers using drip irrigation system (Hills et al. 1991). As with the previous area, this area was heavily instrumented with tensiometers and with neutron probe access tubes to monitor water movement and soil moisture cups for solute sampling.

Comparisons between measurements and predictions made with a two-dimensional model showed qualitative agreement for two of the three water content measurement planes. Model predictions of tritium and bromide transport were not as satisfactory. While the simple deterministic model did show larger downward motions for bromide than tritium during redistribution, it did not predict the high concentrations of solute observed during infiltration, nor did it predict the heterogeneous behavior observed for tritium during infiltration and for bromide during redistribution. 


\section{CONCLUSIONS}

Review of lysimeter design and application has shown that lysinceters are very useful tools that have been successfully applied by many acarricess to the study of radionuclide movement in "sils under actual environmental conditions. In all the reviewed studies, it was noted that the sponsors of lysimeter studies generally do not appreciate that lysimeter studies require a long-term commitment in terms of operational longevity and funding. However, it was also determined that lysimeter use results in the acquisition of hard-to-obtain radionuclide transport data in a cost-efiective manner. Such information cannot be obtained from artificially "iselerated laboratory studies.

Existing NRC lysir.teter studies developed and managed by tin INEL are utilizing technologies similar to those used by other successful experiments such as the PNL and SRS special waste form lysineters. Also, data from existing NRC radionuclid transport lysimeter experiments are being applied to waste form performance assessments, thus moving the project from observational to predictive. Fow existing experiments utilize wastes from comme ricial power stations. In addition, the important long-lived radionuclides listed in Table I of I) CFR 61 have been seriously investigated hy only a few researchers.

Information oblained from this review has been use 1 to plan new lysimeter studies so as to maximize the usefulness of the data. The Phase 2 lysimeter studies being planned by the NRC will incorporate features of the most successful existing experiments plus new technology. Such fealures presently planned for the Phase 2 experiment include the following:
- Using the natural environment of low-level waste dispo:al facilities, including precipitation

- Using small-scaled waste forms containing actual radioactive wastes rather than tracers

- Collecting leachate after it passes through the soil column by providing a separate leachate collector compartment, which is integrated to the lysimeter vessel

- Using porous cup soil-water samplers to collect soil water at various distances from the waste form

- Positioning porous cups near waste forms

- Using neutron probe and gravimetric measurements of soil moisture to supplement continuous electronic soil moisture probe measurements

- Providing adequate interface between the soil column and the leachate colluctor to allow for the free movement of water to the leachate collector

- Providing water-tight, corrosion-resistant lysimeter vessels to eliminate in/out leakage of water to the soil column, to reduce soil/ vessel chemical interactions, and to contain radionuclides within the exneriment

- Analyzing leachate samples for all radionuclides present in the waste form

- Analyzing leachate samples for radionuclide cheirl, "al complexes

- Utilizing field lysimeters in validate laboratory studies. 


\section{REFERENCES}

Campbell, M. D. and G. W. Gee, 1990, Field Lysimeter Test Facility: Protective Barrier Test Results (FY 1990, The Third Year), PNL-7558, Pacific Northwest Laboratory, Richland, WA.

Clapp, R. B., C. W. Francis, J. E. Cline, and L. S. Jones, 1988, "A Field Lysimeter Demonstration to Evaluate Land Burial of Wastes Containing Depleted Uranium," Procecedings of the 1988 DOE Model Conference, October 3-7, 1988. Oak Ridge National Laboratory, Oak Ridge, TN, CONF-881054. Vol. 2.

Colombo, P., M. Fuhrmann, R. Doty, and E. M. Franz, 1986, Special Waste Form-Arid Program Waste Form Acquisition and Laboratory Leaching Studies, BNL-37620, Brookhaven National Laboratory, Upton, N\%.

Criscenti, L. J. and R. J. Serne, 1987, Geochemical Analysis of Leachates from Cement/Lon'-Le'el Radioactive Waste/Soil Systems, PNL-6544, Pacific Northwest Laboratory, Richland, WA.

Gates, D. D., C. W. Francis, L. M. Laster, and R. R. Kimmitt, 1993, "Pilot and Field-Scale Uranium Lysimeter Studies at the Oak Ridge Y-12 Plant," Proceedings of the Materials Research Society Symposium, Scientific Basis for Nuclear Waste Management XVI, Boston, MA, November 30-December 4. 1992, Vol. 294, C. G. Interrante and R. T. Pabalan (eds.), pp. 865-870.

Gee, G. W., 1987, "Installation of Precision-Weighing Lysimeters for Evapotranspiration Measurements at Hanford's Arid Land Ecology Reserve," Pacific Northw'est Laboratory Ammual Report for 1985 to the DOE Office of Energy Research. Part 2, Environmental Sciences, PNL-6100, September.

Hills, R. G., P. J. Wierenga, D. B. Hudson, and M. R. Kirkland, 1991, "The Second Las Cruces Trench Experiment: Experimental Results and Two-Dimensional Flow Predictions," Water Resource's Res.. Vol. 27. pp. 2707-18.

Hooker, R. L. and R. W. Root, Jr., 1981, Lysimeter Tests of SRS Waste Forms, DP-1591, Savannah River Site, Aiken, SC.

1sherwood, D., 1981, Geoscience Data Base Handbook for Modeling a Nuclear Waste Repository. NUREG/CR-(0912, Vol. 1, Lawrence Livermore Laboratory, Livermore, CA.

Jones, T. L., R. J. Serne, and A. P. Toste. 1988, Special Waste Form Lysimeters, Arid: Three Year Monitoring Report, PNL-6400, Pacific Northwest Laboratory, Richland, WA.

McConnell, Jr., J. W., R. D. Rogers, E. C. Davis, and J. D. Jastrow, 1990a, TMI-2 EPICOR-II Resin/Line" Investigation: Low'Level Waste Data Base Development Program for Fiscal Year 1989, NUREG/CR-5229, Vol. 2, Idaho National Engineering Laboratory, EG\&G Idaho, Inc., Idaho Falls, ID.

McConnell, Jr., J. W., R. D. Rogers, D. A. Johnson, J. D. Jastrow, and D. S. Wickliff, 1990b, EPICOR-II Resin/Liner Investigation: Low-Level Waste Data Base Development Program for Fiscal Year 1990, NUREG/CR-5229, Vol. 3, Idaho National Engineering Laboratory, EG\&G Idaho, Inc., Idaho Falls, ID.

McConnell, Jr., J. W., R. D. Rogers, J. D. Jastrow, D. S. Wickliff, and R. R. Brey, 1992a, Field Lysimeter Investigations: Lon'Level Waste Data Base Development Program for Fiscal Year 1991, NUREG/CR-5229, Vol. 4, Idaho National Engineering Laboratory, EG\&G Idaho, Inc., Idaho Falls, ID, January. 


\section{References}

McConnell, Jr., J. W., R. R. Brey, T. M. Sullivan, and R. D. Rogers, 1992b, "Evaluation of EPICOR-II Resin/Liner Lysimeter Investigation Data Using 'MIXBATH,' a One-Dimensional Transport Code," Proceedings of Waste Management' '92, Tiucsom, AZ, March 1-5, 1992, Vol. 2 pp. 1551-5.

McConnell, Jr., J. W., R. D. Rogers, J. D. Jastrow, D. S. Wickliff, and T. M. Sullivan, 1993, Field Lysimeter In'estigations: Lon'Le'el Waste Data Base Development Program for Fiscal Year 1992, NUREG/CR-5229, Vol. 5, Idaho National Engineering Laboratory, EG\&G Idaho, Inc., Idaho Falls, ID, January.

MeIntyre, P. F., 1987. 1987 Monitoring Report for the Defense Waste Lysimeters, SRS Report DPST-87-568, Savannah River Site, Aiken, SC.

McIntyre, P. F. and R. H. Hawkins, 1987. 1987 Monitoring Report of Special Waste Form Lysimeters-Humid Site, Savannah River Site, Aiken, SC.

McIntyre, P. F., S. B. Oblath, and E. L. Wilhite, 1989, "Large-Scale Demonstration of Low-Level Waste Solidification in Saltstone," Emvironmental Asperts of Stabilization and Solidification of Hazardous and Radionetive Wastes, Cote and Gilliam (eds), ASTM STP 1033, Philadelphia, PA.

Neilson,Jr., R. M. and J. W. McConnell, Jr., 1986, EPICOR-II Re'sin Waste Form Testing, NUREG/CR-46.37, EGG-24.57, Idaho National Engineering Laboratory, EG\&G Idaho, Inc., Idaho Falls, ID.

Neilson, Jr., R. M., P. D. Kalb, and P. Colomoo, 1982, Lysimeter Study of Commercial Reactor Waste Forms: Waste Form Acquisition. Characterization, and Full-Scale Leaching, BNL-51613, Brookhaven National Laboratory, Upton, NY.

Nyhan, J., W. Polzer, E. Essington, E. Cokal, L. Lane, E. Lopez, E. Stallings, and R. Walker, 1986a, A Joint DOE/NRC Field Study' of Tracer Migration in the Unsaturated Zone, LA-10575-MS, Los Alamos National Laboratory, Los Alamos, NM.

Nyhan, J., W. Abeele, T. Hakonson, and E. A. Lopez, 1986b, Technology Development for the Design of Waste Repositories at Arid Sites: Field Studies of Biointrusion and Capillary Barriers, LA-10574-MS, Los Alamos National Laboratory, Los Alamos, NM.

O’Donnell. E. and J. Lambert, 1989, Low'Level Radioactive WAste Research Program Plan, NUREG/CR-1380, U.S. Nuclear Regulatory Commission, Rockville, MD.

O'Donnell, E., R. K. Schulz, and R. W. Ridky, 1987, "Control of Water Infiltration Into Near Surface LLW Disposal Units," Proceedings of the DOE Oak Ridge Model Conference, October 1.3-16, 1987, Oak Ridge, TN, CONF-871075, Vol. 1., Part 3, pp. 355-384.

O’Donnell, E., R. W. Ridky, and R. K. Schulz, 1991, "Control of Water Infiltration Into Near Surface LLW Disposal Units-Progress Report on Field Experiments at a Humid Region Site, Beltsville, Maryland," Proceedings of Waste Management '91, Tucson, AZ.

Oblath, S. B. and M. W. Grant, 1985, 1985 Monitoring Report for the Defense Waste Lysimeters, DP-85-893, Savannah River Site, Aiken, SC.

Polzer, W. L., E. H. Essington, H. R. Fuentes, and J. W. Nyhan, 1986, Compilation of Field-Scale Caisson Data on Solute Transport in the Unsaturated Zone, NUREG/CR-4720, Los Alamos National Laboratory, Los Alamos, NM. 


\section{References}

Rogers, R. D., J. W. McConnell, Jr., E. C. Davis, and M. W. Findley, 1986, Field Testing of Waste Forms Containing EPICOR-I/ Ion-Exchange Resins Using Lysimeters, NUREG/CR-4498, EG\&G-2438, Idaho National Engineering Laboratory, EG\&G Idaho, Inc., Idaho Falls, ID, June.

Rogers, V. and C. Hang (developers), 1987, "PATHRAE-EPA: A Low-Level Radioactive Waste Environmental Transport and Risk Assessment Code," EPA 520/1-87-028, December.

Sheppard, M. I., T. T. Vandergraat, D. H. Thibault, and J. A. K. Reid, 1983, "Technetium and Uranium: Sorption by Plan Uptake from Peat and Sand," Health Physics, 44, pp. 635-643.

Sheppard, M. I. and S. C. Sheppard, 1984, "Technetium Behavior in Soils of the Canadian Precambrian Shield," Proceedings from Technetium in the Environment, Cadarache, France, October 23-26, 1984, U.S. DOE, pp. $131-141$.

Sheppard, S. C., 1990, "Plant Uptake and Soil Transport of C-14 $\mathrm{CO}_{3}$ and C-14-labeled PCB in Soils of High and Low Retention," Proceedings from the Electric Power Research Institute Radioactive Waste Seminar; Boulder CO, August 9-10, 1990.

Sheppard, M. I., S. C. Sheppard, and B. D. Amiro, 1991, "Mobility and Plant Uptake of Inorganic C-14 and C-14-labeled PCB in Soils of High and Low Retardation," Health Physics, 61, pp. 481-92.

Sullivan, T. M., 1991, Selection of Models to Calculate the LLW Source Term. NUREG/CR-5773, Brookhaven National Laboratory, Upton, NY, October.

Sullivan, T. M., 1993, DUST Disposal Unit Source Term: Data Input Guide, NUREG/CR-6041, Brookhaven National Laboratory, Upton, NY.

Sullivan, T. M. and C. J. Suen, 1989, Low'Lev'el Waste Shallow'Land Disposal Source Term Model: Data Input Guides, NUREG/CR-5387, Brookhaven National Laboratory, Upton, NY.

Sullivan, T. M. and C. J. Suen, 1991, Low'Level Waste Source Term Model Development and Testing, NUREG/CR-5681, Brookhaven National Laboratory, Upton, NY.

Wierenga, P. J., R. G. Hills, and D. B. Hudson, 1991, "The Las Cruces Trench Site: Characterization, Experimental Results, and One-Dimensional Flow Predictions," Water Resources Res., Vol. 27. pp. 2695-2705. 

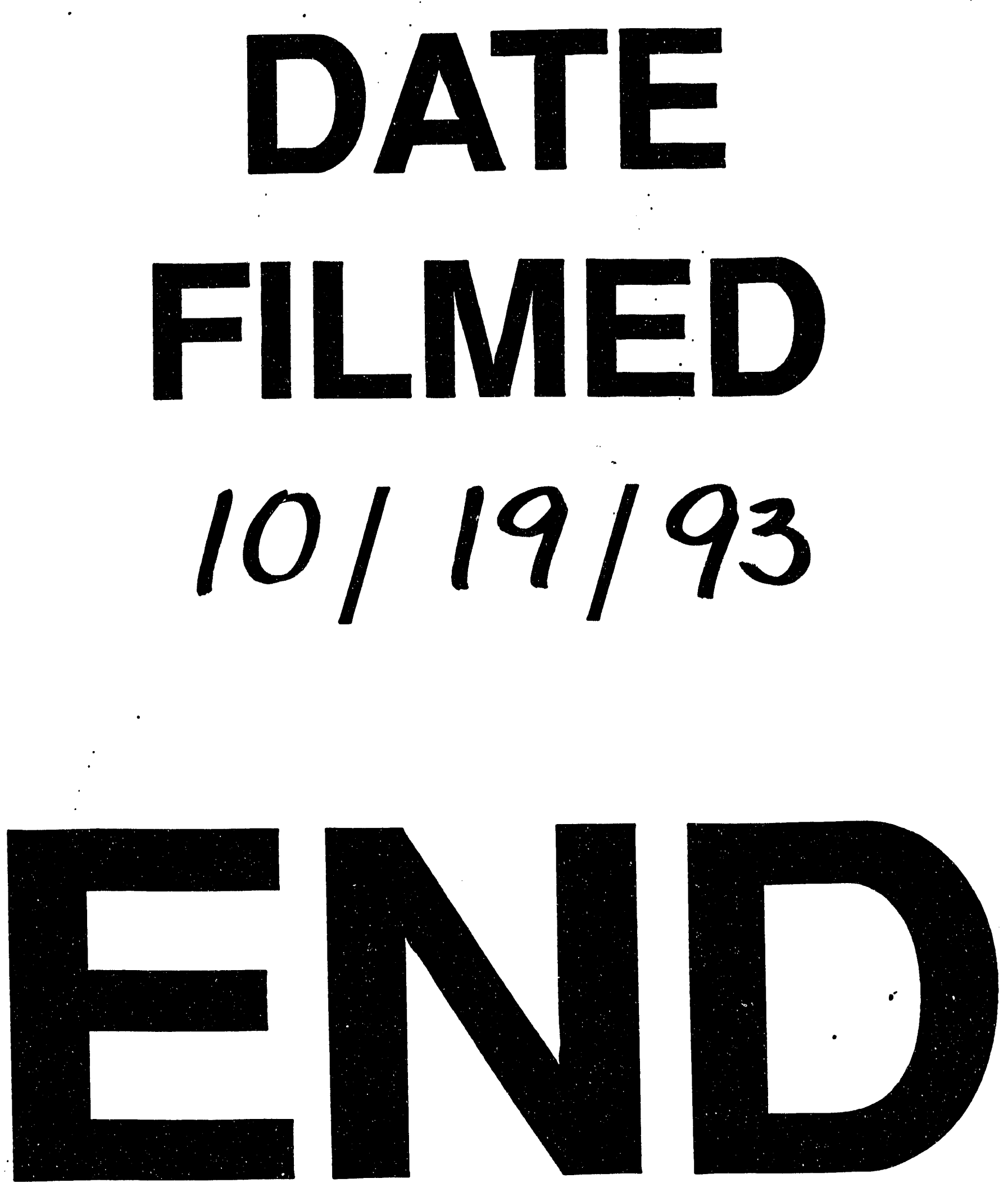
